\begin{tabular}{l|l} 
2. To: (Receiving Organization) & $\begin{array}{l}\text { 3. From: (Originating Organization) } \\
\text { Process Design }\end{array}$ \\
\hline 5. Proj./Prog./Dept./Div.: & 6. Cog. Engr.: \\
TWRS & T. W. Crawford H5-49
\end{tabular}

8. Originator Remarks:

\section{Approval/Release}

11. Receiver Remarks:

\section{EDT 608741}

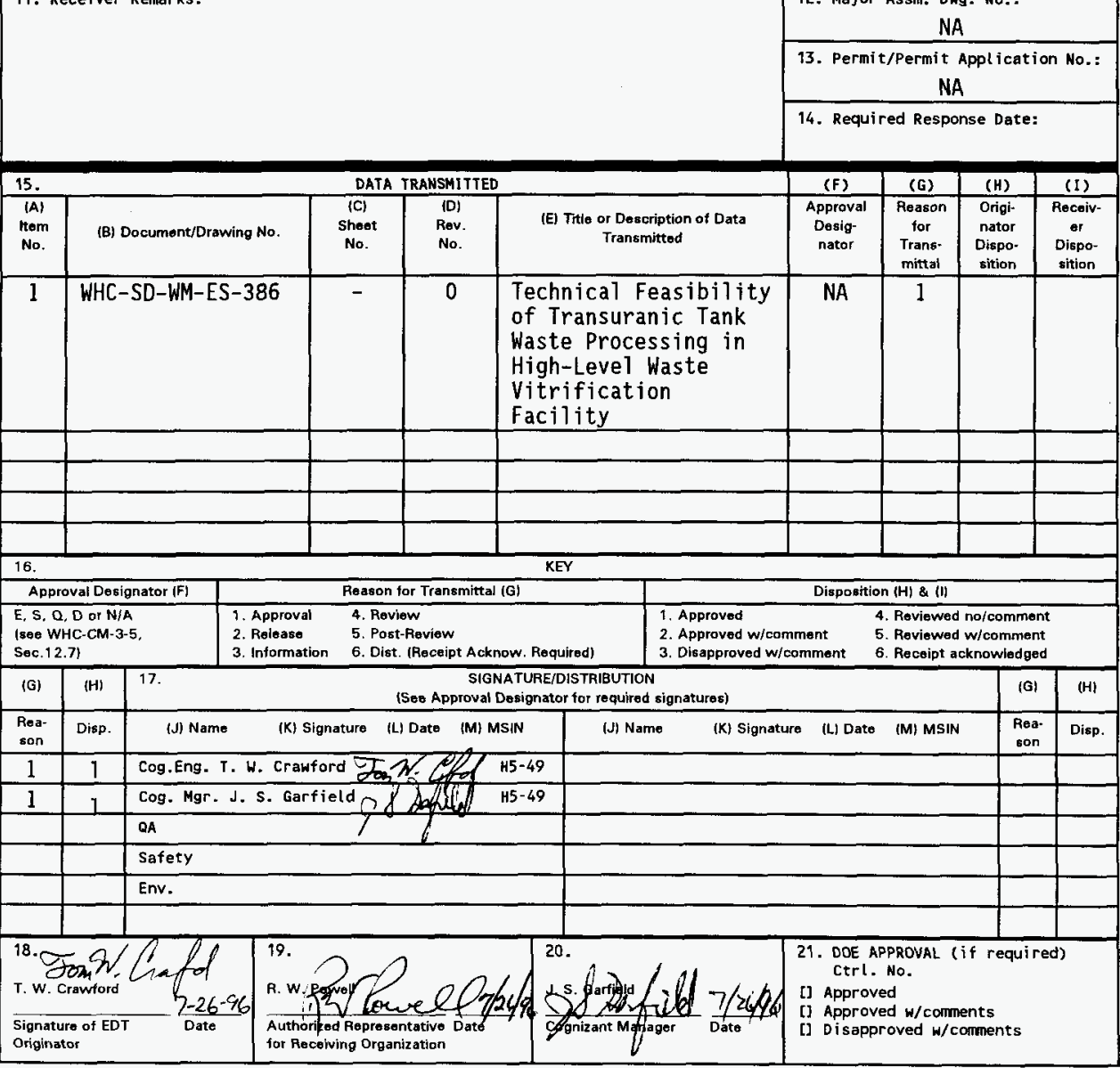




\title{
Technical Feasibility of Transuranic Tank Waste Processing in High-Level Waste Vitrification Facility
}

\author{
T. W. Crawford and A. F. Manuel
}

Westinghouse Hanford Company, Richland, WA 99352

U.S. Department of Energy Contract DE-AC06-87RL10930

EDT/ECN: 608741

UC: 702

Org Code: 73520

Charge Code: D5225

B\&R Code: EW3130010

Total Pages: 110107

Key Words: feasibility, transuranic, high-level waste

Abstract: The objective of this study is to determine the technical feasibility of processing transuranic tank waste in a high-level waste vitrification facility. This is achieved by performing an impact assessment of a reference case high-level waste facility modified to separately process transuranic waste. Data are presented for Hanford Site transuranic wastes and are compared against established waste acceptance criteria for the Waste Isolation Pilot Plant program. Schedule and cost impacts are evaluated for the proposed transuranic campaign.

TRADEMARK DISCLAIMER. Reference herein to any specific commercial product, process, or service by trade name, trademark, manufacturer, or otherwise, does not necessarily constitute or imply its endorsement, recommendation, or favoring by the United States Government or any agency thereof or its contractors or subcontractors.

Printed in the United States of America. To obtain copies of this document, contact: WHC/BCS Document Control Services, P.O. Box 1970, Mailstop H6-08, Richland WA 99352, Phone (509) 372-2420;

Fax (509) 376-4989.

$\frac{\text { Lamid } 1 \text { Sidloge }}{\text { Release Approval }} \frac{-96-96}{\text { Date }}$

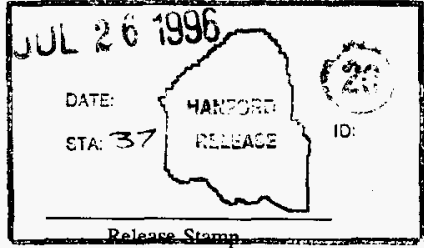

Approved for Public Release 


\section{TECHNICAL FEASIBILITY OF TRANSURANIC TANK WASTE PROCESSING IN A HIGH-LEVEL WASTE VITRIFICATION FACILITY}

July 1996

T. W. Crawford

A. F. Manuel

Westinghouse Hanford Company

Richland, Washington

and

Fluor Daniel, Inc.

Irvine, California

Prepared for:

U.S. Department of Energy

Richland, Washington 
WHC-SD-WM-ES-386

Revision 0

This page intentionally left blank. 


\section{CONTENTS}

1.0 OBJECTIVE $\ldots \ldots \ldots \ldots \ldots \ldots \ldots \ldots \ldots \ldots \ldots \ldots \ldots \ldots \ldots \ldots \ldots$

1.1 BACKGROUND AND SCOPE $\ldots \ldots \ldots \ldots \ldots \ldots \ldots \ldots$

1.2 PURPOSE AND NEED $\ldots \ldots \ldots \ldots \ldots \ldots \ldots \ldots \ldots \ldots$

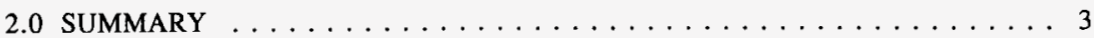

3.0 TECHNICAL FINDINGS AND CONCLUSIONS $\ldots \ldots \ldots \ldots \ldots$

4.0 DESIGN CONCEPTS $\ldots \ldots \ldots \ldots \ldots \ldots \ldots \ldots \ldots \ldots \ldots \ldots$

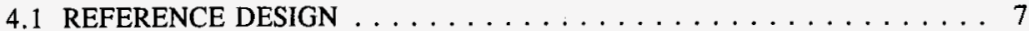

4.1 .1 Packaging Configuration $\ldots \ldots \ldots \ldots \ldots \ldots \ldots \ldots \ldots \ldots \ldots$

4.1 .2 Facility Description . . . . . . . . . . . . . . . 9

4.1.3 Canister, Overpack, and Cask Handling System Descriptions . . . . 11

4.2 TRANSURANIC WASTE VITRIFICATION, REFERENCE CASE

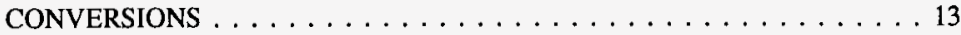

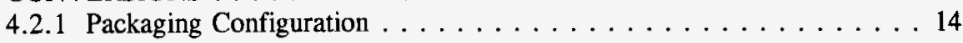

4.2.2 Transuranic Waste Processing . . . . . . . . . . . . 19

4.2.3 Transuranic Waste Form Process Description . . . . . . . . . . . 19

4.3 SUMMARY OF TRANSURANIC CAMPAIGN FACILITY IMPACT $\ldots \ldots 21$

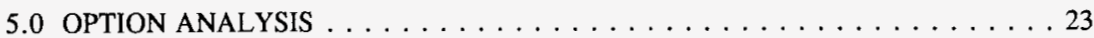

5.1 PROCESS FLOWSHEET/FACILITY DESIGN IMPACT $\ldots \ldots \ldots \ldots 24$

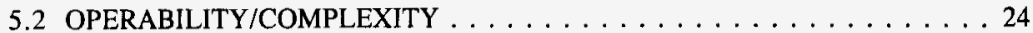

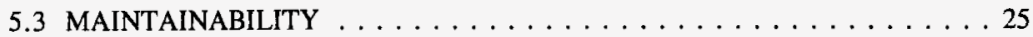

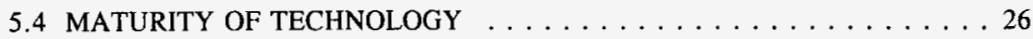

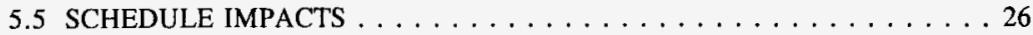

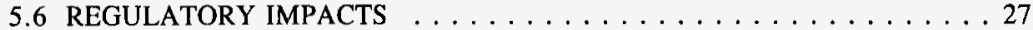

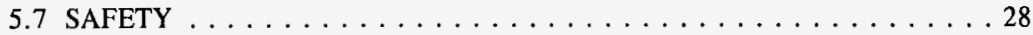

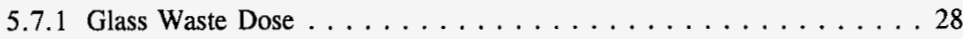

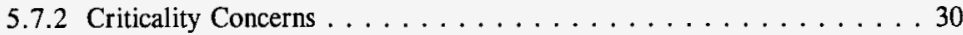

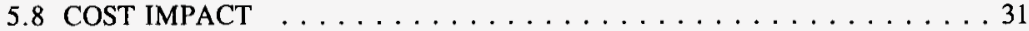

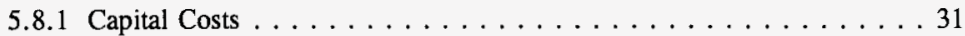

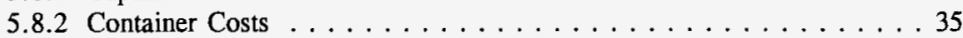

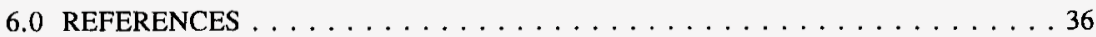


WHC-SD-WM-ES-386

Revision 0

\section{APPENDICES}
A TRANSURANIC WASTE VOLUME PROJECTIONS (REVISION 2) . . . . . A-1
B DRAWING ES-ALT3X-01: HLW 20 MT/D STANDALONE WITH JOULE- HEATED MELTER . . . . . . . . . . . . . . . . B 1
C TRANSURANIC WASTE DISPOSAL AT WASTE ISOLATION PILOT PLANT C-1

\section{LIST OF FIGURES}

4-1. Unshielded Small Canisters (Monolith). . . . . . . . . . . . . . 8

4-2. Concrete Shielded Casks for Unshielded 4-Pack Overpack Canisters (Monolith). . . 10

4-3. Canister, Overpack and Case Handling Systems Block Flow Diagram. . . . . . 12

4-4. Unshielded Transuranic Canisters (Monolith). . . . . . . . . . . . . . 15

4-5. Unshielded Remote Handled Transuranic Canisters Overpack. . . . . . . . . . 17

4-6. Concrete Shielded 4-Pack for Unshielded Remote Handled Transuranic Canister Overpacks (Monolith) . . . . . . . . . . . . . . . . . 18

5-1. Water Content Density Dependency. . . . . . . . . . . . . . . 32

5-2. Sphere Radius Dependency. . . . . . . . . . . . . . . . 33

5-3. Criticality Dependency. . . . . . . . . . . . . . . . 34 


\section{WHC-SD-WM-ES-386 \\ Revision 0 \\ LIST OF TABLES}

4-1. High-Level Waste and Transuranic Waste Estimates (MT of Glass). . . . . . . . 14

5-1. Minimum Transuranic Activity for Contact-Handled/Remote-Handled Transuranic Waste Matrix. . . . . . . . . . . . . . . . . . . . 27

5-2. Maximum Activity for Remote-Handled Transuranic Waste Matrix. . . . . . . 28

5-3. Feed \#1 Shielding Radiation Dose Rates $\left(0.0038 \mathrm{~m}^{3}\right)$. . . . . . . . . . . . 29

5-4. Shielding Dose Rates $\left(1.26-\mathrm{m}^{3}\right.$ Canister $\ldots \ldots \ldots \ldots \ldots$

5-5. High-level Waste and Transuranic Container Costs. . . . . . . . . . 35

\section{LIST OF TERMS}

$\begin{array}{ll}\text { CFR } & \text { Code of Federal Regulations } \\ \text { CH } & \text { Contact handled } \\ \text { CWBS } & \text { Contract Work Breakdown Structure } \\ \text { HLW } & \text { High-level waste } \\ \text { HVAC } & \text { Heating, Ventilation, and Air Conditioning } \\ \text { HWVP } & \text { Hanford Waste Vitrification Plant } \\ \text { OD } & \text { Outer Diameter } \\ \text { RCRA } & \text { Resource Conservation and Recovery Act of } 1976 \\ \text { RH } & \text { Remote handled } \\ \text { SC } & \text { Safety Class } \\ \text { TOE } & \text { Total Operating Efficiency } \\ \text { TRU } & \text { Transuranic } \\ \text { TSD } & \text { Treatment, Storage, and Disposal } \\ \text { TWRS } & \text { Tank Waste Remediation System } \\ \text { WAC } & \text { Washington Administrative Code } \\ \text { WHC } & \text { Westinghouse Hanford Company } \\ \text { WIPP } & \text { Waste Isolation Pilot Plant }\end{array}$


WHC-SD-WM-ES-386

Revision 0

\section{TECHNICAL FEASIBILITY OF \\ TRANSURANIC TANK WASTE \\ PROCESSING IN A HIGH-LEVEL \\ WASTE VITRIFICATION FACILITY}

\subsection{OBJECTIVE}

The objective of this study is to determine the technical feasibility of processing transuranic (TRU) tank waste in a high-level waste (HLW) vitrification facility. This is achieved by performing an impact assessment of a reference case HLW facility modified to separately process TRU waste. Data are presented for Hanford Site TRU wastes and are compared against established waste acceptance criteria for the Waste Isolation Pilot Plant (WIPP) program. Schedule and cost impacts are evaluated for the proposed TRU campaign.

\subsection{BACKGROUND AND SCOPE}

TRU wastes at the Hanford Site account for approximately 8 percent of the estimated volume of HLW proposed for vitrification at the reference case $20 \mathrm{MT} /$ day facility. If this waste volume is campaigned and processed separately from the HLW, packaged TRU waste could ultimately be transported to the WIPP.

A 20-MT/day HLW vitrification facility is considered as the reference case for this study. The reference case has been documented in previous phases of the Tank Waste Remediation System Facility Configuration Study (Boomer et al. 1994) and is discussed in the Alternatives for High-Level Waste Forms, Containers, and Container Processing Systems (Crawford 1995).

To assess the impact of processing a separate TRU waste campaign to the reference case, it is assumed that only those operations down stream of the melter require conversion. This implies that melter feed, melter, and melter offgas operations remain independent of the product campaign conversion. Hence, to evaluate this impact, only modifications to the canister and overpack processing systems must be developed for the remote handled canister configuration acceptable to WIPP. From this information, an assessment relative to the reference case can be made.

Selection criteria are identified as a basis for evaluation. The set of categories include: process flowsheet/facility design impact, operability/complexity, maintainability, maturity of technology, schedule impact, regulatory impact, safety, and capital cost. 
WHC-SD-WM-ES-386

Revision 0

\subsection{PURPOSE AND NEED}

The development and evaluation of alternatives provides a basis for future selection of desired concepts. The intent of this study is to provide data specific to modifying a 20-MT/day HLW facility to campaign both HLW and TRU waste glass forms. The data presented describe and evaluate this modification against the criteria set forth in Section 1.1. The data presented in this report are considered supplemental, and will support future decision processes in the development of a TRU processing strategy and a HLW vitrification facility. 


\subsection{SUMMARY}

It is technically feasible to process transuranic (TRU) tank waste in a high-level waste vitrification facility based on the results of this study. The study evaluates the impact of modifying a reference case HLW facility to process TRU waste. It is assumed that facility modifications are necessary only downstream of the melter system to accommodate a different type of product canister.

Is recommended the TRU waste be campaigned at plant startup to allow for immediate conversion of the HLW campaign following the TRU campaign without requiring system flushing or increasing the waste volume. Two other cases for campaigning TRU waste were evaluated and found to be less desirable.

The radiation dose rate of the product TRU waste glass requires it to be handled as remote handled (RH) TRU waste. The waste would meet all of WIPP's waste acceptance criteria for RH-TRU waste. An estimated volume of between $1,000 \mathrm{~m}^{3}$ and $2,000 \mathrm{~m}^{3}$ of RH TRU glass will be produced, depending on the glass formulation and the amount of blending of the TRU tanks before vitrification. However, it should be noted that an unquantified degree of uncertainty exists as to the availability of the WIPP for Hanford Site vitrified TRU wastes.

The total amount of TRU and HLW glass that would be produced in a modified HLW vitrification facility is between $20,000 \mathrm{MT}$ and $26,000 \mathrm{MT}$, or approximately 3 percent to 13 percent more than the reference case depending on the glass formulation and blending decisions. The impact of this additional glass production on operating costs is not addressed in this study.

An analysis of process flowsheet/facility design impacts, operability/complexity, maintainability, maturity of technology, schedule impacts, regulatory impacts, safety, and cost impact supports the technical feasibility of processing TRU waste in a HLW vitrification facility. 
WHC-SD-WM-ES-386

Revision 0

This page intentionally left blank. 
WHC-SD-WM-ES-386

Revision 0

\subsection{TECHNICAL FINDINGS AND CONCLUSIONS}

Three cases were considered for campaigning TRU waste in a reference case vitrification plant.

- Case 1: Campaign TRU wastes at plant start up

- Case 2: Campaign TRU wastes after a melter change out

- Case 3: Campaign TRU wastes at any plant operating point immediately following HLW.

Both Cases 2 and 3 require dedicated facility features to flush the feed preparation systems and the melter vessel before the conversion from a HLW campaign to a TRU campaign. System flushing will either generate lower waste loadings in the HLW glass, which in effect reduces plant total operating efficiency (TOE) as well as generates more waste volume for ultimate disposal, or will require processing some amount of TRU waste as HLW until the glass chemistry meets WIPP requirements. Case 1 allows for immediate conversion of the HLW campaign following the TRU campaign without requiring system flushing or increasing the waste volume. Additionally, Case 1 allows for the procurement of a reduced capacity melter and a single canister/overpack processing line. This defers procurement of the $20 \mathrm{MT} /$ day melter and the redundant canister/overpack processing system until several years after plant startup. This implies a scheduled melter conversion before campaigning HLW.

Cases 2 and 3 offer no clear advantages in terms of maintainability compared with Case 1. However, if the facility is constructed with no modification as the reference plant (i.e., $20 \mathrm{MT} /$ day melter and 2 canister/overpack process lines), the operability of the second canister/overpack process line after it has set idle for the TRU campaign (approximately 4 years) is questionable.

The single canister/overpack system operations required for the TRU campaign suggest that remote maintenance concepts would be more easily developed and demonstrated at reduced plant capacity. Developed remote maintenance concepts could then be applied to full scale production activities with a high degree of assurance. This maintenance feature is facilitated by Case 1 .

Significant schedule issues for processing TRU and HLW in the same facility include Hanford Federal Facility Agreement and Consent Order (Ecology et al. 1994) (referred to as Tri-Party Agreement) milestones and the WIPP waste emplacement phase schedule. It is demonstrated that all Tri-Party Agreement milestones can be met since the total volume of wastes can be vitrified in 14 years at a significantly reduced plant production rate. However, the WIPP schedule limits the TRU waste acceptance to the year 2018. 


\section{Revision 0}

Appendix $C$ shows the waste emplacement phase of TRU containers at the WIPP is 20 years in duration beginning in fiscal year (FY) 1998 and continuing through FY 2018. During this period, approximately $7,080 \mathrm{~m}^{3}$ of remote-handled (RH) TRU canisters will be accepted by the repository. An estimated volume of between $1,000 \mathrm{~m}^{3}$ and $2,000 \mathrm{~m}^{3}$ of $\mathrm{RH}$ TRU glass will be produced, depending on the glass formulation and the amount of blending of the TRU tanks before vitrification.

It is technically feasible to process transuranic (TRU) tank waste in a high-level waste vitrification facility based on the results of this study. The study evaluates the impact of modifying a reference case HLW facility to process TRU waste. Analysis indicates that facility modifications are necessary only downstream of the melter system to accommodate a different type of product canister. 
Revision 0

\subsection{DESIGN CONCEPTS}

\subsection{REFERENCE DESIGN}

A $20-\mathrm{MT} /$ day HLW vitrification facility producing monolithic waste forms is the reference case for this study. The following sections describe the reference case.

\subsubsection{Packaging Configuration}

The reference case high-level vitrification facility is designed to fill small unshielded metal canisters then seal them in a 4-pack metal overpack. The overpack is placed into a shielded concrete cask for interim storage at the Hanford Site. The paragraphs below offer a process description for the reference case.

Figure 4-1 shows a conceptual sketch of a small unshielded canister filled with HLW monolithic glass. This canister is similar to the Hanford Waste Vitrification Plant (HWVP) canister with slightly modified dimensions. The canister is $4.57 \mathrm{~m}$ tall and $0.68 \mathrm{~m}$ in diameter, and is made of $0.95-\mathrm{cm}$ thick stainless steel on all surfaces. The calculated empty weight of the canister is $785 \mathrm{~kg}$.

The following assumptions are made for the monolithic glass in the canister:

- The canister is filled with glass to approximately $89 \mathrm{~cm}$ from the top of the fill neck of the canister.

- The specific density of the waste glass is $2,643 \mathrm{~kg} / \mathrm{m}^{3}$ irrespective of waste oxide loading.

Based on these assumptions, the total quantity of glass per canister is $1.26 \mathrm{~m}^{3}$ with a weight of $3.33 \mathrm{MT}$. The dose rate on the outer surface of a canister is estimated to be $22.73 \mathrm{~Sv} / \mathrm{h}(2,273 \mathrm{rem} / \mathrm{h})$.

Each of the two canister handling lines in the reference facility are designed to process one canister every 8 hours for a total of four canisters in 16 hours. Once four canisters have been processed and have passed all inspections, they are loaded into a 4-pack overpack. One overpack is therefore produced every 16 hours. 


\section{WHC-SD-WM-ES-386 \\ Revision 0}

Figure 4-1. Unshielded Small Canisters (Monolith).

\section{Stainless Steel \\ Canisters \\ Wall Thickness $0.95 \mathrm{~cm}$}
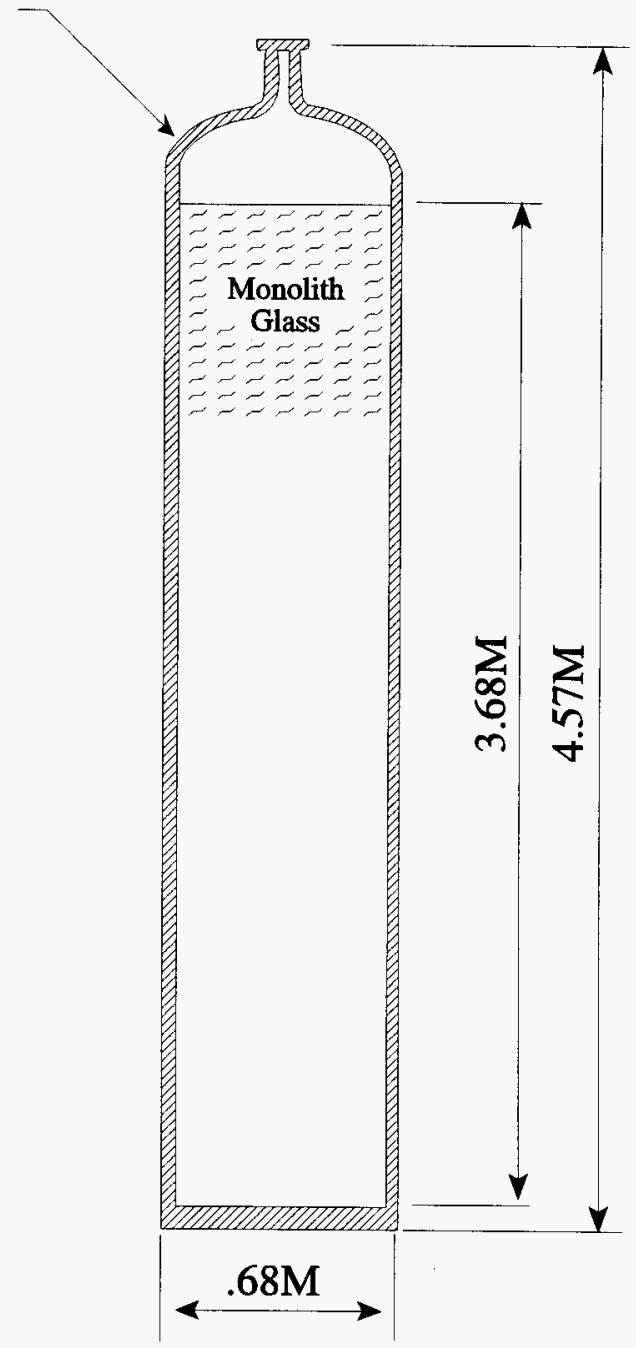
Two glass formulations are being considered for the HLW facility, one using HighLevel Vitrification Plant (HWVP) limits and the other using Composition Variation Study (CVS) limits. These limits are described in Appendix A. Manuel calculated glass volumes and waste oxide loadings based on the TWRS Process Flowsheet, Rev. 1 (Orme 1995) and different glass compositions suitable for different melter types. Details of the calculations are provided in Appendix A. Using the CVS limits will permit a 59 percent waste oxide loading while the HWVP limits will only permit 51 percent waste oxide loading. However, use of the CVS limits has some technical problems, that are beyond the scope of this study, that must be resolved before they can be used. The HWVP limits are the current TWRS baseline (Orme 1995). The total number of canisters produced over the life of the plant will range between 5,940 canisters with CVS limits or 6,860 canisters with HWVP limits.

Figure 4-2 shows a sketch of a concrete storage cask for an unshielded 4-pack overpack that contains four canisters of glass as illustrated in the previous figure. It is assumed that the cask is a cylinder with a flat bottom and flat bolt-on top. The cask's 70 -cm thick wall yields a radiation dose rate of $0.1 \mathrm{mSv} / \mathrm{h}$ at the outer surface of the cask. The calculated empty weight of the cask is $90 \mathrm{MT}$. The weight of a cask that contains an overpack loaded with four canisters filled with monolithic glass is $112.96 \mathrm{MT}$. Based on the canister processing rate discussed above, a full cask is produced every 16 hours. The total number of overpacks produced over the life of the plant will vary between 1,485 and 1,715 depending on the glass formulation.

\subsubsection{Facility Description}

A plan and two elevations views of the reference HLW vitrification facility are contained in Appendix B. The vitrification building features a modular design reflecting an anticipated need for process flexibility and periodic large component replacement.

The melter cell depicted is configured for a joule-heated melter. Molten glass is gravity poured through an opening in the melter cell floor into a $4.57-\mathrm{m}$ tall stainless steel canister. The canister is located at a fill station underneath the melter cell. The melter cell also contains the close-coupled quench tower, venturi scrubber, and chiller of the melter offgas system. The remaining remote portions of the melter offgas system are contained in the metal filter area in the chemical process cell.

The canister processing area contains two basement level compartments for filling, welding, decontaminating, and smear testing for both canisters and overpacks. There are two independent canister processing cells and a single canister overpack cell. The canister handling cells are located adjacent to the melter cell at the side of the building. 


\section{WHC-SD-WM-ES-386}

\section{Revision 0}

Figure 4-2. Concrete Shielded Casks for Unshielded 4-Pack Overpack Canisters (Monolith).

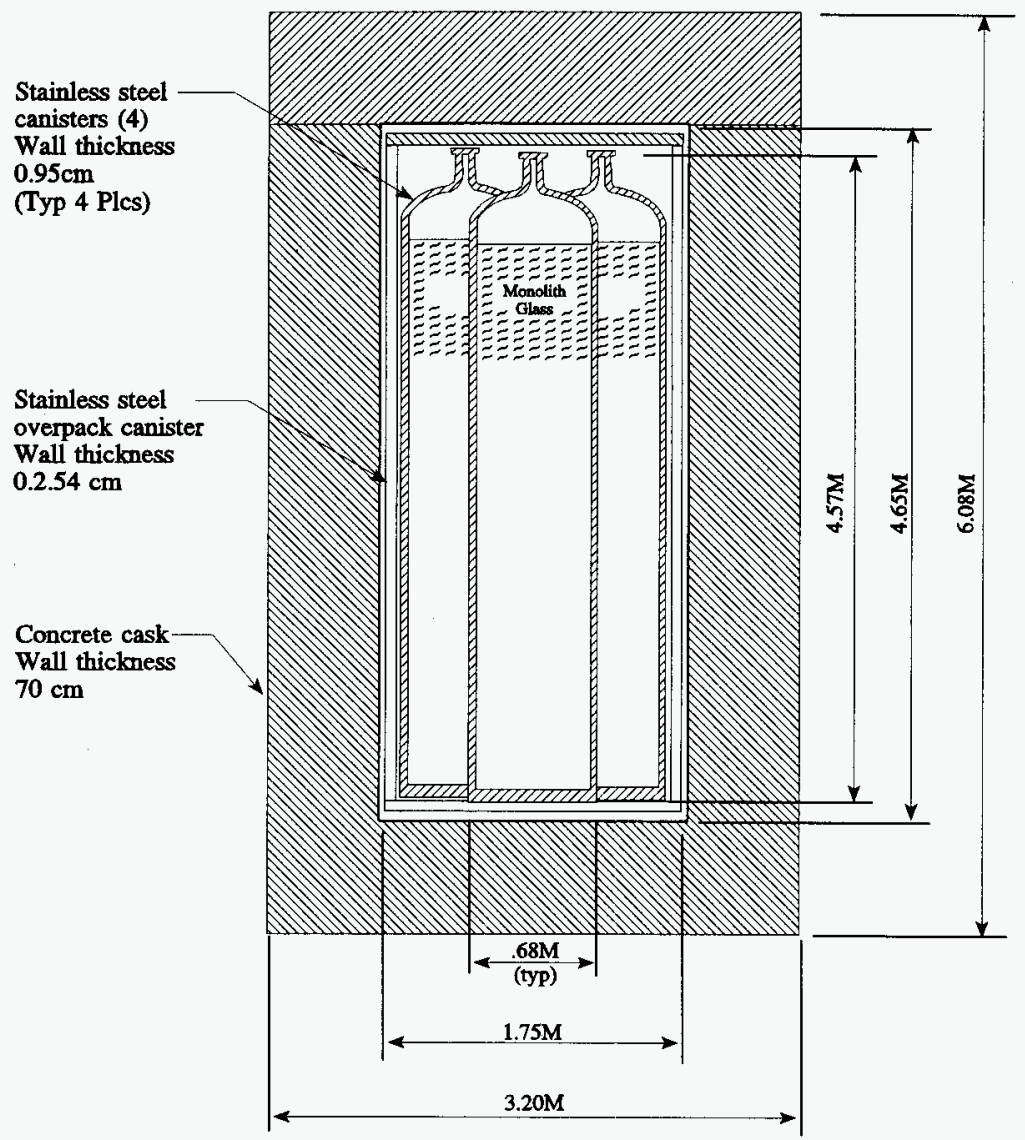


WHC-SD-WM-ES-386

Revision 0

\subsubsection{Canister, Overpack, and Cask Handling System Descriptions}

Figure 4-3 depicts a block flow diagram of the canister, overpack, and cask handling operations. Rail cars or trucks transport the canisters and overpacks to the vitrification plant site. A modified fork lift unloads empty canisters from rail cars and transports them to the Canister/Cask Handling Annex. A modified fork lift or gantry crane unloads empty overpacks and moves them into separate staging areas within the Annex. Overhead cranes are used to manage the canister, overpack, and cask inventory in the annex.

The Canister/Cask Handling Annex is an annex to the HLW vitrification facility. The canisters, overpacks, and casks move from receiving areas into the Canister/Cask Handling Annex for unpacking, inspection, lag storage, and movement to the appropriate load-in station. The annex ensures quality control over the canister/cask and reduces the exposure to the external environment by maintaining a shielded lag storage area for filled concrete casks awaiting transfer from the facility. Canister/ overpack load-in stations and the overpack load-out station are integral to the Annex. Overhead cranes are used to move canisters, overpacks, and casks in the facility.

Empty canisters are introduced into the load-in station in the vitrification building from the Canister/Cask Handling Annex. The canister processing cell contains two parallel cart track systems for processing canisters through the stations. The carts ride on rails for load-in, fill, and unloading at the cooling rack, and are provided with a support basket used to lift the heated canisters after fill operations. Empty baskets are placed back into carts which then back up to the canister load-in station where they are staged to receive the next empty canister. Once a canister is loaded onto a cart, the cart transfers the canister to the fill station beneath the melter. The cart transports the filled canisters into the canister cooling cell where a weld plug is inserted. A canister handling robot lifts the basket (canister inside of it) out of the cart and places it into one of the available cooling positions in the 36-position cooling rack. Canisters are cooled in separate, insulated racks. The robot's operation is completely automated. Sixteen of the rack's 36 positions are for cooling and 20 positions are for lag storage. After each canister is cooled for approximately 50 hours, the canister handling robot moves the canister through a hatch and onto an empty cart on the next transfer system.

The cart transports cooled canisters to the weld and inspection stations. After welding and inspection, the canister is moved into the decontamination station. Decontamination operations are performed by another canister handling robot. The canister handling robot places the canister into a decontamination tank. Once the canister has completed decontamination operations, the canister handling robot moves the canister into the rinse and dry tank. The empty cart backs up to the load/unload position where it is staged to receive the next cooled canister. 


\section{WHC-SD-WM-ES-386 \\ Revision 0}

Figure 4-3. Canister, Overpack and Case Handling Systems Block Flow Diagram.
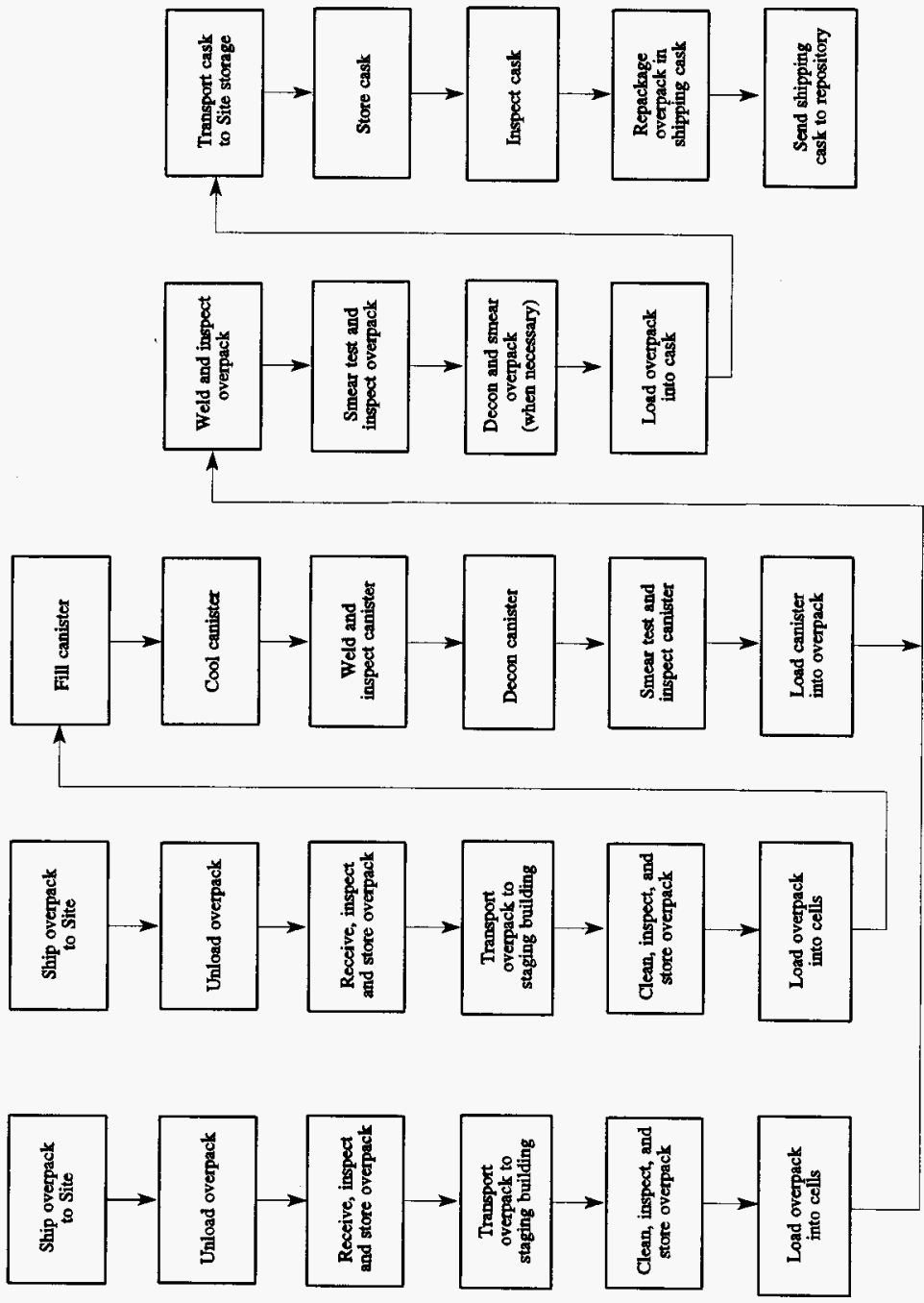
From the rinse tank, the canister is lifted through a hatch by another canister handling robot and, if required, smear tested. However, normal operations are not expected to require smear testing, so canisters are lowered through another hatch directly into a metal overpack in the overpack station. Each overpack is loaded with four canisters. The overpacks are brought into the overpack area on carts. The cart system is considered to be a "clean system" and is contact maintained. After the fourth canister is placed into an overpack and the lid is placed, the cart transports the overpack to a weld and inspection area. After a successful weld and inspection is performed, the cart moves the overpack into a smear test area. An overpack handling robot then picks up the overpack from the cart and places it on the smear test turntable. The empty cart then returns to receive another overpack.

Upon completing a successful smear test, the handling robot transports the overpack into the load-out area. If the overpack fails smear testing, it is lowered through a hatch into the overpack decontamination cell. After decontamination, the overpack is transferred back to the smear test station for another smear test. The overpack leaves the smear test area via the handling robot. The robot places the metal overpack on a stand that is located beneath the overpack load-out hatch. An overhead bridge crane, located in the cask loading room, lifts the metal overpack off of the stand and into the cask loading room; a shielded area integral to the Canister/Cask Handling Annex. Inside the cask loading room, the crane places the metal overpack into a concrete cask, places a concrete lid onto the cask, then bolts down the lid before cask removal. The cask is moved by a cask transporter into the staging area. An empty cask is brought into the cask loading room by the cask transporter for continued operations. Filled casks are staged in the Canister/Cask Handling Annex until such time that they are transferred to a storage location. The staging area of the Annex requires only light shielding since the casks are designed to reduce dose rates from the "worst case" canisters to $10 \mathrm{mrem} / \mathrm{h}$. This annex is contact maintained.

\subsection{TRANSURANIC WASTE VITRIFICATION, REFERENCE CASE CONVERSIONS}

This section identifies those systems of the reference HLW vitrification facility that would be affected by a conversion to TRU waste vitrification campaign. The reference case HLW vitrification facility assumed a total of between 20,000 MT and 23,000 MT of glass was required to be produced over the lifetime of the plant, again depending on the glass formulation selected. For the conversion case, the total volume of glass to be produced over the lifetime of the plant changes due to waste blending, addition of glass formers, etc. The estimated amount of HLW glass to be produced in the conversion plant is between 18,000 and 20,000 MT, and the amount of TRU glass to be produced is between 2,600 MT and 5,300 MT depending on the glass formulation selected and whether TRU wastes are blended before vitrification or not. Hence, the total amount of glass required to be produced in the conversion plant is between $20,000 \mathrm{MT}$ and $26,000 \mathrm{MT}$, approximately 3 percent to 13 percent more than the reference case depending on the glass formulation and blending decisions. Table 4-1 illustrates this data. 
WHC-SD-WM-ES-386

Revision 0

Table 4-1. High-Level Waste and Transuranic Waste Estimates (MT of Glass).

\begin{tabular}{|c|c|c|c|c|c|}
\hline \multirow{2}{*}{$\begin{array}{l}\text { Glass } \\
\text { Formulation }\end{array}$} & \multirow{2}{*}{$\begin{array}{l}\text { High level } \\
\text { waste } \\
\text { processing only }\end{array}$} & \multirow{2}{*}{$\begin{array}{c}\text { Blending of } \\
\text { transuranic } \\
\text { waste }^{\mathrm{a}}\end{array}$} & \multicolumn{3}{|c|}{ Transuranic processing } \\
\hline & & & $\begin{array}{l}\text { High-level } \\
\text { waste }\end{array}$ & Transuranic & Total \\
\hline HWVP & 22,845 & \multirow{2}{*}{ No } & 20,481 & 5,252 & 25,753 \\
\hline CVS & 19,781 & & 17,683 & 4,456 & 22,139 \\
\hline HWVP & N/A & \multirow{2}{*}{ Yes } & 20,481 & 3,427 & 23,908 \\
\hline CVS & N/A & & 17,683 & 2,634 & 20,317 \\
\hline
\end{tabular}

'Without blending, the transuranic waste oxide loading is more severely limited by the solubility of $\mathrm{ZrO}_{2}, \mathrm{Cr}_{2} \mathrm{O}_{3}$, and/or $\mathrm{P}_{2} \mathrm{O}_{5}$.

${ }^{b} \mathrm{CVS}$ limits allow greater waste oxide loading than HWVP limits.

It is assumed that only the operations down stream of the melter require conversion for TRU waste processing. This implies the feed preparation and melter systems are not impacted by the conversion. This assumption clearly attempts to minimize facility and operational impacts of the reference case during the conversion of waste product campaigns. This is referred to as the minimal impact scenario. Other melter types such as those with a steep sloped wall and bottom pour required for producing a crystalline waste product, are not specifically addressed in this report.

\subsubsection{Packaging Configuration, Modifications}

The quantity of HLW glass produced in the conversion plant will decrease by approximately 10 percent due to the separate TRU campaign. This implies that the number of HLW packages discussed in Section 4.1.1 required to package all HLW will decrease. The previous section identified between 18,000 MT and 20,000 MT of HLW to be vitrified in the conversion plant. This figure implies that between 5,310 and 6,150 canisters and between 1,330 and 1,540 overpacks and concrete casks will be produced during the HLW campaign.

Figure 4-4 illustrates a modified HLW canister that may be used during the production of TRU monoliths. The TRU canister will be $2.91-\mathrm{m}$ tall and $0.64 \mathrm{~m}$ in diameter. The canister is made of stainless steel and is assumed to be $0.95-\mathrm{cm}$ thick on all surfaces. The calculated empty weight of the canister 0.4 MT. The pintle design of the TRU canister is identical to the HLW canister design. This design feature allows the melter fill system (pour spout interface to the canister) and canister handling robots to remain independent of the canister/campaign conversion and will not affect plant TOE during the change in waste campaigns. 
WHC-SD-WM-ES-386

Revision 0

Figure 4-4. Unshielded Transuranic Canisters (Monolith).

Stainless Steel

Canisters

Wall Thickness

$0.95 \mathrm{~cm}$ (3/8 in.)

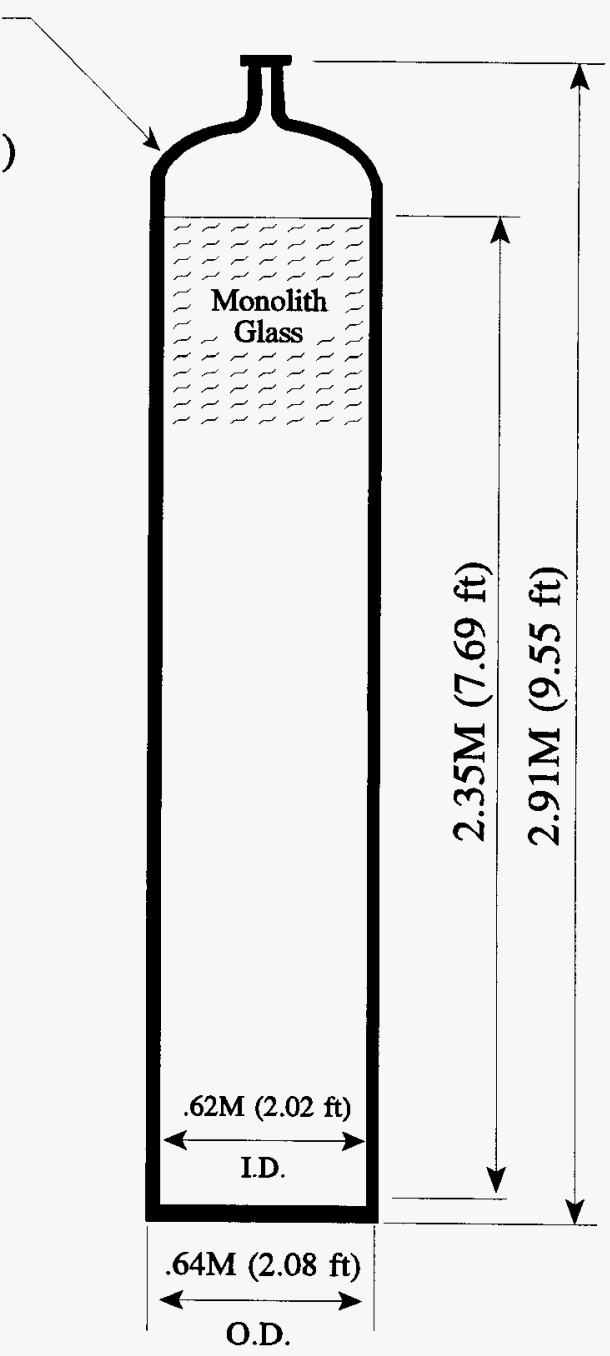


WHC-SD-WM-ES-386

Revision 0

The following assumptions are made for the monolithic glass in the canister:

- The canister is filled with glass to approximately $55 \mathrm{~cm}$ from the top of the canister.

- The specific density of the waste glass is $2,643 \mathrm{~kg} / \mathrm{m}^{3}$ irrespective of waste oxide loading.

Based on these assumptions, the total quantity of glass per TRU canister is $0.71 \mathrm{~m}^{3}$ with a weight of $1.88 \mathrm{MT}$, or approximately 58 percent of that held in a HLW canister. For a total TRU production of between 2,634 MT and 5,252 MT, the number of TRU canisters will be between 1,401 and 2,794.

Figure 4-5 illustrates a sketch of the RH TRU canister that will be used as an overpack for the TRU canister shown in Figure 4-4. The RH TRU canister overpack will be constructed to meet structural requirements and design conditions for Type A packaging specified in 49 CFR 173.412. Additionally, the RH TRU canister overpack will be certified to the WIPP-approved specifications. The overpack is $3.07 \mathrm{~m}$ in length, $0.66 \mathrm{~m}$ in outside diameter with a wall thickness of $0.64 \mathrm{~cm}$, and is constructed out of ASTM A516 Grade 55 , a carbon steel with improved notch toughness. The RH TRU canister overpack is assumed to be a cylinder with a flat bottom and reverse flanged head. The head configuration, consisting of the flange and axial lifting pintle, is welded onto the overpack cylinder after it is overpacked with the TRU canister.

Current WIPP acceptance criteria requires the pintle assembly to be fitted with a carbon composite high-efficiency air (HEPA) filter system with a minimum airflow of $3,000 \mathrm{cc} / \mathrm{min}$. This requirement exists since current WIPP qualified waste forms may generate gases inside the canister. Since none of the qualified waste forms considered are vitrified glass, the HEPA filter would not be expected as a requirement for RH TRU canisters as vitrified waste forms are proposed to the WIPP. The RH TRU canister overpack assumed for this study does not include a canister filter system.

The calculated empty weight of the overpack is $0.39 \mathrm{MT}$. The weight of an overpack containing a canister filled with monolithic glass is $2.66 \mathrm{MT}$. This weight is below the limit of the WIPP acceptance criteria for remote handled canisters of 3.34 MT.

Figure 4-6 shows a conceptual sketch of a TRU shielded concrete storage cask. This cask will contain 4 unshielded RH TRU canisters in interim storage until such time that they are prepared for transfer to the WIPP. It is assumed that the cask is a cylinder with a flat bottom and flat bolt-on top. The cask's $49-\mathrm{cm}$ thick wall yields a radiation dose rate of $0.1 \mathrm{mSv} / \mathrm{h}$ at the outer surface of the cask. The calculated empty weight of the cask is 35.98 MT. The weight of a cask that contains four RH TRU canisters overpacked with monolithic glass is $46.62 \mathrm{MT}$. 
WHC-SD-WM-ES-386

Revision 0

Figure 4-5. Unshielded Remote Handled Transuranic Canisters Overpack.

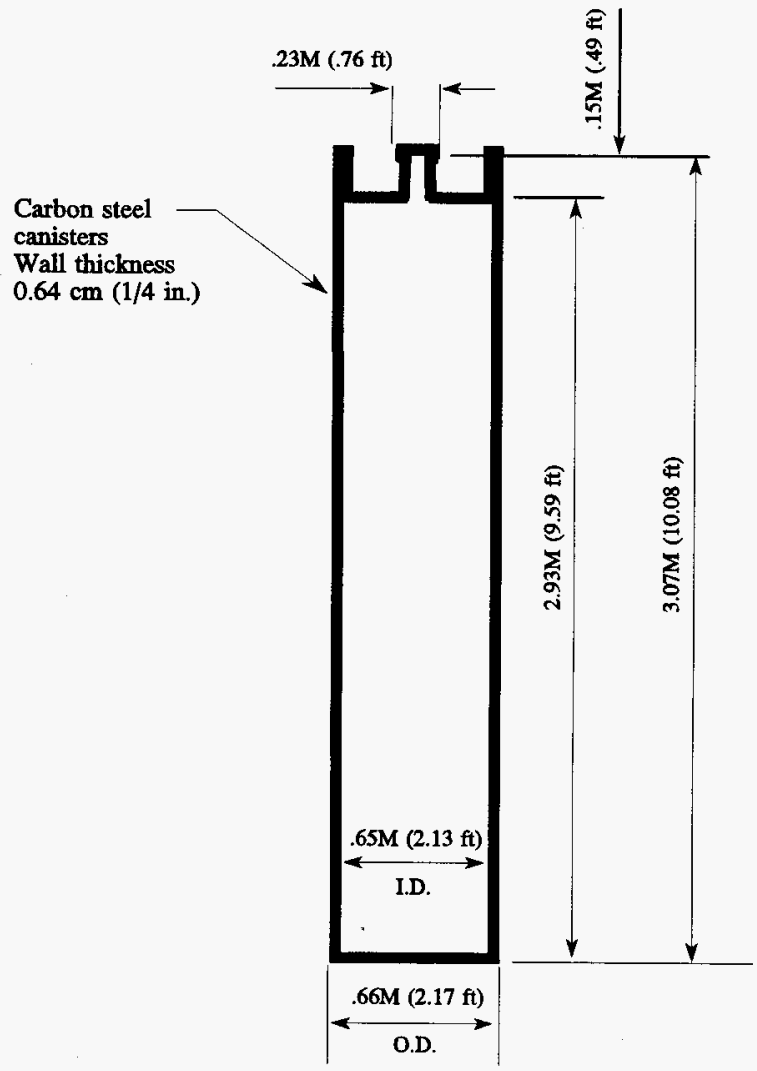




\section{WHC-SD-WM-ES-386}

\section{Revision 0}

Figure 4-6. Concrete Shielded 4-Pack for Unshielded Remote Handled Transuranic Canister Overpacks (Monolith).

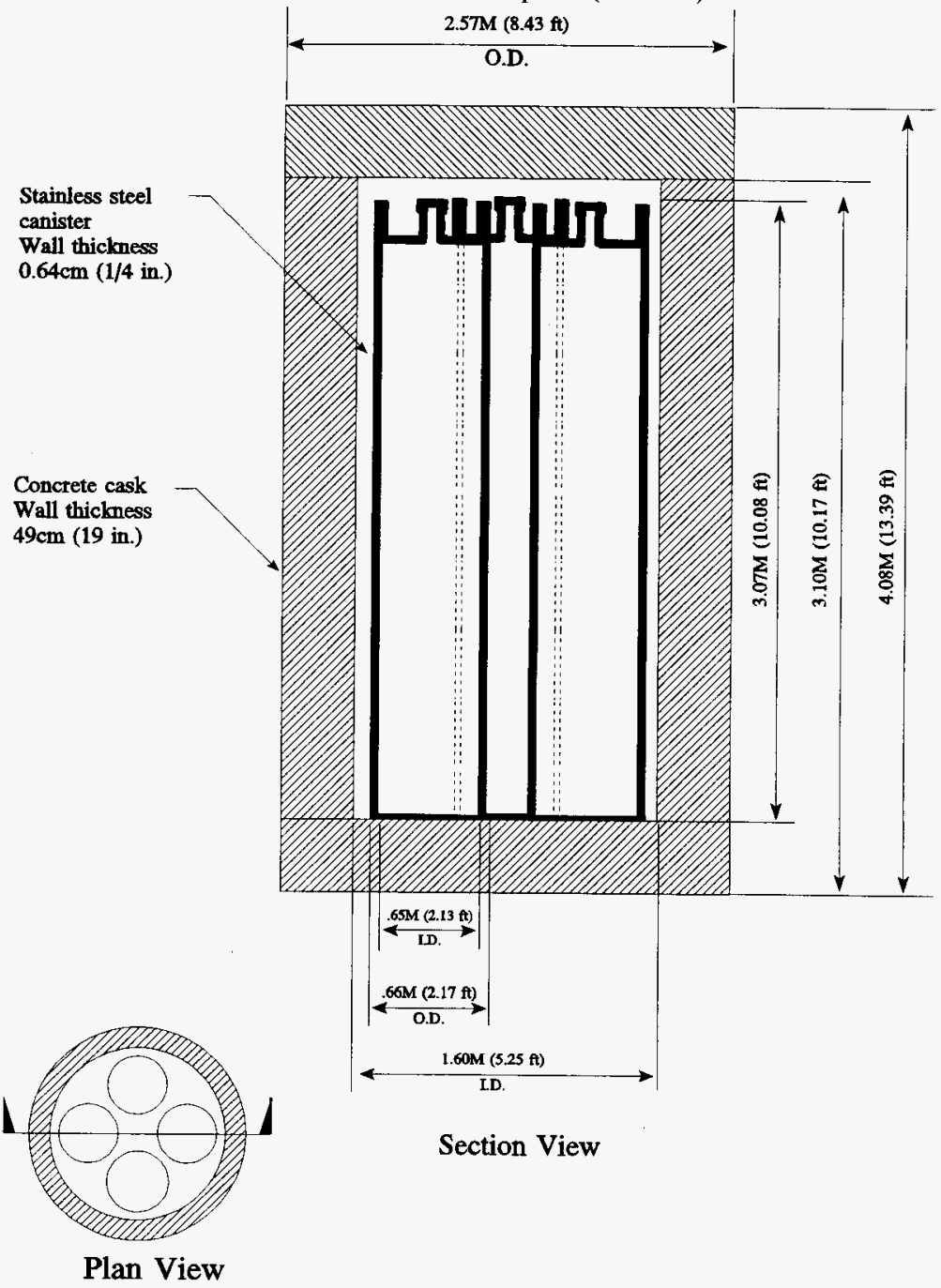


WHC-SD-WM-ES-386

Revision 0

\subsubsection{Transuranic Waste Processing}

Conversion from a HLW campaign to a TRU waste campaign will require minimal modifications to the reference facility. As discussed in Section 4.2, the minimal facility impact scenario requires that any TRU waste campaign impose limited modifications to the existing reference facility.

For reference overpack contains four canisters. This $4: 1$ canister to overpack ratio allows up to 16 hours to process an overpack in order to meet plant design capacity of 20-MT/day (the rate at which canisters are produced is two every 8 hours). Since the TRU overpack configuration assumes a 1:1 canister to overpack ratio, and considering that 2 canister processing lines converge to a single overpack line, an overpack would have to be processed in the one half the time it takes a canister to be processed (i.e., 4 hours) in order to maintain the plant design capacity during the TRU campaign. This is not considered likely, so the minimal impact scenario does not assume plant design capacity is maintained during the TRU waste campaign.

Conservatively, it is assumed that a TRU canister could be processed at an equivalent rate as the larger HLW canisters; one every 8 hours on each canister processing line. Furthermore, it is assumed that an overpack could be processed in the same amount of time that it takes to process a canister, or 8 hours. Given the 1:1 canister to overpack process timing ratio, only one of the canister process lines are required to operate for the minimal impact scenario during the TRU campaign.

For this campaign, the plant output of vitrified TRU product is $5.6 \mathrm{MT} /$ day, or approximately 28 percent the reference plant's design capacity. This is a result of the single canister and overpack lines, as well as the reduced glass volume of the TRU canister (approximately 56 percent of the volume). The total number of TRU canisters and overpacks produced over the life of the facility is between 1,401 and 2,794 . Since four overpacks will be loaded into each cask, between 350 and 699 overpacks will be produced.

\subsubsection{Transuranic Waste Form Process Description}

The minimal impact scenario requires limited facility modifications to produce monolithic TRU waste forms and package them. As discussed in the previous section, a reduced capacity plant would involve a single canister processing line and the overpack line, and assume similar time requirements for canister processing. As a result, facility modifications for the TRU campaign affect these systems minimally.

Figure 4-3 depicts a block flow diagram of the canister and overpack handling systems for the reference case. During a TRU campaign, the TRU canister and overpacks will be processed similarly using the same transfer systems and canister/overpack operations. The following paragraphs discuss the primary modifications required to the reference systems during a conversion in waste form campaigns. 
Only a single track in the canister processing cell will be required for processing TRU canisters through the stations. The carts, not requiring modification, ride on the same rail system for load-in, fill, and unloading at the cooling rack. However, the support baskets used to lift the heated canisters after filling, require modification to ensure that melter fill operations are not affected by the TRU canister change over (recall that it is shorter than the reference canister). The primary modification to the basket requires that the pintle of the TRU canister be at the same elevation as the reference case canister. This is easily accomplished by adjusting the base of the basket. Hence, load-in, fill and unloading operations, as well as all basket transfer operations by the canister handling robot are performed similarly, independent of the TRU canister.

Once cooled, the canister handling robot uses a pintle grapple and lifts the TRU canister from the cooling rack and places it on the cart system traveling to the weld and inspection stations. Minor modifications to the transfer carts (or replacement) are required to maintain the same elevation of the TRU canister as the reference case. Welding and inspection for the TRU canister are essentially the same as for the reference case since the canister material and geometry (around the weld area) are the same.

After welding and inspection, the TRU canister is moved into the decontamination station. Decontamination operations are performed by the bridge mounted canister handling robot used in the reference case. The canister handling robot lifts the TRU canister into a decontamination tank. Minor adjustments to the decontamination tank (e.g., canister rack), or reprogramming the canister handling robot are required for the placing the different sized TRU canister into the decontamination tank. Once the canister has completed decontamination operations, the canister handling robot moves the TRU canister into the rinse/dry tank. The empty cart backs up to the load/unload position where it is staged to receive the next cooled TRU canister.

From the rinse/dry tank, the TRU canister is lifted through a hatch by the canister handling robot and, if required, smear tested. However, normal operations do not require smear testing, so TRU canisters are lowered through another hatch directly into a RH TRU canister overpack in the overpack station. The RH TRU canister overpack is brought into the overpack area on a specially modified railed cart (modified from the reference case). The cart system is still considered to be a "clean system" during the TRU campaign.

After the TRU canister is placed into an overpack, a cart transports the overpack to the weld and inspection area. Since the weld parameters have changed considerably with the change in overpack, the weld head assembly must be replaced before the TRU campaign. This activity is easily accomplished since the overpack area is considered a "clean system" and can be routinely scheduled. After a successful weld and inspection is performed, the cart moves the RH TRU canister overpack into a smear test area. The overpack handling robot picks up the overpack and places it on the smear test turntable. This robot's grappling mechanism will have to be modified to interface with the TRU overpacks. The empty cart then returns to receive another overpack. Although the smear test station is designed for the reference case overpack, it is assumed to be reprogrammable to survey the RH TRU canister 
overpack. WIPP surface contamination limits for RH TRU canisters are $50 \mathrm{pCi} / 100 \mathrm{~cm}^{2}$ alpha, and $450 \mathrm{pCi} / 100 \mathrm{~cm}^{2}$ beta-gamma.

Upon completing a smear test, the handling robot transfers the RH TRU canister overpack into a decontamination area. The overpack is decontaminated only if the smear test shows unacceptable contamination levels. If an overpack requires decontamination, it is moved back to the smear test station for a final smear test after the decontamination process is completed. The RH TRU canister overpack leaves the decontamination area via the handling robot. The robot places the overpack on a stand that is located beneath the cask loading room hatch. The lifting device on the bridge crane located in the cask loading room has been changed to lift the RH TRU canister overpack by the axial lifting pintle. Four RH TRU canister overpacks are loaded into a TRU shielded concrete cask in the Canister/Cask Handling Annex as discussed in Section 4.1.3 above. The casks are identified as containing TRU materials, and are staged until such time that they either go to interim site storage or are processed for transfer to the WIPP repository.

\subsection{SUMMARY OF TRANSURANIC CAMPAIGN FACILITY IMPACT}

The minimal impact scenario imposes only minor changes to the reference design as described below. A single canister processing line and the overpack line are required to process vitrified TRU waste form packages at approximately 28 percent of plant design capacity, or roughly at $5.6 \mathrm{MT} /$ day. All transfer systems and canister/overpack functions remain unchanged during the TRU campaign conversion. Physical changes will be required for the lifting baskets, canister and overpack transfer carts, overpack handling robot interface devices, weld head for the RH TRU canister overpack, and programming logic changes for the several functions (e.g., decontamination, smear testing, overpacking, etc.). The following points are noted for the minimal impact scenario:

- TRU wastes can be processed in the reference facility without interrupting melter operations.

- If HLW operations begin before TRU processing, the melter feed system and the melter vessel will have to be flushed.

- TRU wastes can be processed in the reference facility without materially increasing the total amount of glass produced.

- The canister interface with the fill system (pour spout) remains unchanged during the campaign conversion.

- The canister processing/handling systems require only modification before the TRU waste campaign. 
WHC-SD-WM-ES-386

Revision 0

This page intentionally left blank. 


\subsection{OPTION ANALYSIS}

The following sections evaluate a conversion of a reference HLW plant to campaign TRU wastes with minimal impact to the reference design. The assessment categories are introduced in Section 1.1 and include: process flowsheet/facility design impact, operability/complexity, maintainability, maturity of technology, schedule impact, regulatory impact, safety and cost. Although this study assumes minimal impact to the reference facility, three cases are considered for which a TRU campaign can be run:

- Case 1: Campaign TRU wastes at plant start up.

- Case 2: Campaign TRU wastes after melter change out.

- Case 3: Campaign TRU wastes at any plant operating point immediately following HLW.

Two other sets of alternatives are also evaluated. The melter can be either high temperature or low temperature. High temperature melters allow a higher waste oxide loading and therefore less total glass production for both HLW and TRU. TRU processing has little input to the high versus low temperature decision, but that decision has financial impacts on the TRU processing evaluation.

In the second alternative, the TRU waste located in the underground tanks can be either blended together before processing or processed tank by tank. If processing is performed tank by tank, solubility limits are reached by certain chemical species before the maximum waste oxide loading is reached. Each tank contains different chemical species, so that blending all of the tanks before vitrification dilutes the concentration of each of them, thus allowing the maximum waste oxide limit to be reached. Blending, therefore, has the effect of reducing the total amount of TRU glass that must be produced.

The economics of the two bounding alternatives are evaluated to look at the sensitivity of these decisions on the outcome of this study:

- Alternative 1: High temperature melter and full blending to obtain the least amount of glass.

- Alternative 2: Low temperature melter and no blending to obtain the maximum amount of glass.

The following evaluation will consider impact of each case to the reference facility. Both processing alternatives will be considered in the cost analysis section. 
WHC-SD-WM-ES-386

Revision 0

\subsection{PROCESS FLOWSHEET/FACILITY DESIGN IMPACT}

Both cases 2 and 3 require that the feed system and melter vessel be flushed of HLW before TRU processing begins. These cases require dedicated facilities/systems to flush, catch, test and recycle feed product, or to flush, test, and vitrify feed product before processing TRU wastes. The alternative to flushing and catching feed product during the TRU conversion is to process nonradioactive feed and produce extra low concentrate HLW monoliths during the system flush. This method of flushing is assumed to have a smaller impact on the design of the facility.

\subsection{OPERABILITY/COMPLEXITY}

Case 1 does not require a flush system on the feed preparation system. Since flushing is not required, this option minimizes the operational impact of the TRU conversion. Immediately following the TRU campaign, HLW can be introduced into the feed systems without an interruption in plant schedule. This case represents the optimal case (given the assumptions of this study) between maximizing plant TOE and minimizing glass volumes (reduces flush volume).

The primary operational issue for all cases is the operation of the melter during the TRU campaign. For the minimal impact scenario, the reference plant is modified to vitrify and package TRU waste. Since the converted plant is limited by its overpacking capability, output during TRU processing is approximately 25 percent of the rated design capacity. This requires the reference case $20-\mathrm{MT} /$ day melter to be operated at approximately 5-MT/day for the TRU campaign. Several alternatives exist for this operation:

- The 20-MT/day melter is designed to operate at a reduced capacity for the TRU campaign.

- The 20-MT/day melter is operated in batch mode. That is, the melter fills TRU canisters until all lag storage positions in the canister cooling rack are occupied. The melter is idled until all TRU canisters are processed by the canister/overpack lines.

- A 5-MT/day melter is procured specifically for the minimal impact scenario and is changed-out after the TRU campaign.

Although these options are not discussed in detail, the last alternative has some cost advantages and is discussed briefly in Section 5.8 .

Case 2 requires flushing the feed preparation system before processing TRU wastes after a melter change out. In this case, the glass volume inside the "old" melter may or may not be included in the flushing since it may be a scheduled or unscheduled melter change-out event. In the event where it is a scheduled change-out, the feed preparation system and 


\section{WHC-SD-WM-ES-386 \\ Revision 0}

melter will be flushed, processed, and vitrified; the flush product will be categorized as HLW glass (with diluted oxide loading).

In the event where melter change-out is unscheduled, the feed preparation system could be flushed, processed, and maintained. Vitrification of the flush product would occur after the melter has been replaced. After the flush product and entire volume of TRU waste has been vitrified, the plant may resume a HLW campaign. (No flushing is required for this campaign conversion.) The volume of glass inside the "old" melter would be recovered by systems in the melter cut up cell for later recycle.

Case 3 campaigns TRU wastes at any time during the lifetime of the reference plant and includes the melter as integral to the system requiring flushing. This campaign conversion would be considered a scheduled event, where flushing, processing and vitrification of the flush product would be similar to Case 2 above with the melter on-line. A desirable alternative to this option would be to campaign TRU wastes following vitrification of all HLW volumes. Before processing TRU waste forms in the canister/overpack process areas, the melter may be required to idle while minimal hardware modifications and independent verifications are made to the canister/overpack processing lines. This method affects plant TOE and increases disposal costs by increasing the volume of vitrified HLW. During the TRU campaign, the second (and unused) canister processing line could be used as a back-up system, or for spare parts. The second canister processing line would not require restart after the TRU campaign.

\subsection{MAINTAINABILITY}

In general, all cases that campaign TRU wastes before HLW imply that one of the two canister processing lines sit idle during the TRU campaign. This suggests that the idle canister processing line is expected to restart after the TRU campaign so the reference facility can assume its rated production capacity. In all such cases, this operating scenario presents a high degree of uncertainty as to the availability considerations for the idle canister processing line during start-up and normal operations. On the other hand, this scenario does imply that the availability of the TRU canister process line, given a backup system is on stand-by, is very high (with the exception of shared material handling devices).

Case 1 requires processing TRU wastes at the beginning of plant life. This offers some advantages over other alternatives. For instance, the minimal impact scenario requires only a single canister processing line for the TRU campaign at approximately 25 percent plant design capacity. Assuming the other processing line remains unused, any decontamination activities for scheduled or unscheduled contact maintenance activities is facilitated. Additionally, the reduced capacity of the TRU campaign is ideal for the development and demonstration of remote and semi-remote maintenance concepts (smaller source terms and less contamination) to be used during full-scale production activities. 


\subsection{MATURITY OF TECHNOLOGY}

Maturity of technology is not considered an issue since both campaigns use similar technologies.

\subsection{SCHEDULE IMPACTS}

Processing TRU waste in the HLW vitrification plant will increase the completion date of HLW processing by 2.3 years if HWVP limits are used, and by only 1.6 years if CVS limits are used. A melter using HWVP limits is expected to allow a 52 percent HLW waste oxide loading and a melter using CVS limits is expected to allow a 60 percent HLW waste oxide loading.

A letter from Mark W. Frei, Office of Waste Management Projects, to Mr. Jack Schultz, U.S. Government Accounting Office, May 13, 1992, states the disposal phase of TRU containers at the WIPP is 20 years in duration beginning in FY 1998 and continuing through FY 2018 (see Appendix C). According to information provided in the Federal Facility Agreement and Consent Order Change Control Form, M-51-93-01,

January 25, 1994, milestone M-51-03 establishes the initiation of hot operations of the HLW vitrification facility in December of 2009. Milestone M-51-00 completes the vitrification of Hanford high-level tank waste in December of 2028. Imposing the vitrification milestone schedule onto the WIPP waste emplacement schedule, packaged vitrified Hanford TRU waste could be available to be sent to the WIPP during the period of 2010 to 2018.

An unquantified degree of uncertainty exists as to the acceptability of immobilized tank waste to the WIPP. This uncertainty must consider the minimal volume allotted for RH TRU waste disposal at the WIPP repository $\left(7,075 \mathrm{~m}^{3}\right.$, or approximately 5 percent the total volume for waste disposal), the considerable volume of RH TRU glass produced at the Hanford vitrification facility (at least $1,973 \mathrm{~m}^{3}$, or almost 30 percent available volume at the WIPP repository), the lag time between the Hanford vitrification schedule and the WIPP disposal phase, as well as any contractual arrangements that may be necessary before ultimate disposal.

For the cases discussed in Section 5.0, Case 1 campaigns TRU wastes at plant start-up. At the schedule noted above, all TRU waste can be vitrified, packaged, and sent to the WIPP repository by the year 2015 . This leaves the remaining period of 2016 to 2018 , when the repository disposal phase ends, as margin to slip the TRU schedule. Case 2 requires TRU to be processed after a melter changeout. Assuming an average life of a melter as 5 years, the TRU campaign could start by the year 2014. This is a similar schedule as Case 1, however, there is more uncertainty associated with this case since the lifetime of the melter is not known. Case 3 requires processing TRU immediately following the HLW campaign. If the HLW is campaigned at the planned production rate, the TRU campaign could start in the year 2015 or 2016 depending on the type of melter. Since the WIPP waste receiving phase concludes in 2018, no margin exists for schedule slippage. However, operating the 
WHC-SD-WM-ES-386

Revision 0

vitrification plant less than its design capacity during any of the HLW campaign would reduce the volume of RH TRU wastes that could be sent to the WIPP repository since its disposal phase is scheduled to end in 2018.

\subsection{REGULATORY IMPACTS}

It is assumed that the waste package requirements for transportation of RH TRU wastes will be finalized and the RH Cask Safety Analysis Report for Packaging approved by the U.S. Nuclear Regulatory Commission before initiating the TRU campaign.

The TRU concentrations of the three HLW waste types were compared to the acceptance criteria in Waste Acceptance Criteria for the Waste Isolation Pilot Plant, WIPP-DOE-069, Revision 4.0, UC-70, December 1991. The criteria in Paragraph 3.3.6.1 cover the specific activity criteria for acceptance of TRU waste.

For both contact-handled $(\mathrm{CH})$ and $\mathrm{RH}$ waste, a lower limit of $>100 \mathrm{nCi} / \mathrm{g}$ of TRU radionuclides in the waste matrix exists for purposes of TRU waste classification. The radionuclide concentration was determined for the three waste sources and the results are shown below in Table 5-1.

Table 5-1. Minimum Transuranic Activity for Contact-Handled/ Remote-Handled Transuranic Waste Matrix.

\begin{tabular}{|l|c|c|c|}
\hline \multicolumn{1}{|c|}{ Waste source } & $\begin{array}{c}\mathrm{Ci} / \mathrm{m}^{3} \\
\text { (transuranic only) }\end{array}$ & $\mathrm{Ci} / \mathrm{kg}$ & $\mathrm{nCi} / \mathrm{g}$ \\
\hline AW & 1.201 & 0.455 & 455,000 \\
\hline SY & 134.4 & 50.9 & $50,900,000$ \\
\hline T & 4.504 & 1.71 & $1,710,000$ \\
\hline
\end{tabular}

Acceptance Criteria (WIPP, 1991): Must be $>100 \mathrm{nCi} / \mathrm{g}$

The product from each waste source is seen to have a TRU concentration greater than the minimum value of $100 \mathrm{nCi} / \mathrm{g}$, and therefore, each waste product meets this minimum TRU concentration criterium.

The criterion for the maximum activity concentration for a RH TRU waste package is $23 \mathrm{Ci} / \mathrm{L}$. The maximum activities for the three waste sources were calculated, and the results are shown below in Table 5-2. 
Table 5-2. Maximum Activity for Remote-Handled Transuranic Waste Matrix.

\begin{tabular}{|l|c|c|c|}
\hline \multicolumn{1}{|c|}{ Waste source } & Total Ci per canister & $\mathrm{Ci} / \mathrm{m}^{3}$ & $\mathrm{Ci} / \mathrm{L}$ \\
\hline $\mathrm{AW}$ & 157 & 124 & 0.124 \\
\hline $\mathrm{SY}$ & 675 & 536 & 0.536 \\
\hline $\mathrm{T}$ & 129 & 102 & 0.102 \\
\hline
\end{tabular}

Acceptance criterion (WIPP, 1991): cannot exceed $23 \mathrm{Ci} / \mathrm{L}$.

Since the concentrations of the three waste sources do not exceed $23 \mathrm{Ci} / \mathrm{L}$, they each meet this acceptance criterion.

\subsection{SAFETY}

This section evaluates glass waste dose rates and criticality concerns for radionuclide concentrations presented in Appendix A. The glass waste dose rates based on radionuclide concentration are calculated for comparison against the waste acceptance criteria for RH TRU waste. If the dose rate does not initially meet the criteria for RH TRU, the preferred dose rate reduction technique (i.e., reducing the glass waste oxide loading content or increasing the pretreatment DF) will be evaluated. The radionuclide concentrations in various configurations is evaluated to determine the likelihood of criticality occurring in process tanks or the melter.

To perform the various tasks outlined above, three candidate TRU waste tank sources were selected for analysis. Each of these three TRU waste tank sources are presented in Appendix A. The three waste tank sources selected are divided into three streams $(\# 1, \# 344$, and \#441 labeled Feed, HLW, and LLW respectively in Appendix A). For the purposes of this study, only the \#1 and \#344 streams are considered. These combined three tanks and two streams represent six different waste source terms. Stream \#1 (soluble + insoluble) is used for in-facility shielding analysis. Stream \#344 is used to evaluate the HLW glass product for WIPP TRU waste acceptance criteria.

The following paragraphs outline the analysis approach taken for each of the main four tasks and the results.

\subsubsection{Glass Waste Dose}

The first step involved calculating the radiation dose rate at distances of $1 \mathrm{~cm}, 30 \mathrm{~cm}$, and $100 \mathrm{~cm}$ from the outer surface of the glass waste canister for the three types of TRU waste. This analysis determines the "hottest" TRU tank source in the form of the final glass product. 
The next step is to then determine the minimum steel shield thickness on the outside of the HLW steel canister that will provide a dose rate of just less than $200 \mathrm{mrem} / \mathrm{h}$. This shield thickness will then suffice for all of the HLW RH TRU wastes and a standard TRU waste canister can be used.

5.7.1.1 Stream \#1: In-Facility Shielding. Given the relatively low amounts of $\mathrm{Sr} / \mathrm{Y}$ in the four wastes, the shielding radiation dose rates can be well approximated by only the gammaray source spectra. Thus, MicroShield-4.10 is well suited for the shielding analysis for both the stream \#1 feed $\left(0.0038 \mathrm{~m}^{3}\right.$ source $)$, the HLW canister of solid glass and the $1.0 \mathrm{~m}^{3}$ of glass cullet (arbitrary volume). Table 5-3 presents the results of the radiation dose rate calculations for stream \#1 of each of the TRU waste tank sources.

Table 5-3. Feed \#1 Shielding Radiation Dose Rates $\left(0.0038 \mathrm{~m}^{3}\right)$.

\begin{tabular}{|l|l|l|c|c|l|}
\hline \multirow{2}{*}{$\begin{array}{c}\text { Transuranic } \\
\text { waste }\end{array}$} & \multicolumn{5}{|c|}{ Calculated dose rates (mR/h) } \\
\cline { 2 - 6 } & $@ 1 \mathrm{~cm}$ & $@ 30 \mathrm{~cm}$ & $@ 100 \mathrm{~cm}$ & Rank & \multicolumn{1}{|c|}{ Comments } \\
\hline TRU-AW & 1916. & 137.7 & 17.01 & 2 & \\
\hline TRU-SY & 3465. & 250.2 & 30.89 & 1 & Hottest \\
\hline TRU-T & 8.237 & 0.5934 & 0.0733 & 3 & Coldest \\
\hline
\end{tabular}

5.7.1.2 Stream \#344: High-Level Waste. The volume of glass in the HLW canister is $1.26 \mathrm{~m}^{3}$. It is assumed (based on lack of specific finalized HLW canister size and shape) that this $1.26 \mathrm{~m}^{3}$ is in an unshielded HWVP style canister $61-\mathrm{cm}$ O.D. with a $0.95-\mathrm{cm}$ thick stainless steel wall. The glass height is calculated to be such that the HLW solid glass volume is $1.26 \mathrm{~m}^{3}$. The calculation gives a solid glass height of $460.0 \mathrm{~cm}$. Table $5-4$ gives the results of the radiation dose rate analysis.

Table 5-4. Shielding Dose Rates (1.26- $\mathrm{m}^{3}$ Canister).

\begin{tabular}{|l|l|l|l|l|l|}
\hline \multirow{2}{*}{$\begin{array}{c}\text { Transuranic } \\
\text { waste }\end{array}$} & \multicolumn{5}{|c|}{ Calculated dose rates (mR/h) } \\
\cline { 2 - 7 } & @ cm & @ $30 \mathrm{~cm}$ & $@ 100 \mathrm{~cm}$ & Rank & \multicolumn{1}{|c|}{ Comments } \\
\hline TRU-AW & $4,717$. & $2,087$. & 899.1 & 2 & \\
\hline TRU-SY & $11,430$. & $5,058$. & $2,178$. & 1 & Hottest \\
\hline TRU-T & $2,625$. & $1,162$. & 500.3 & 3 & Coldest \\
\hline
\end{tabular}


Based on the above results, the steel shielding that is needed to bring the bare HLW canister to either $200 \mathrm{mrem} / \mathrm{h} @ 1 \mathrm{~cm}$ or $5 \mathrm{rem} / \mathrm{h} @ 100 \mathrm{~cm}$ is calculated for the hottest canister (TRU-SY). Note that the bare canister already meets the railroad dose rate limit of $5 \mathrm{rem} / \mathrm{h}(5,000 \mathrm{mrem} / \mathrm{h})$ at the $100 \mathrm{~cm}$ distance $(2,178 \mathrm{mrem} / \mathrm{h})$.

Therefore, the contact $(1.0 \mathrm{~cm})$ dose rate is calculated to determine the steel shielding required to bring the surface contact dose rate down to $200 \mathrm{mrem} / \mathrm{h}$. The results of the Microshield 4.10 calculations show that about $6.7 \mathrm{~cm}$ thickness of steel shield gives a dose rate of just under $200 \mathrm{mrem} / \mathrm{h}$ at $1.0 \mathrm{~cm}$ from the outer surface of the shield.

\subsubsection{Criticality Concerns}

As part of the vitrification plant studies, the criticality safety of the waste streams from tanks designated as TRU as opposed to HLW tanks was investigated. The three potential waste streams were designated as TRU-AW (NCRW), TRU-SY (PFP), and TRU-T (T201T204). The three waste streams were examined for fissile radionuclides, which are those radionuclides that will fission upon capture of a neutron. The ratio of ${ }^{239} \mathrm{Pu}$ activity (Ci) to the total waste volume was examined for each waste stream. TRU-SY has the greatest ${ }^{239} \mathrm{Pu}$ density ratio while TRU-AW has the lowest ratio (TRU-SY has 17.3 times the ratio of TRUAW). However, TRU-AW has $250 \mathrm{~kg}$ of ${ }^{235} \mathrm{U}\left(26 \mathrm{mt}\right.$ of $\mathrm{UO}_{2}$ enriched to an estimated 1.114 percent) while TRU-SY does not show any ${ }^{235} \mathrm{U}$. The inventory of ${ }^{239} \mathrm{Pu}$ is $17 \mathrm{~kg}$ in TRU-AW and $29.6 \mathrm{~kg}$ in TRU-SY. Therefore, TRU-AW has the greatest fissile inventory and was chosen as the starting basis for the criticality studies.

The total amount of the TRU-AW waste was modeled with MCNP to determine $k_{\text {eff }}$. The waste was placed in a sphere calculated to contain the water. The density was then calculated with the soluble and insoluble components uniformly distributed throughout the sphere. The sphere was then surrounded by a spherical shell of water $2 \mathrm{~m}$ thick to provide neutron reflection. The calculated $k_{\text {eff }}$ was 0.00586 . (Criticality is achieved at a value of 1.00.) Therefore, a criticality problem would not exist using the total TRU-AW waste stream in a worst-case geometry. The possibility of Pu or U concentrating in the glass melter is not addressed in this analysis.

The various waste streams go through a number of processes before ultimately being vitrified into glass. Therefore, a reasonable condition would be to remove water from the waste stream and examine the resulting criticality. Five cases were examined with the remaining percentages of water as $1,10,25,50$, and 75 percent of the water in the initial waste. The spherical radius and density were adjusted as appropriate and presented in Figures 5-1, 5-2, and 5-3 plotting radius versus water content and density versus water content. The volume and density of the sphere were based on the volume of water for all cases except for the 1 percent water. The 1 percent water content case used a spherical radius calculated to give a density of approximately $4.0 \mathrm{~g} / \mathrm{cc}$. All cases used the $2 \mathrm{~m}$. spherical water reflector. The $\mathrm{k}_{\mathrm{eff}}$ for each of the reduced water cases are presented in 
Fgures 5-1, 5-2, and 5-3 labeled Pu Factor $=1$. In all cases, the value of $k_{\text {eff }}$ remained below 0.1 .

One of the constantly fluctuating, and open for debate, items is the source terms in nuclear material processing plants. A further study was conducted using increasing amounts of $\mathrm{Pu}$ in the TRU-AW waste stream since the exact value may be open to debate. This was accomplished by using a Pu Factor greater than one and increasing both the ${ }^{239} \mathrm{Pu}$ and ${ }^{240} \mathrm{Pu}$ contents. The resulting $\mathrm{k}_{\mathrm{eff}}$ calculated values are presented for the various Pu Factors of 1 , $10,100,400$, and 500. As can be seen in the figure, the value of $k_{\text {eff }}$ does not exceed 1.00 until the water content is reduced to 1 percent and the Pu Factor is 400 . A last case with the $\mathrm{Pu}$ Factor of 400 and a 10 percent water content was calculated to establish that the removal of water increased the $k_{\text {eff }}$ value at higher Pu content values.

Within the parameters examined in the referenced study, it does not appear that there is a potential criticality problem with the TRU waste streams. However, if the ${ }^{239} \mathrm{Pu}$ or ${ }^{235} \mathrm{U}$ contents significantly increase or the water content is drastically reduced, the criticality of the configuration should be revisited in a more specific criticality analysis.

\subsection{COST IMPACT}

This section describes the methodology for preparing the capital cost analysis for the TRU processing in the HLW vitrification facility. This analysis was performed to aid in the evaluation of the feasibility of processing transuranic wastes as a separate campaign in the HLW vitrification facility. An analysis of life-cycle cost is reported in the Cost Benefit Analysis of Transuranic Tank Waste Disposal (Crawford et al. 1996).

\subsubsection{Capital Costs}

Facility modifications, as discussed in Section 4.2.3, are not expected to have significant costs associated with the glass campaign conversion. Hardware items required to be replaced (e.g., weld head, transfer carts) are expected to total less than a percent of the direct costs of the reference facility. Additionally, storage pad costs are not expected to change significantly with the modified reference plant since the RH TRU canister overpacks are required to be transferred to the WIPP during the time period discussed in Section 5.5. An allowance of $\$ 1$ million in direct costs plus construction management, project management, contingency, and engineering was made to cover the capital cost of the conversion. The total capital cost is rounded to $\$ 2$ million.

The cost analysis assumed that TRU would be processed before HLW processing begins. This scenario is considered to have the least capital cost for conversion of the three cases considered. 


\section{WHC-SD-WM-ES-386}

Revision 0

Figure 5-1. Water Content Density Dependency.

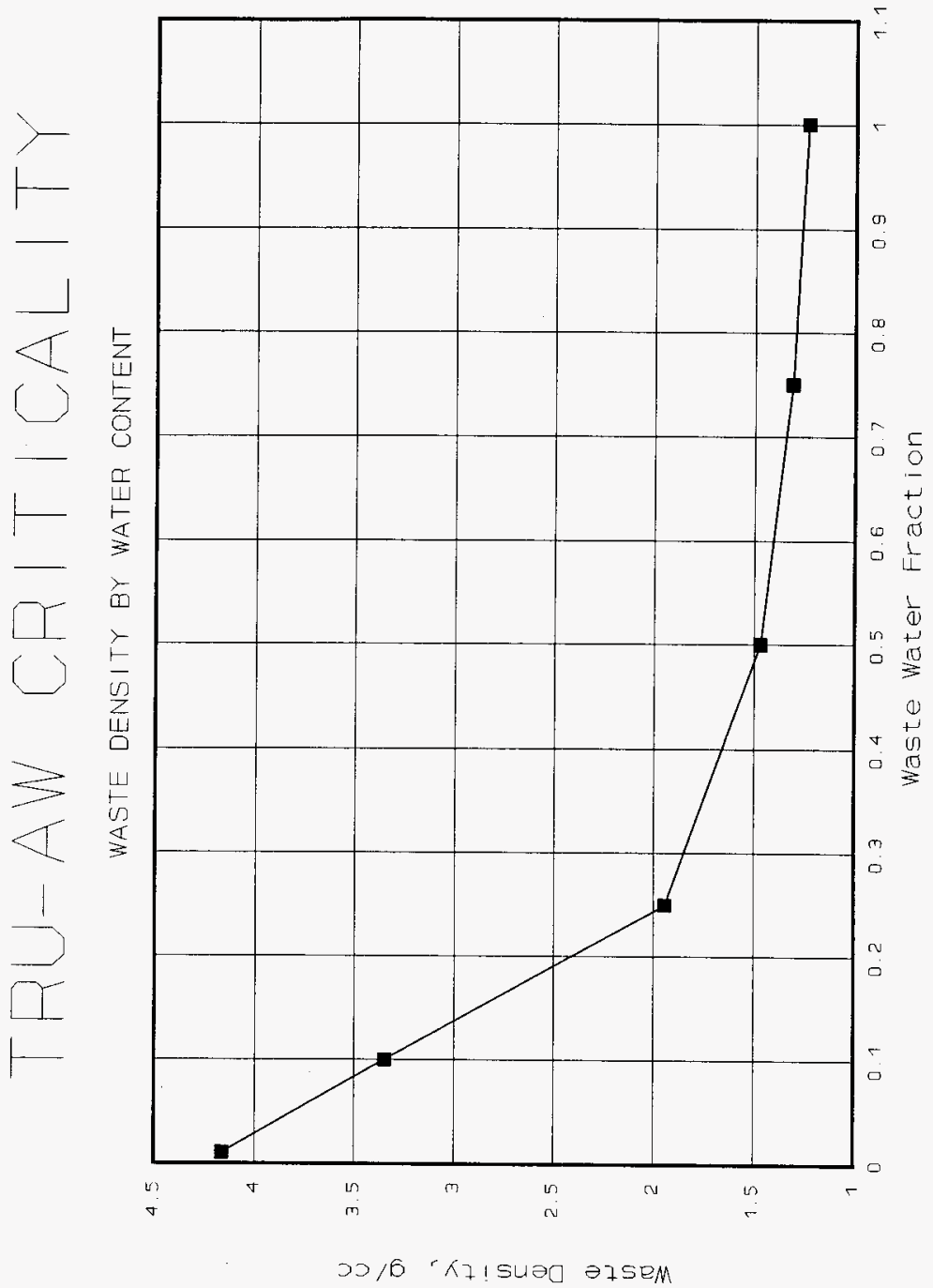


WHC-SD-WM-ES-386

Revision 0

Figure 5-2. Sphere Radius Dependency.

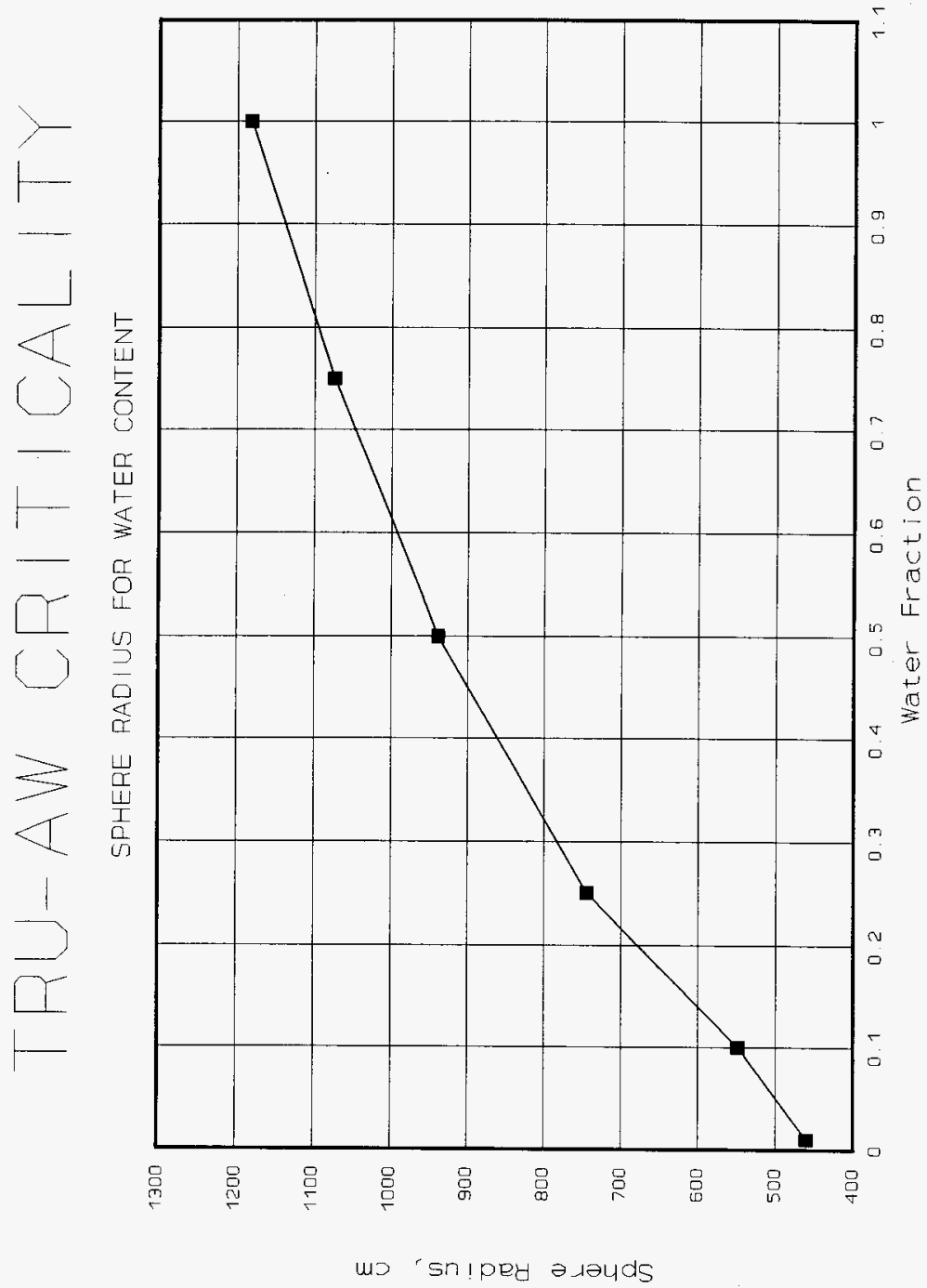


WHC-SD-WM-ES-386

Revision 0

Figure 5-3. Criticality Dependency.

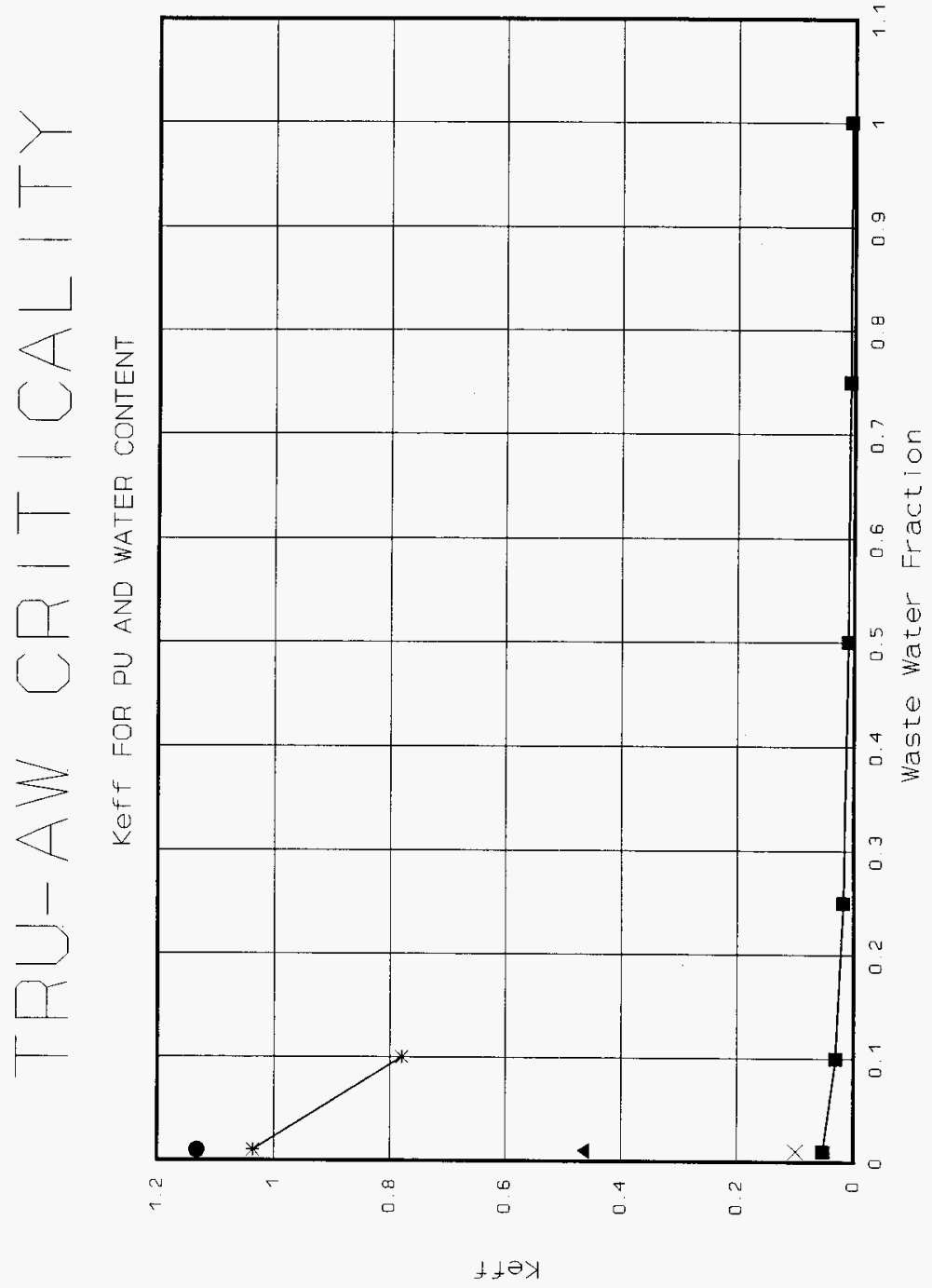




\subsubsection{Container Costs}

Canister, overpack, and cask costs are summarized in Table 5-5 for both HLW containers and TRU containers. All containers are estimated on a fabricated per mass basis in 1994 dollars. Stainless steel containers are estimated at $\$ 10.45$ per kilogram; carbon steel containers are estimated at $\$ 3.48$ per kilogram; and concrete containers are estimated at $\$ 1.10$ per kilogram. Allowances for such as contingency, project management, and construction management are included in the unit material prices. State tax of 7.8 percent is added to the total.

Table 5-5. High-level Waste and Transuranic Container Costs.

\begin{tabular}{|l|c|c|c|c|}
\hline \multicolumn{1}{|c|}{ Waste form container } & $\begin{array}{c}\text { Stainless } \\
\text { steel wt. } \\
\text { MT }\end{array}$ & $\begin{array}{c}\text { Carbon } \\
\text { steel wt. } \\
\text { MT }\end{array}$ & $\begin{array}{c}\text { Concrete } \\
\text { wt. MT }\end{array}$ & $\begin{array}{c}\text { Unit price } \\
\text { each }\end{array}$ \\
\hline $\begin{array}{l}\text { High-level waste } \\
\text { containers (4-packs) }\end{array}$ & 9.64 & N/A & 90.0 & $\$ 215,000$ \\
\hline Transuranic containers & 0.4 & 0.4 & 36.0 & $\$ 48,700$ \\
\hline
\end{tabular}




\subsection{REFERENCES}

Boomer, K. D., J. M. Colby, T. W. Crawford, J. S. Garfield, J. D. Galbraith, C. E. Golberg, C. E. Leach, D. E. Mitchell, F. D. Nankani, E. J. Slaathaug, L. M. Swanson, T. L. Waldo, and C. M. Winkler, 1994, Tank Waste Remediation System Facility Configuration Study, WHC-ED-WM-ES-295, Rev. 0, Westinghouse Hanford Company, Richland, Washington.

Crawford, T. W. and C. M. McConville, 1996, Decision Document for Transuranic Tank Waste Disposal, WHC-SD-WM-ES-368, Rev. 0, Westinghouse Hanford Company, Richland, Washington.

Ecology, EPA, and DOE, 1994, Hanford Federal Facility Agreement and Consent Order, as amended, Washington State Department of Ecology, U.S. Environmental Protection Agency, and the U.S. Department of Energy, Olympia, Washington.

Orme, R. M., 1995, TWRS Process Flowsheet, WHC-SD-WM-TI-613, Rev. 1, Westinghouse Hanford Company, Richland, Washington.

Resource Conservation and Recovery Act of 1976, 42 USC 6901 et seq.

Crawford, T. W., 1995, Alternatives for High-Level Waste Forms, Containers, and Container Processing Systems, WHC-SD-WM-ES-348, Rev. 0, Westinghouse Hanford Company, Richland, Washington.

WIPP, 1991, Waste Acceptance Criteria for the Waste Isolation Pilot Plant, WIPP-DOE-069, Revision 4.0, UC-70, Carlsbad, New Mexico. 
WHC-SD-WM-ES-386

Revision 0

APPENDIX A

TRANSURANIC WASTE VOLUME

PROJECTIONS (REVISION 2)

A-1 
WHC-SD-WM-ES-386

Revision 0

This page intentionally left blank. 
WHC-SD-WM-ES-386

Revision 0

Westinghouse

Internal Hanford Company

Memo

From: TWRS Process Engineering

Phone: $376-2279$ H5-49

Date: March 19, 1996

Subject: TRU WASTE VOLUME PROJECTIONS - REVISION 2

74A20-96-001

To:

T. W. Crawford

W. J. Powel 1

H5-49

H5- 49

cc: w/o attachments

A. L. Boldt H5-49

K. D. Boomer H5-61

J. S. Garfield H5-49

A. F. Manuel H5-49

J. P. Sloughter R2-54

AFM File/LB

References: (1) Internal Memo, L. W. Shelton to R. M. Orme, "Chemical and Radionuciide Inventory for Single and Double-Shell Tanks," dated August 7, 1995.

(2) WHC-SD-WM-TI-613, TWRS Process Flowsheet, Revision 1, dated August $14,1995$.

(3) WHC-SD-HWV-DP-001, Hanford Waste Vitrification Plant Project Technical Data Package, Revision 6, dated February 1994.

(4) PNL-10359, Property/Composition Relationships for Hanford High-Level Waste Glasses Melting at $1150^{\circ} \mathrm{C}$, Volume 1, dated December 1994.

(5) RHO-SD-WM-T1-057, Preliminary Estimation of the Waste Inventories in Hanford Tanks Through 1980, Revision 0-A, dated October 13, 1993.

As requested, mass balance calculations using Revision 1 of the IWRS Process Flowsheet (Reference 2) and current chemical and radionuclide inventory assumptions (Reference 1) have been performed for the tank waste inventories of 10 tanks which have been identified to contain transuranic (TRU) wastes. These wastes are being evaluated for their potential for disposa? at the Waste Isolation Pilot Plant (WIPP) as an alternative to the high-level waste (HLW) repository. To assist in this evaluation, calculations of $H L W$ and low-level waste (LLW) volumes have been performed. 
Revision 0

T. W. Crawford

74A20-96-001

W. J. Powell

Page 2

March 19, 1996

The contents of three double-shell tanks (DSTs) and seven single-shell tanks (SSTS) have been identified as TRU wastes:

$\begin{array}{llll}241-A W-103 & 241-T-110 & 241-T-201 & 241-T-204 \\ 241-A W-105 & 241-T-111 & 241-T-202 & \\ 241-S Y-102 & 241-T-112 & 241-T-203 & \end{array}$

Process flowsheet simulation runs are performed for 4 different tank groupings :

1) the total blend (177 tanks);

2) the 10 TRU tanks blended together;

3) the 10 TRU tanks blended into 3 blends by farm; and

4) the blend of the remaining 167 non-TRU tanks.

Each blend is run through 4 different HLW glass formulations (see Model Assumptions below). Estimates of immobilized $H L W$ and $L L W$ volumes and compositions produced by the Tank Waste Remediation system (TWRS) are provided for each of these blends.

Chemical and Radionuclide Inventory Assumptions

(1) SST chemical inventory assumptions as of August 7, 1995, including the Los Alamos National laboratory (LANL) update for chemicals normalized to the 1985 Hanford Defense Waste Environmental Impact Statement (EIS) totals (Reference 1);

(2) DST chemical inventory estimates based upon analytical data from Tank Characterization Reports (Reference 1) and additional inventory assumptions as of August 7, 1995;

(3) Radionuclide inventories for both SSTs and DSTs based upon Track Radioactive Components (TRAC) data and analytical data sources including Tank Characterization Reports (Reference 5);

(4) Miscellaneous facility waste input streams are not included in these projections. 


\section{Revision 0}

T. W. Crawford

74A20-96-001

W. J. Powe11

Page 3

March 19, 1996

\section{Flowsheet Model Assumptions}

(1) Tank waste batches are processed through Revision 1 of the TWRS Process Flowsheet model (Reference 2);

(2) In the "baseline" case, the Hanford Waste Vitrification Plant (HWVP) glass formulation for $\mathrm{HLW}$ glass melting below $1150^{\circ} \mathrm{C}$ (Reference 3 ) is assumed. These composition criteria are also referred to as low temperature HWV glass limits and are identical to the baseline assumptions for HLW vitrification used in the TWRS Process Flowsheet;

(3) As an alternative, flowsheet cases are included using the composition Variation Study (CVS) glass composition region of testing for HLW glass melting at $1150{ }^{\circ} \mathrm{C}$ (Reference 4 ) and are referred to as low temperature CVS glass limits. A separate evaluation has yet to be conducted to evaluate the physical properties of the glass formulations calculated in this study. The CVS limits are planned to be included in a future revision of the flowsheet;

(4) Two additional TRU cases are run using HLW glass formulations which satisfy only the minimum composition requirements for $\mathrm{B}_{2} \mathrm{O}_{3}, \mathrm{Li}_{2} \mathrm{O}$, and $\mathrm{SiO}_{2}$. In other words, only the lower composition constraints in Table A-1 are satisfied for the HWVP and CVS cases. These cases are run to determine the sensitivity of TRU waste glass volumes on the selected glass formulation. Since WIPP has less constraining waste form requirements than the HLW repository, a glass formulation producing less glass may be possible. This assumes an acceptable glass product viscosity and easy removal from the melter.

(5) The alternative glass formulation assumptions for the HWVP and CVS low temperature melters are summarized in Table A-1. 
T. W. Crawford

W. J. Powell

Page 4

March 19, 1996
WHC-SD-WM-ES-386

Revision 0

Table A-1. Low Temperature High-Level Waste Glass Formulations.

\begin{tabular}{|c|c|c|c|c|}
\hline & \multicolumn{2}{|c|}{ HWVP Limits $\left(<1150^{\circ} \mathrm{C}\right)$} & \multicolumn{2}{|c|}{ CVS Limits $\left(1150{ }^{\circ} \mathrm{C}\right)$} \\
\hline Oxide Component & Lower Limit & Upper Limit & Lower Limit & Upper Limit \\
\hline \multicolumn{5}{|c|}{ Single-Component Constraints } \\
\hline $\mathrm{SiO}_{2}$ & 46.0 & 56.0 & 42.0 & 57.0 \\
\hline $\mathrm{B}_{2} \mathrm{O}_{3}$ & 7.0 & 17.0 & 5.0 & 20.0 \\
\hline $\mathrm{Na}_{2} \mathrm{O}+\mathrm{K}_{2} \mathrm{O}$ & 7.0 & 12.5 & 5.0 & 20.0 \\
\hline $\mathrm{Li}_{2} \mathrm{O}$ & 2.0 & 6.0 & 1.0 & 7.0 \\
\hline $\mathrm{CaO}$ & 0.0 & 7.0 & 0.0 & 10.0 \\
\hline $\mathrm{MgO}$ & 0.0 & 5.0 & 0.0 & 8.0 \\
\hline $\mathrm{Fe}_{2} \mathrm{O}_{3}$ & 4.0 & 12.0 & 2.0 & 15.0 \\
\hline $\mathrm{Al}_{2} \mathrm{O}_{3}$ & 1.0 & 11.0 & 0.0 & 15.0 \\
\hline $\mathrm{ZrO}_{2}$ & -- & 10.0 & -- & 13.0 \\
\hline Others & 2.5 & 8.0 & 1.0 & 10.0 \\
\hline \multicolumn{5}{|c|}{ Multiple-Component Constraints } \\
\hline $\begin{array}{l}\text { Viscosity: } \\
\left(\mathrm{Li}_{2} \mathrm{O}+\right. \\
\left.\mathrm{Na}_{2} \mathrm{O}\right) / \mathrm{SiO}_{2}+ \\
\left.\mathrm{Al}_{2} \mathrm{O}_{3}+\mathrm{ZrO}_{2}\right) \\
\end{array}$ & 0.152 & 0.342 & 0.152 & 0.342 \\
\hline \multicolumn{5}{|l|}{ Crystallinity: } \\
\hline $\mathrm{SiO}_{2} / \mathrm{Al}_{2} \mathrm{O}_{3}$ & 4.5 & 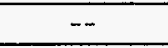 & 3.0 & - \\
\hline $\mathrm{MgO}+\mathrm{CaO}$ & -- & 8.0 & -- & 10.0 \\
\hline $\mathrm{Al}_{2} \mathrm{O}_{3}+2 \mathrm{ZrO}_{2}$ & -- & 14.0 & -- & 16.0 \\
\hline $\begin{array}{l}\mathrm{Fe}_{2} \mathrm{O}_{3}+\mathrm{Al}_{2} \mathrm{O}_{3}+ \\
\mathrm{ZrO}_{2}+\text { Others }\end{array}$ & $\overline{--}$ & 21.0 & $\overline{--}$ & 24.0 \\
\hline \multicolumn{5}{|c|}{ Solubility Limits } \\
\hline $\mathrm{Cr}_{2} \mathrm{O}_{3}$ & -- & 0.5 & -- & 0.5 \\
\hline $\mathrm{F}$ & -- & 1.7 & - & 1.7 \\
\hline $\mathrm{P}_{2} \mathrm{O}_{5}$ & - & 1.0 & -- & 1.0 \\
\hline $\begin{array}{l}\mathrm{Rh}_{2} \mathrm{O}_{3}+\mathrm{PdO}+ \\
\mathrm{Ru}_{2} \mathrm{O}_{3}\end{array}$ & -- & 0.25 & $\overline{--}$ & 0.25 \\
\hline $\mathrm{SO}_{3}$ & -- & 0.5 & - & 0.5 \\
\hline \multicolumn{5}{|c|}{ Redox constraints } \\
\hline $\begin{array}{l}\text { Reductants } \\
\text { (formic acid, } \\
\text { oxalic acid, and } \\
\text { sugar) }\end{array}$ & TBD & -- & TBD & $\overline{--}$ \\
\hline
\end{tabular}


T. W. Crawford

W. J. Powell

Page 5

March 19, 1996
WHC-SD-WM-ES-386

Revision 0

\section{Conclusions}

Alternative HLW glass formulations for the processing of TRU waste streams could lead to significant reductions in glass volumes. The most significant reductions occur when only the lower limits for $\mathrm{SiO}_{2}, \mathrm{~B}_{2} \mathrm{O}_{3}$, and $\mathrm{Li}_{2} \mathrm{O}$ are used in the glass formulation. For the TRU blended case, a reduction in TRU glass volume of $31 \%$ is possible using a glass formulation which meets only the minimum composition constraints for the vitrified HLW. Glass volumes may be reduced even further if the minimum limits for the CVS glass composition region (low temperature melter) are utilized, resulting in a $41 \%$ decrease from the baseline case (see Table 1).

Blending of TRU wastes could also decrease TRU glass volumes. In the baseline case (HWVP limits), the volume of glass can be expected to decrease $35 \%$ if the TRU tanks are blended together rather than processed by farm. A complete blend of TRU waste would require the consolidation of approximately 280,000 gallons of washed solids. The effects of blending will be less pronounced if one of the alternative glass formulations is used.

If desired, the tables can be revised for issuance at a later date as new information becomes available. Please contact me at (509) 376-2279 if you have any questions.<smiles>CCCCCCCCCCCCCCCCCCCCCCCC</smiles>

Anthony F. Manuel, Engineer TWRS Process Engineering

Attachments (2)

$\mathrm{afm}$ 
WHC-SD-WM-ES-386

Revision 0

This page intentionally left blank.

A-8 


\title{
WHC-SD-WM-ES-386
}

Revision 0

74A20-96-001

ATTACHMENT 1

TRU WASTE VOLUME PROJECTIONS (REVISION 2)

\author{
HLW and LLW Glass Volume Production Summary Table \\ Low Temperature HWVP Glass Formulation \\ Low Temperature HWVP Glass Formulation (Lower Limits Only) \\ Low Temperature CVS Glass Composition \\ Low Temperature CVS Glass Composition (Lower Limits Only) \\ Consisting of 13 pages
}


WHC-SD-WM-ES-386

Revision 0

This page intentionally left blank. 
Table 1. Projected HLWLLW Glass Production from TRU Waste - Large Canlster (1.26-m') Equivalents

\begin{tabular}{|c|c|c|c|c|c|c|c|c|c|c|c|c|c|c|c|}
\hline \multirow{3}{*}{ 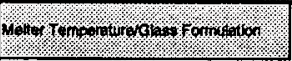 } & \multirow{2}{*}{\multicolumn{5}{|c|}{ 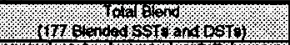 }} & \multirow{2}{*}{\multicolumn{5}{|c|}{ Vonving }} & \multirow{2}{*}{\multicolumn{5}{|c|}{ 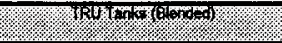 }} \\
\hline & & & & & & & & & & & & & & & \\
\hline & HEW & WOL & 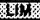 & $\% 60$ & GW & $\mathrm{SHCH}$ & WOE & KLIM & S6G14 & SGK & 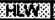 & KOE & 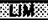 & 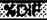 & 1 \\
\hline $\begin{array}{l}\text { Low }\left(<1150^{\circ} \mathrm{C}\right) \text { HWW Limits (Base Case) } \\
\text { High }\left(>1150^{\circ} \mathrm{C}\right) \text { CVS Limits } \\
\text { Low }\left(<1150^{\circ} \mathrm{C}\right) \text { Lower Limits Only } \\
\text { High }\left(>1150^{\circ} \mathrm{C}\right) \text { Lower Limits Only }\end{array}$ & $\begin{array}{c}6,660 \\
5,940 \\
-\end{array}$ & $\begin{array}{c}51 \% \\
59 \% \\
\ldots\end{array}$ & $\begin{array}{l}\text { Frit } \\
\text { Frit } \\
-\end{array}$ & $\overline{13 \%}$ & $\begin{array}{c}43.2 \\
43.2 \\
- \\
-\end{array}$ & $\begin{array}{c}6,150 \\
5,310 \\
\ldots \\
\ldots\end{array}$ & $\begin{array}{l}52 \% \\
60 \% \\
-\end{array}$ & $\begin{array}{c}\text { Frit } \\
\text { Fint } \\
- \\
-\end{array}$ & $\overline{14 \%}$ & $\begin{array}{c}42.1 \\
42.1 \\
- \\
-\end{array}$ & $\begin{array}{l}1,029 \\
791 \\
707 \\
609\end{array}$ & $\begin{array}{l}32 \% \\
42 \% \\
45 \%\end{array}$ & $\begin{array}{l}\mathrm{ZrO} \\
\mathrm{ZrO}_{2} \\
\mathrm{Frit} \\
\mathrm{Frit}\end{array}$ & $\begin{array}{l}\overline{23 \%} \\
31 \% \\
41 \%\end{array}$ & $\begin{array}{l}1.2 \\
1.2 \\
1.2 \\
1.2\end{array}$ \\
\hline
\end{tabular}

\begin{tabular}{|c|c|c|c|c|c|c|c|c|c|c|c|c|c|c|c|c|c|c|c|c|}
\hline \multirow{2}{*}{ 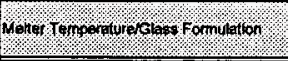 } & \multicolumn{5}{|c|}{ TRUTanks in AW Farm } & \multicolumn{5}{|c|}{ 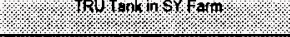 } & \multicolumn{5}{|c|}{ 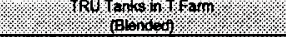 } & \multicolumn{5}{|c|}{ 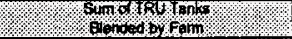 } \\
\hline & HEW & WOK & बIM & 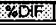 & tow & माEW & WOL & EMM: & KOAF & HWW & MIUW & Tat & BM\% & XEIT & Un & BIEW & Koㅇ & Gin & XOAP & UIW \\
\hline Low (c1150"C) HWVP Limits (Base Case) & 1,030 & $19 \%$ & $\mathrm{ZrO}_{2}$ & - & 0.6 & 177 & $18 \%$ & $\mathrm{Cr}^{2} \mathrm{O}_{3}$ & - & 0.1 & 370 & $\mathbf{3 0 \%}$ & $\mathrm{P}_{2} \mathrm{O}_{8}$ & - & 0.5 & 1,577 & $21 \%$ & N/A & - & 1.2 \\
\hline High $\left(>1150^{\circ} \mathrm{C}\right)$ CVs Limits & 791 & $24 \%$ & $\mathrm{ZnO}_{2}$ & $23 \%$ & 0.6 & 177 & $18 \%$ & $\mathrm{Cl}_{2} \mathrm{O}_{3}$ & $0 \%$ & 0.1 & 370 & $30 \%$ & $\mathrm{P}_{2} \mathrm{O}_{8}$ & $0 \%$ & 0.5 & 1,337 & $25 \%$ & N/A & $15 \%$ & 1.2 \\
\hline Low (<1150"C) Lower Limits Only & 456 & $42 \%$ & Firit & $56 \%$ & 0.6 & 62 & $51 \%$ & Frit & $65 \%$ & 0.1 & 237 & $46 \%$ & Frit & $36 \%$ & 0.5 & 755 & $44 \%$ & NA & $52 \%$ & 1.2 \\
\hline High (>1150 C) Lower Limils Only & 370 & $52 \%$ & Frit & $64 \%$ & 0.6 & 54 & $59 \%$ & Frit & $70 \%$ & 0,1 & 198 & $55 \%$ & Frit & $46 \%$ & 0.5 & 622 & $53 \mathbf{x}$ & N/A & E1\% & 1.2 \\
\hline
\end{tabular}

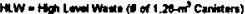

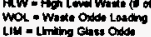

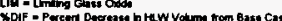

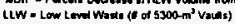

Table 2. Projected HLW \& TRU Glass Production from Segregating TRU Tank Waste - Large HLW Canlsters and Small RH-TRU Canisters

\begin{tabular}{|c|c|c|c|c|c|c|c|}
\hline \multirow[b]{2}{*}{ 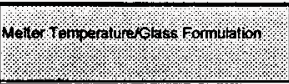 } & \multicolumn{2}{|c|}{ A d HLW Wanisiers (1) } & \multicolumn{5}{|c|}{ 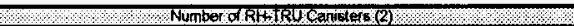 } \\
\hline & (Bofos casp) & $\begin{array}{l}\text { Remahing } \\
\text { Tontrous }\end{array}$ & TRUThanks & AW Wain & TrkJ & 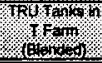 & Sum ofhu \\
\hline $\begin{array}{l}\text { Low (c1150"C) HWWP Limits (Base Case) } \\
\text { High }\left(>1150^{\circ} \mathrm{C}\right) \text { CVS Limits } \\
\text { Low }\left(<1150^{\circ} \mathrm{C}\right) \text { Lower Limits Only } \\
\text { High }\left(>1150^{\circ} \mathrm{C}\right) \text { Lower Limits Oniy }\end{array}$ & $\begin{array}{l}6,860 \\
5,940 \\
= \\
-\end{array}$ & $\begin{array}{l}6,150 \\
5,310 \\
= \\
-\end{array}$ & $\begin{array}{l}1,627 \\
1,403 \\
1,255 \\
1,060\end{array}$ & $\begin{array}{l}1,828 \\
1,403 \\
810 \\
657\end{array}$ & $\begin{array}{l}313 \\
313 \\
110 \\
95\end{array}$ & $\begin{array}{l}657 \\
657 \\
420 \\
352\end{array}$ & $\begin{array}{l}2,798 \\
2,373 \\
1,341 \\
1,104\end{array}$ \\
\hline
\end{tabular}

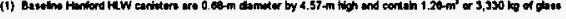

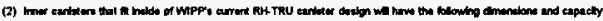

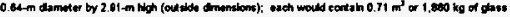

Table 3. Projected HLW \& TRU Glass Production from Segregating TRU Tank Waste - Glass Volumes

\begin{tabular}{|c|c|c|c|c|c|c|c|c|c|}
\hline \multirow[b]{2}{*}{ 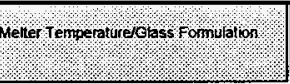 } & \multicolumn{2}{|c|}{ HW Glass Volume (m) } & \multicolumn{5}{|c|}{ RHTRU Gla6s Volume (m) } & \multirow[b]{2}{*}{ 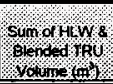 } & \multirow[b]{2}{*}{ sumothows } \\
\hline & Toral Bend & 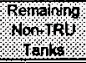 & (Biendrad) & 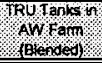 & $\begin{array}{l}\text { TRU Tankin } \\
\text { (Etenderi) }\end{array}$ & 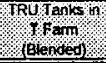 & 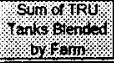 & & \\
\hline $\begin{array}{l}\text { Low }\left(c 1150^{\circ} \mathrm{C}\right) \text { HWVP Limits (Base Case) } \\
\text { High }\left(>1150^{\circ} \mathrm{C}\right) \text { CVS Limits } \\
\text { Low }\left(<1150^{\circ} \mathrm{C}\right) \text { Lower Limits Only } \\
\text { High }\left(>1150^{\circ} \mathrm{C}\right) \text { Lower Limits Only }\end{array}$ & $\begin{array}{c}8,644 \\
7,484 \\
- \\
-\end{array}$ & $\begin{array}{c}7,749 \\
6,691 \\
- \\
-\end{array}$ & $\begin{array}{l}1,297 \\
996 \\
891 \\
767\end{array}$ & $\begin{array}{l}1,298 \\
996 \\
\mathbf{5 7 5} \\
466\end{array}$ & $\begin{array}{l}223 \\
223 \\
78 \\
68\end{array}$ & $\begin{array}{l}456 \\
466 \\
298 \\
250\end{array}$ & $\begin{array}{l}1,987 \\
1,685 \\
952 \\
764\end{array}$ & $\begin{array}{l}9,046 \\
7,687 \\
8,640 \\
7,458\end{array}$ & $\begin{array}{l}9,736 \\
8.376 \\
8,701 \\
7,474\end{array}$ \\
\hline
\end{tabular}


Revision 0

Table 2. TRU Waste Volume Projections (Rev. 2) - Low Temperature Glass Formulation

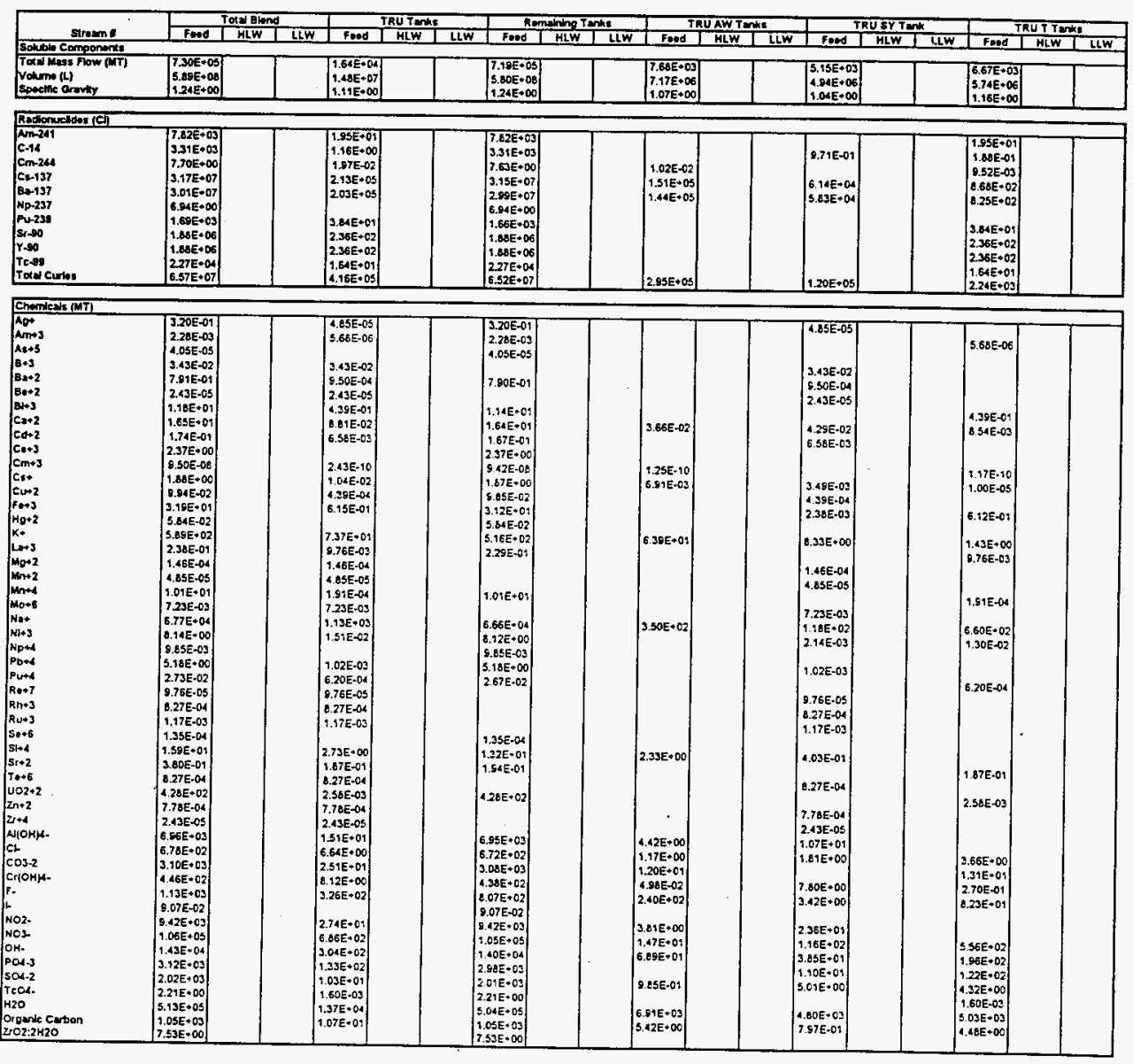




\begin{tabular}{|c|c|c|c|c|c|c|c|c|c|c|c|c|c|c|c|c|c|c|}
\hline \multirow{2}{*}{ Sream } & \multicolumn{3}{|c|}{ Tote bitend } & \multicolumn{3}{|c|}{ TRu forkt } & \multicolumn{3}{|c|}{ Merraning Tank } & \multicolumn{3}{|c|}{ TRUAW Tanks } & \multicolumn{3}{|c|}{ TRU EYTAN } & \multicolumn{3}{|c|}{ JRU T T Mak: } \\
\hline & Foed I & I HEW I & LLW & Fond & \multirow{2}{*}{$\mid$ ILW } & ILIW & Fond I & \multicolumn{2}{|c|}{ HLW I LLW } & Foed & \multirow{2}{*}{\multicolumn{2}{|c|}{$I_{\text {HLW I LW }}$}} & \multirow{2}{*}{ Foed } & \multirow{2}{*}{$\begin{array}{l}\mid \mathrm{HLW} \\
592 \mathrm{~W}-02\end{array}$} & \multirow{2}{*}{ ILLW } & \multirow{2}{*}{$\begin{array}{l}\text { Fend } \\
.57 \mathrm{E}+02\end{array}$} & \multirow{2}{*}{\multicolumn{2}{|c|}{ 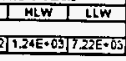 }} \\
\hline & $x=1$ & & & (1) & & $9,61 E \cdot 0$ & TE & DEE:04 & $75.3+2+0$, & D.S3E+02 & & & & & & & & \\
\hline \multicolumn{19}{|l|}{ tornectil } \\
\hline & & 0.6 & $0.10 E+03$ & का & $1.17 E+0.4$ & 1.75E+02 & & $\sqrt{0.43 E+0.4}$ & $0.94 \mathrm{E}+03$ & $3.50 E+02$ & $3.45 E+C 2$ & 2] & $E \div 04$ & $\pi$ & $1.40 E+02$ & & a & $\sqrt{1}$ \\
\hline 24 & $2.19 E+03$ &, $40 E+03$ & & $\mid \begin{array}{l}2.15 E-01 \\
2.55 E=01\end{array}$ & 2 291E+01 & $\log _{5-01}$ & & & & & & & 2.13E-09 & & & & & \\
\hline $\begin{array}{l}c-244 \\
c_{1}-1337\end{array}$ & $3.01 E+06$ & $3.44 E+07$ & 3.08E.05 & $\mid \begin{array}{l}2.93 E+01 \\
1.53 E+05\end{array}$ & $\mid \begin{array}{l}2.91 E+04 \\
1.52 E \cdot 05\end{array}$ & $3.78 E+63$ & $\mid \begin{array}{c}1.39 \mathrm{E} \cdot 03 \\
2.06 \mathrm{E} \cdot 06\end{array}$ & $\begin{array}{l}3+.28 E+3 \\
3.43 E+07\end{array}$ & 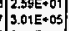 & & $\mid \begin{array}{l}6.52 E-05 \\
1.50 E+05\end{array}$ & $\left|\begin{array}{c}0.01 E-02 \\
3.25 E+03\end{array}\right|$ & $\left|\begin{array}{l}2.86 E+01 \\
920 E+02\end{array}\right|$ & $\left|\begin{array}{l}2.83 E+01 \\
1.04 E+03\end{array}\right|$ & $\mid \begin{array}{l}3.76 E-01 \\
5.25 E \cdot 02\end{array}$ & $\mid \begin{array}{l}9.45 E \cdot 09 \\
2.89 E+02\end{array}$ & $\begin{array}{l}5.33 E-09 \\
2.89 E+02\end{array}$ & $\mid \begin{array}{l}2.19 E-02 \\
1.10 E+01\end{array}$ \\
\hline $\begin{array}{l}B x-137 \\
\text { Np-237 }\end{array}$ & $\left|\begin{array}{l}2.86 E+08 \\
6.27 E+09\end{array}\right|$ & $\left|\begin{array}{l}3.27 E * 07 \\
6.19 E+01\end{array}\right|$ & $\left|\begin{array}{l}2.90 E * 05 \\
7.76 E+00\end{array}\right|$ & $1,45 E \cdot 0 S$ & $1,44 E<05$ & $3.60 \mathrm{E}+0.3$ & $\left|\begin{array}{l}2.72 E+06 \\
627 E+0.1\end{array}\right|$ & $\left|\begin{array}{l}3.24 E+07 \\
6.49 E+01\end{array}\right|$ & $2.86 E+05$ & $1.44 E+0 S$ & $1.43 E+05$ & $3.08 E+03$ & $8.74 E * 02$ & S.E3E*02 & $4.99 E \cdot 02$ & $2.74 E-02$ & 2 & $\begin{array}{l}1.70 E+010 \\
1.03 E+01\end{array}$ \\
\hline $\begin{array}{l}-239 \\
-240\end{array}$ & $\begin{array}{l}2.46 E+04 \\
626 E+03\end{array}$ & $\begin{array}{l}2.44 \mathrm{E} \cdot 04 \\
6.57+09\end{array}$ & $\begin{array}{l}2.02 E+03 \\
8.7 E+01\end{array}$ & $5.18 E+03$ & $5.11 E \cdot 03$ & $1.06 E=02$ & $1.96 E+04$ & $1.93 E \cdot 04$ & & $1.22 \mathrm{E} * 03$ & $1.20 E+03$ & $1.60 E-01$ & $2.08 E+03$ & $3.05 E+03$ & $2.73 E+01$ & $B B E-03$ & $1.66 E+03$ & $6.30 \mathrm{E} \cdot 0 \mathrm{~s}$ \\
\hline-241 & $E \rightarrow \infty$ & $6.86 \mathrm{E}+0 \mathrm{~s}$ & $9.14 \mathrm{E}$ & & & & G.SSE+04 & $|8.06 E+0.01|$ & $\left|\begin{array}{l}0.24 E-14 \\
0.14 E+08\end{array}\right|$ & & & & & & & & & \\
\hline & & $5.13 E+07$ & 2.37 & $1.49 E+05$ & $\mid 9.18 E+05$ & $1.78 E+03$ & $5.17 E+07 \mid$ & $|5.12 E+07|$ & $2.37 E+D 6$ & & $x$ & & & & & & & \\
\hline & & & & & $\mid 1.18 E+05$ & $1.70 E=03$ & & & & & & & $=4$ & +04 & & & & \\
\hline e-9s & & $\left|\begin{array}{l}5.12 E+03 \\
1.70 E+08\end{array}\right|$ & $\begin{array}{l}2.20 E+00 \\
5.37 E+06\end{array}$ & $\left|\begin{array}{l}6.44 E+01 \\
3.53 E+05\end{array}\right|$ & $\left|\begin{array}{l}4.33 E+01 \\
3.4 B E+05\end{array}\right|$ & $\begin{array}{r}1,69 \mathrm{E}-01 \\
1.12 \mathrm{E}+0 \mathrm{Da}\end{array}$ & $\left|\begin{array}{c}0.23 E+03 \\
3.09 E+08\end{array}\right|$ & $\left|\begin{array}{l}0.03 E+02 \\
1.69 E+00\end{array}\right|$ & $\mid \begin{array}{l}2.28 \mathrm{E}+04 \\
5.36 \mathrm{E}+06\end{array}$ & $=+0$ & $3,95 E+05$ & - & $2.60 \mathrm{E}+01$ & 2.7 & -01 & $E=01$ & $1.60 \mathrm{E}=01$ & \\
\hline & & & & & & & & & & & & & & & & & & \\
\hline
\end{tabular}

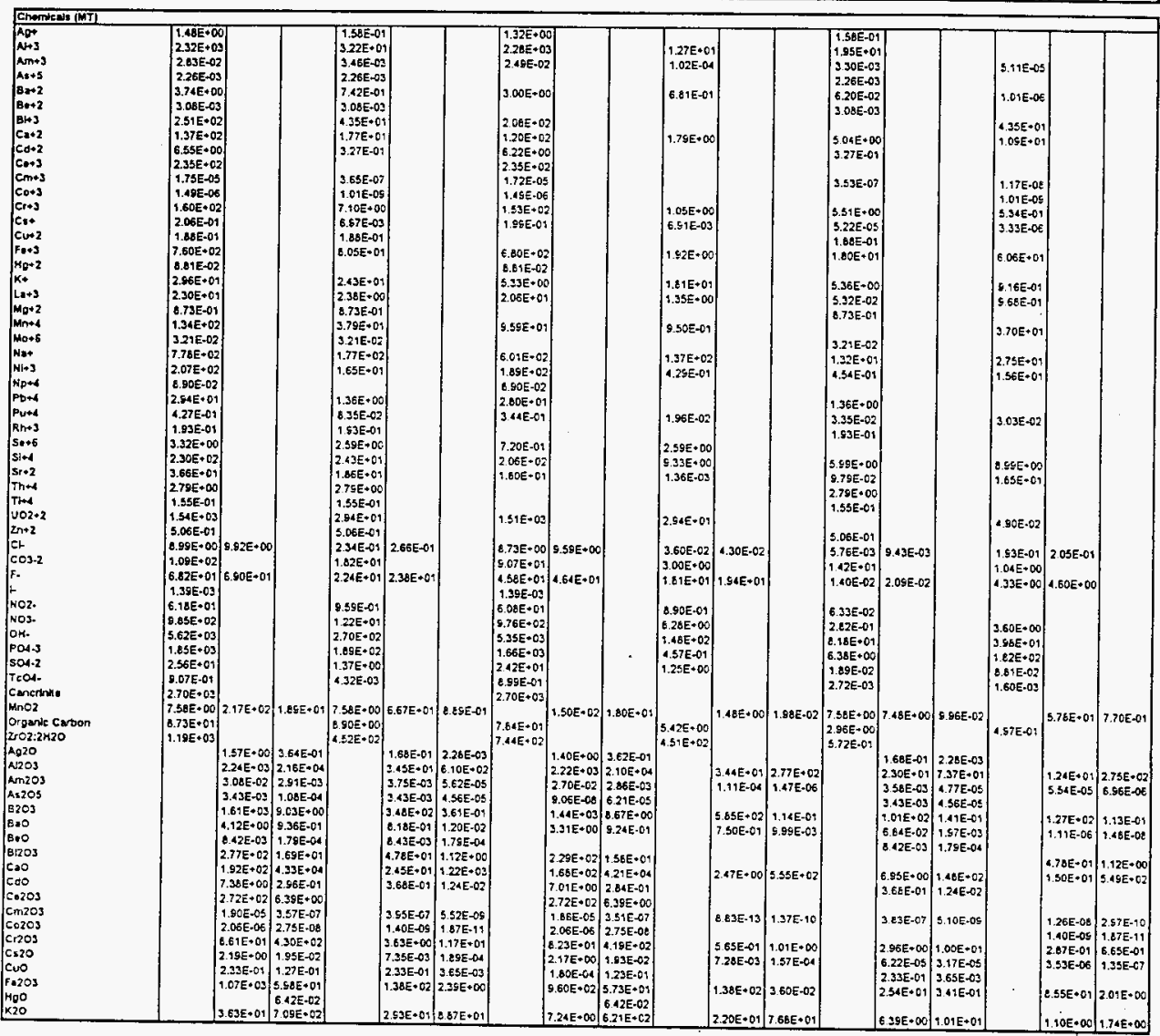
A-13
Page 3

11/10/95 
WHC-SD-WM-ES-386

Revision 0

Table 2. TRU Waste Volume Projections (Rev. 2) - Low Temperature Glass Formulation

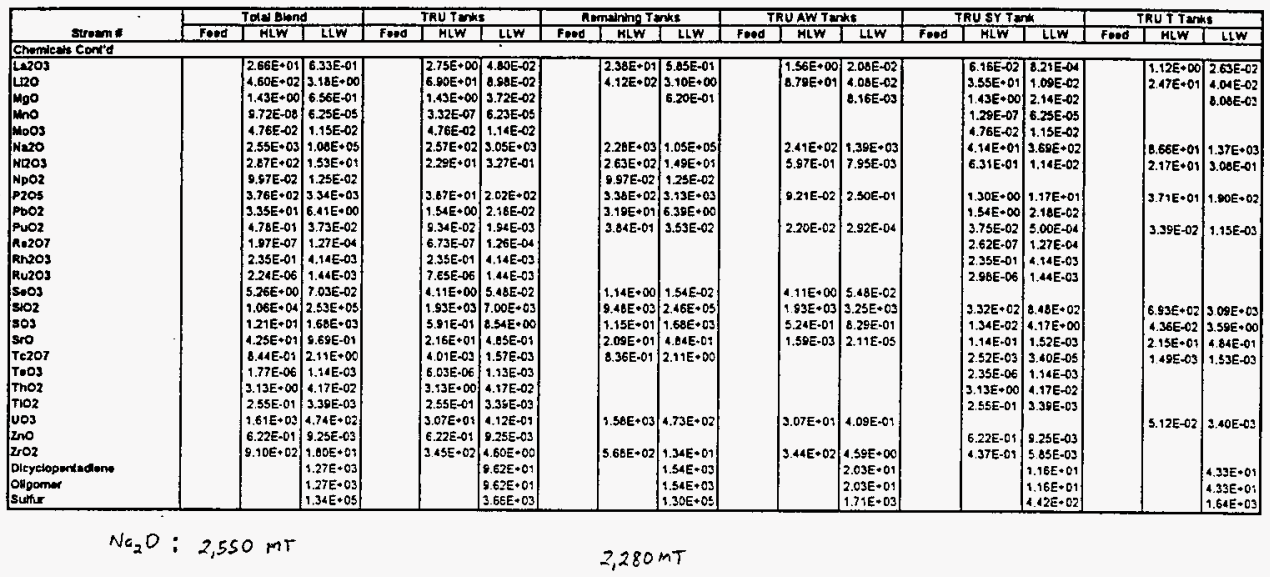


WHC-SD-WM-ES-386

Revision 0

Table 3. TRU Waste Volume Projections (Rev. 2) - Low Temperature Glass Formulation (Lower Limits Only)

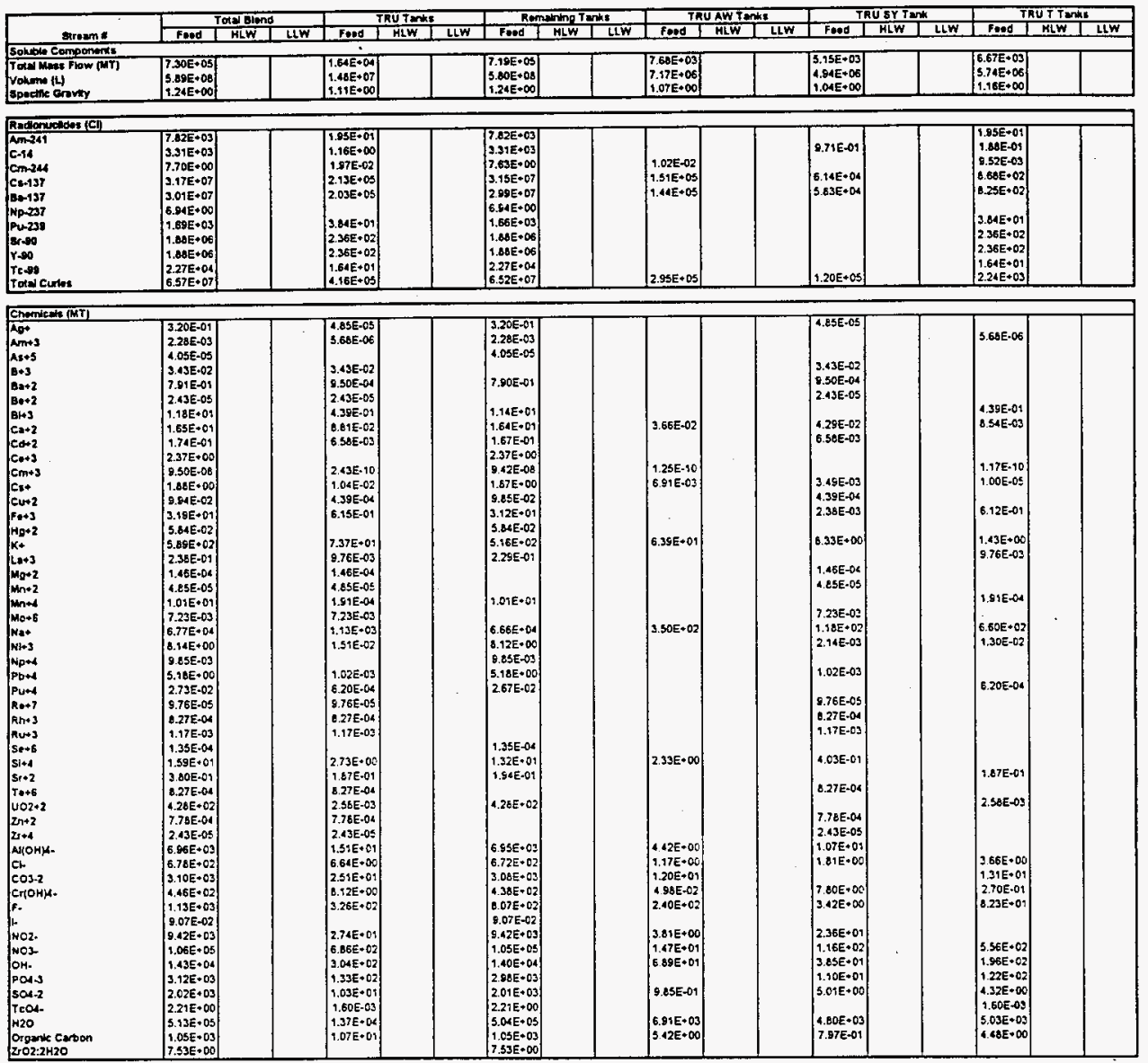


Table 3. TRU Waste Volume Projections (Rev, 2) - Low Temperature Glass Formulation (Lower Limits Only)

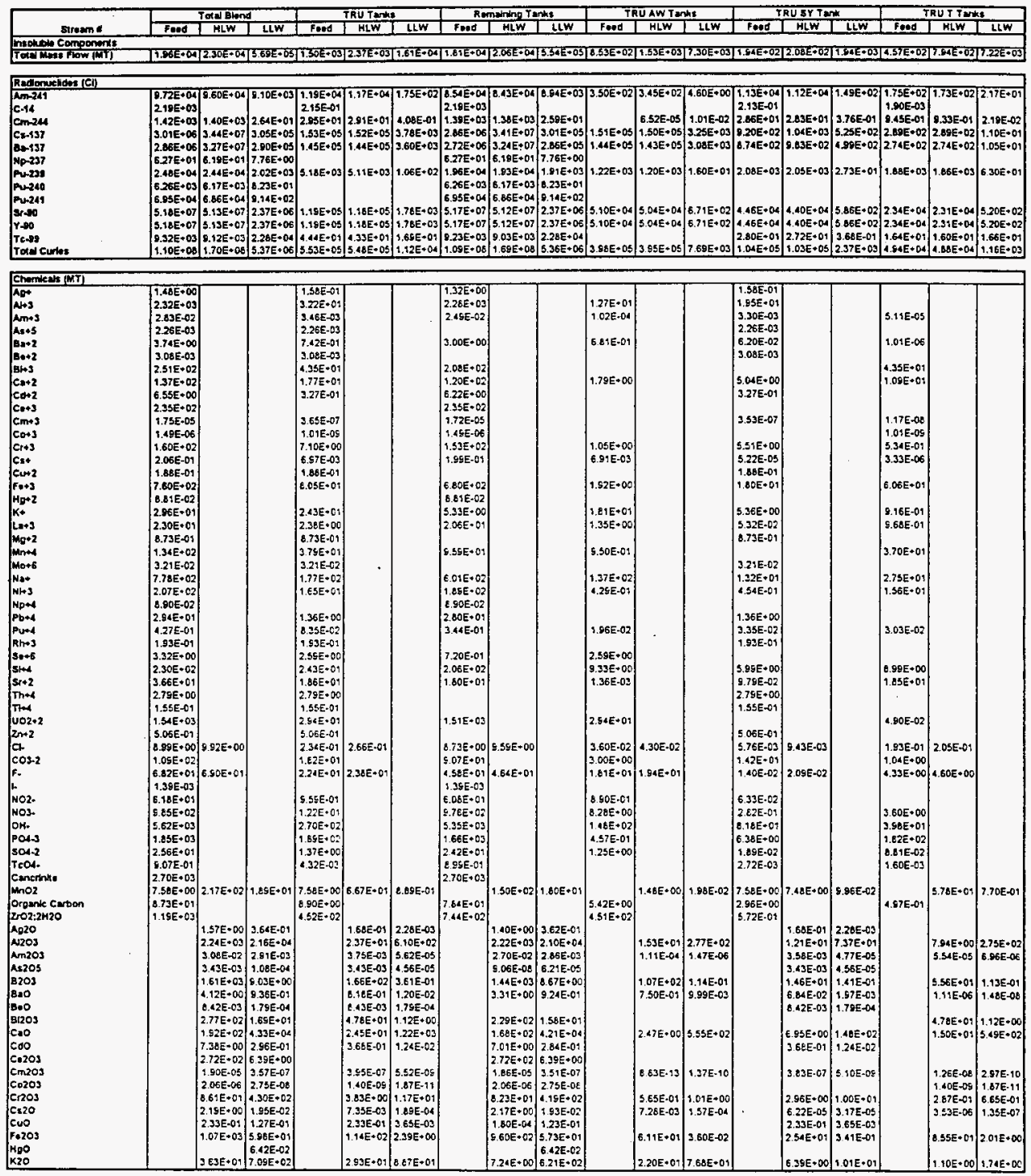


WHC-SD-WM-ES-386

Revision 0

Table 3. TRU Waste Volume Projections (Rev. 2) - Low Temperature Glass Formulation (Lower Limits Only)

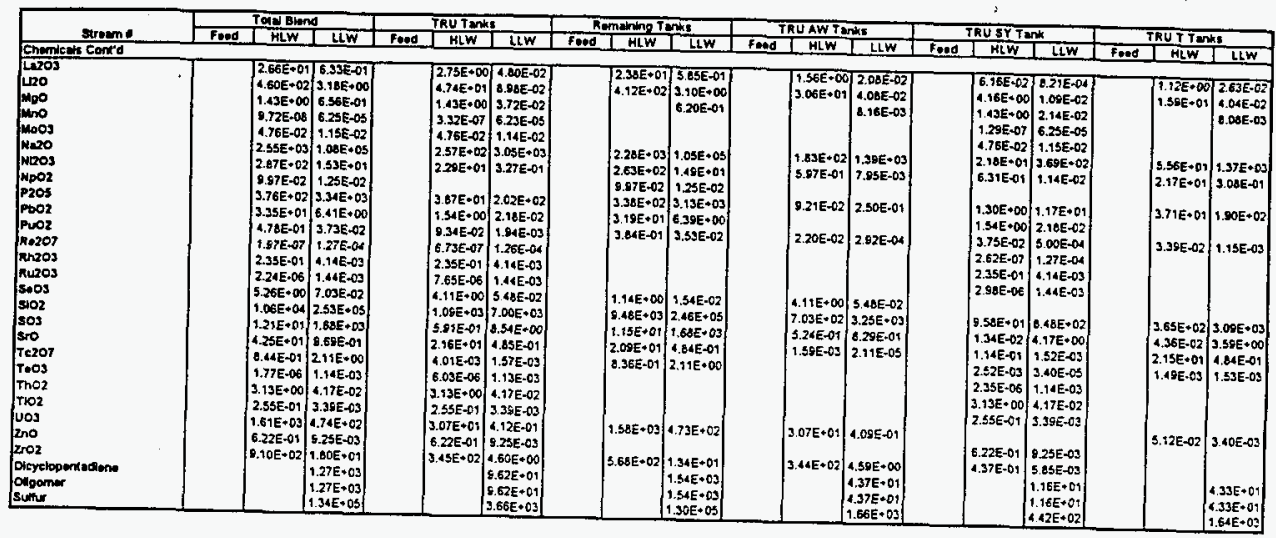

Page 7

$11 / 10 / 95$ 
WHC-SD-WM-ES-386

Revision 0

Table 2. TRU Waste Volume Projections (Rev. 2) - High Temperature Glass Formulation

\begin{tabular}{|c|c|c|c|c|c|c|c|c|c|c|c|c|c|c|c|c|c|c|}
\hline \multirow[b]{2}{*}{ strean: } & \multicolumn{3}{|c|}{ Total Bland } & \multicolumn{3}{|c|}{ TRU Tark: } & \multicolumn{3}{|c|}{ Romalning Tanks } & \multicolumn{3}{|c|}{ TRUAW TEnts: } & \multicolumn{3}{|c|}{ TRU SY T ind } & \multicolumn{3}{|c|}{ TRU Y Trikt } \\
\hline & Foed & HLW & HW & Fond & HLW & LLW & Food & $\mathrm{HLW}$ & Liw & Food & $H L W$ & LIW & Faed & MLW & ILW & Foed & HLW & LLW \\
\hline \multicolumn{19}{|l|}{ Solusin Compenomie } \\
\hline $\begin{array}{l}7 \text { otel hoss Flow (WT) } \\
\text { Vohume (L) } \\
\text { Spache Eraviny }\end{array}$ & \begin{tabular}{|l|}
$7.30 E+05$ \\
$5.69 E+08$ \\
$1.24 E+00$
\end{tabular} & & & $\begin{array}{l}1.64 E+0.4 \\
1.48 E+07 \\
1.11 E+\infty\end{array}$ & & & $\left|\begin{array}{l}7.19 E+05 \\
5.60 E+00 \\
1.24 E+00\end{array}\right|$ & & & $\mid \begin{array}{l}7.68 E+03 \\
7.37 E+06 \\
1.07 E+00\end{array}$ & & & $\left|\begin{array}{l}3.15 E+03 \\
4.94 E+06 \\
1.04 E+00\end{array}\right|$ & & & $\begin{array}{l}667 E \cdot 03 \\
5.74 E+06 \\
1.16 E+00\end{array}$ & & \\
\hline \multicolumn{19}{|l|}{ Radonuclides (C) } \\
\hline 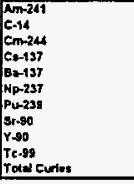 & \begin{tabular}{|l|}
$7.02 \mathrm{E}+03$ \\
$3.31 \mathrm{E}+03$ \\
$7.70 \mathrm{C}+00$ \\
$3.17 \mathrm{E}+07$ \\
$3.01 \mathrm{E}+07$ \\
$6.94 \mathrm{E}+00$ \\
$1.69 \mathrm{E}+03$ \\
$1.66 \mathrm{E}+06$ \\
$7.68 \mathrm{E}+06$ \\
$2.27 \mathrm{E}+04$ \\
$6.57 \mathrm{E}+07$
\end{tabular} & & & $\mid \begin{array}{l}1.95 \mathrm{E}+09 \\
1.16 \mathrm{E}+00 \\
1.97 \mathrm{E}-02 \\
2.13 \mathrm{E}+05 \\
2.03 \mathrm{E}+05 \\
3.64 \mathrm{E}+01 \\
2.36 \mathrm{E}+02 \\
2.36 \mathrm{E}+02 \\
1.54 \mathrm{E}+09 \\
4.16 \mathrm{E}+05\end{array}$ & & & $\left|\begin{array}{l}7.62 \mathrm{E}+03 \\
3.31 \mathrm{E}+03 \\
7 . \mathrm{E} 3 \mathrm{E}+00 \\
3.15 \mathrm{E}+07 \\
2.89 \mathrm{E}+07 \\
6.94 \mathrm{E}+06 \\
1.66 \mathrm{E}+03 \\
1.08 \mathrm{E}+06 \\
1.08 \mathrm{E}+06 \\
2.27 \mathrm{E}+04 \\
6.52 \mathrm{E}+07\end{array}\right|$ & & & $\left\{\begin{array}{l}1.02 E-02 \\
1.51 E+05 \\
1.44 E+05\end{array}\right.$ & & & $\begin{array}{l}9.71 E-01 \\
6.14 E+04 \\
5.83 E+04\end{array}$ & & & {$\left[\begin{array}{l}1.95 E+01 \\
1.36 E-01 \\
9.52 E-02 \\
0.60 E+02 \\
8.25 E+02 \\
3.84 E+01 \\
2.36 E+02 \\
2.36 E+02 \\
1.64 E+01 \\
2.24 E+0.3\end{array} \mid\right.$} & & \\
\hline \multirow{2}{*}{\multicolumn{19}{|c|}{$\begin{array}{l}\text { Chemileds }(\mathrm{Mr}) \\
\mathrm{Ag}^{+}\end{array}$}} \\
\hline & & & & & & & & & & & & & & & & & & \\
\hline$A n+3$ & $2.28 E-03$ & & & $5.68 E-06$ & & & $2.2 \varepsilon E-03$ & & & & & & & & & $\$$ 68E.05 & & \\
\hline$A=+5$ & $4.05 E-05$ & & & & & & 4.05E.05 & & & & & & & & & & & \\
\hline $\begin{array}{l}8+3 \\
82+2\end{array}$ & $\left|\begin{array}{r}3.43 E-02 \\
7.81 E-01\end{array}\right|$ & & & $\left|\begin{array}{c}3.43 E-02 \\
.50 E-0.4\end{array}\right|$ & & & tom & & & & & & $\begin{array}{l}3.43 E-02 \\
\text { S.SOE-04 }\end{array}$ & & & & & \\
\hline $\mathrm{B} e+2$ & $2.43 E-05$ & & & $2.43 E-05$ & & & $7.50 E-01$ & & & & & & $2.43 E-05 \mid$ & & & & & \\
\hline$B+3$ & $1.18 E \div 01$ & & & $1.39 E-01$ & & & $1.14 E+09$ & & & & & & & & & $1.39 \mathrm{E}-01$ & & \\
\hline $\cos 2$ & $1.65 E+01$ & & & 8.81E-02 & & & {$[1.64 E+01]$} & & & $3.56 \mathrm{E}-02$ & & & $4.29 E-02$ & & & $8.54 E-03$ & & \\
\hline $\mathrm{Co}+2$ & $3,74 \mathrm{E}-01$ & & & $6.58 E-03$ & & & 1.57E-01 & & & & & & $6.38 E-03$ & & & & & \\
\hline $\begin{array}{l}c_{n+3} \\
C_{m+2}\end{array}$ & $\left|\begin{array}{l}2.37 E+\infty \\
5.50 E-08\end{array}\right|$ & & & $2.45 E-10$ & & & \begin{tabular}{|l|}
$2.37 \mathrm{E}-00$ \\
$9.42 \mathrm{E}-08$
\end{tabular} & & & $1.25 \mathrm{E}-10$ & & & & & & & & \\
\hline $\begin{array}{l}C m+2 \\
c=+\end{array}$ & $\left|\begin{array}{c}5.50 E \cdot 08 \\
1.08 E \bullet 00\end{array}\right|$ & & & $1,04 E-0 ?$ & & & $\left|\begin{array}{c}9.42 \mathrm{E}-08 \\
1.27 \mathrm{E}+00\end{array}\right|$ & & & 6.91E-03 & & & $3,49 E-03$ & & & $\begin{array}{c}1.17 E-10 \\
1.00 E-05\end{array}$ & & \\
\hline$C u+2$ & $0.54 E-02$ & & & 1.39E-OA & & & $9.85 E-02$ & & & & & & A. .99E-04 & & & $7.000-63 \mid$ & & \\
\hline$F \bullet+3$ & $3.10 E+01$ & & & 6.75E-01 & & & $3.12 \dot{E}+01$ & & & & & & $2.38 E-03$ & & & 6.12E-01 & & \\
\hline $\mathrm{HO} O 2$ & $5.04 E+02$ & & & & & & $5.84 E-02$ & & & & & & & & & & & \\
\hline$k+$ & $5.85 E+02$ & & & $7.37 \mathrm{E}=01$ & & & $5.16 E \cdot 02$ & & & $6.39 E+01$ & & & $0.33 E \cdot 00$ & & & $1.43 E+00$ & & \\
\hline $\ln n+3$ & $2.38 E+01$ & & & $9.76 \mathrm{E}-03$ & & & $2.25 \mathrm{E}-0.1$ & & & & & & & & & $8.36 \mathrm{E}-03$ & & \\
\hline$m g+2$ & $1.46 \mathrm{E}-0.4$ & & & $1.46 \mathrm{E}-04$ & & & & & & & & & $1.46 \mathrm{E}-04$ & & & & & \\
\hline $\min +2$ & $4.85 \mathrm{E}-05$ & & & $4.85 E-05$ & & & & & & & & & $4.85 \mathrm{E}-05$ & & & & & \\
\hline Mn+d & $1.01 E=01$ & & & I.STE-0A & & & $2.0: E+01$ & & & & & & & & & $1.51 E-04$ & & \\
\hline $\operatorname{Mon} 6$ & $7.23 E-03$ & & & $7.23 E=02$ & & & & & & & & & $7.23 E-02$ & & & & & \\
\hline Nas & $6.77 \mathrm{E} \cdot 0.04$ & & & $|1 .+3 E+C 3|$ & & & $6.66 \mathrm{E}+04$ & & & $3.50 E+02$ & & & $1.16 E-02$ & & & $6.60 E+02 \mid$ & & \\
\hline $\mid \begin{array}{l}\mathrm{Ni}+3 \\
\mathrm{~Np}+4\end{array}$ & S.14E+00) & & & 1.51E-02 & & & $8.12 E-00$ & & & & & & 2.3 E- 03 & & & $\mid 1.30 E-02$ & & \\
\hline $\mid \begin{array}{l}N p+d \\
P b+4\end{array}$ & $\left|\begin{array}{l}8.85 E \cdot 03 \\
5.18 E+00\end{array}\right|$ & & & $1.02 \mathrm{E}-03$ & & & $\left|\begin{array}{c}5.25 E \cdot 03 \\
5.18 E \cdot 00\end{array}\right|$ & & & & & & & & & & & \\
\hline Pues & $2.73 E-02$ & & & $\left|\begin{array}{l}1.02 \mathrm{E}-03 \\
6.20 \mathrm{E}-04\end{array}\right|$ & & & $\left|\begin{array}{c}5.18 E \cdot 00 \\
2.67 E-02\end{array}\right|$ & & & & & & $1.02 \mathrm{E}-03$ & & & $\Leftrightarrow 20 \mathrm{E}-04$ & & \\
\hline Ro*7 & $9.76 \mathrm{E}-0 \mathrm{~S}$ & & & $9.76 E-0 S$ & & & & & & & & & $0.76 \mathrm{E}-0 \mathrm{~S}$ & & & & & \\
\hline Rnes & a.27E-04 & & & B.27E-04 & & & & & & & & & 8.27E-0. & & & & & \\
\hline Rut3 & $1,17 E-03$ & & & $\$ .17 \mathrm{E}-02$ & & & & & & & & & $1.17 \notin-03$ & & & & & \\
\hline $50+6$ & 1.35E-04 & & & & & & $1.35 \mathrm{E}+0 \mathrm{n}$ & & & & & & & & & & & \\
\hline $51+4$ & . $.59 E+0$. & & & $2,73 E+00$ & & & $1.32 \mathrm{E}+0$, & & & $|2.335 * 00|$ & & & 4.03E-01 & & & & & \\
\hline $3 r+2$ & $380 E-09$ & & & $1.07 \mathrm{E}+01$ & & & $1,54 E-02$ & & & & & & & & & $1.87 \mathrm{E}-01$ & & \\
\hline$T * * 6$ & $6.27 \mathrm{E}-04$ & & & e. $27 E-0<$ & & & & & & & & & $8.27 \mathrm{E}-0 \mathrm{~d}$ & & & & & \\
\hline $002+2$ & $4.28 E+02$ & & & $2.58 E-03$ & & & $4.28 \mathrm{E}+02$ & & & & & & & & & 2.SEE-D? & & \\
\hline $\mathrm{z} n+2$ & 7.7AE-0. & & & $7.7 B E-04$ & & & & & & & & & $7.70 E=04$ & & & & & \\
\hline$z+d$ & & & & $2,43 E-0 S$ & & & & & & $|1,42 E+00|$ & & & $\left|\begin{array}{c}2.13 E-05 \\
107 E-01\end{array}\right|$ & & & 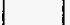 & & \\
\hline $\begin{array}{l}\text { AlOM, } \\
\text { C1- }\end{array}$ & $\left|\begin{array}{l}6.96 E+03 \\
6.78 E+02\end{array}\right|$ & & & $\left|\begin{array}{l}1.51 E+01 \\
6.64 E+00\end{array}\right|$ & & & $\left|\begin{array}{l}5.55 E+03 \\
6.72 \mathrm{E} \cdot 02\end{array}\right|$ & & & $1.17 \mathrm{E} \cdot 00$ & & & $\left|\begin{array}{l}1.07 E+01 \\
1 . \ell 1 E+00\end{array}\right|$ & & & $3.66 E+000$ & & \\
\hline $\cos -2$ & $0.10 \mathrm{E}+0 \mathrm{~s}$ & & & $2.51 E+01$ & & & 3.0EE+03 & & & $1,20 E * 01$ & & & & & & $1.39 E+01$ & & \\
\hline CrioH). & $4.465=02$ & & & $8,1 z E+\infty$ & & & $4,38 E * 02$ & & & $4.98 \mathrm{E}-02$ & & & $2.80 E+00 \mid$ & & & $2.70 \mathrm{~T}-01$ & & \\
\hline F. & $\begin{array}{l}1.13 E+09 \\
907 E-02\end{array}$ & & & $3.26 \mathrm{E} \div 02$ & & & $\begin{array}{l}8.07 E+02 \\
9.075-02\end{array}$ & & & $2.40 E+02$ & & & $|3.42 E+00|$ & & & $0.23 \mathrm{E} \cdot 01$ & & \\
\hline NO2- & $\left|\begin{array}{l}9.07 \mathrm{E}-02 \\
9.42 \mathrm{E}+03\end{array}\right|$ & & & $2.74 E+01$ & & & $\left|\begin{array}{l}9.07 E-02 \\
5.42 E+02\end{array}\right|$ & & & $2.81 E+00$ & & & $2.36 \mathrm{E} * 01$ & & & - & & \\
\hline NOS. & $1.05 E+05$ & & & $5.06 \mathrm{E}+02$ & & & $1,05 E * 05$ & & & $1.476 * 09$ & & & $1.96 \mathrm{E}-02 \mid$ & & & $\mid 5.56 \mathrm{E}+02$ & & \\
\hline $\mathrm{OH}$. & $1,43 E, 0.4$ & & & $300=02$ & & & $1.40 E+0<$ & & & 6.AEE +01 & & & $3.45 E+01$ & & & $1.96 \mathrm{E}+02$ & & \\
\hline POA-3 & $3.12 E \div 03$ & & & $1.33 E+02$ & & & $2.56 E \cdot 02$ & & & & & & $1.10 \mathrm{E}+01$ & & & $1,22 \mathrm{E}+02$ & & \\
\hline$\$ 04.2$ & $2.02 \mathrm{E}+03$ & & & $1.03 E+01$ & & & 2 ONE.09 & & & S.85E-01 & & & $5.01 E+00$ & & & $4.32 E+00$ & & \\
\hline Teas- & $2.21 E+\infty)$ & & & 1.EOE- 03 & & & $2.21 E+00$ & & & & & & & & & $1.60 \mathrm{E} \cdot 03$ & & \\
\hline $\begin{array}{l}\mathrm{H} 20 \\
\text { Oroudc Cerbon }\end{array}$ & 5.13E 05 & & & $\begin{array}{l}1.37 \mathrm{E}+04 \\
1.07 \mathrm{E} \cdot 01\end{array}$ & & & S.OAE+05 & & & $6.91 E \cdot 03$ & & & $4.80 E+0.3$ & & & $5.03 E+03$ & & \\
\hline $\begin{array}{l}\text { Organde Cerbon } \\
2 \text { 2ro2:2H2O }\end{array}$ & $\left|\begin{array}{l}1.05 \mathrm{E} E \cdot 03 \\
7.53 E \bullet 00\end{array}\right|$ & & & & & & $\left|\begin{array}{l}1.05 E+03 \\
7.53 E+00\end{array}\right|$ & & & $|5.42 E+\infty 0|$ & & & $7.57 \mathrm{E}-0 \mathrm{O}$ & & & $|4.48 E * 00|$ & & \\
\hline
\end{tabular}




\begin{tabular}{|c|c|c|c|c|c|c|c|c|c|c|c|c|c|c|c|c|c|c|}
\hline trom & \multicolumn{3}{|c|}{ Tous ono } & \multicolumn{3}{|c|}{ 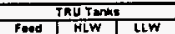 } & \multicolumn{3}{|c|}{ Romenning Tonst } & \multicolumn{3}{|c|}{ TRU AW Tank } & \multicolumn{3}{|c|}{ TRUSY T ank } & \multicolumn{3}{|c|}{ T T Tonks } \\
\hline & & & & & & & 1 & & & SEE & & & $30 \mathrm{de}$ & & & & & \\
\hline 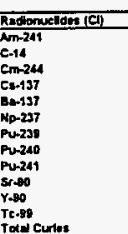 & 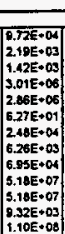 & 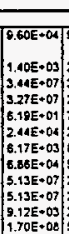 & 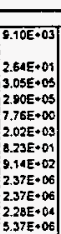 & $\begin{array}{l}1.19 E+01 \\
2.15 E-01 \\
2.95 E+09 \\
1.53 E+0 S \\
1.45 E+05 \\
5.18 E+03\end{array}$ & 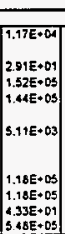 & $\begin{array}{l}1.73 E+02 \\
1.06 E-01 \\
3.78 E+03 \\
3.60 E+03 \\
1.06 E+02 \\
\\
1.78 E+03 \\
1.76 E+03 \\
1.69 E+01 \\
1.22 E+00\end{array}$ & 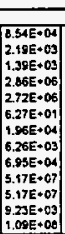 & 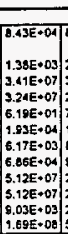 & 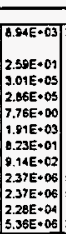 & $\left|\begin{array}{l}1.31 E+00 \\
1.44 E+05 \\
1.22 E+03\end{array}\right|$ & \begin{tabular}{|l|}
$3.45 E+02$ \\
$6.52 E-05$ \\
$1.50+05$ \\
$1.43 E+03$ \\
$1.20 E+03$ \\
\\
$5.04 E+04$ \\
$5.04 E+04$ \\
$3.95 E+05$ \\
\end{tabular} & $\begin{array}{l}1.01 E-02 \\
3.25 E+03 \\
3.00 E+03 \\
1.60 E+01\end{array}$ & \begin{tabular}{|l|}
$.13 E+04$ \\
$2.13 E-01$ \\
$2.86 E+01$ \\
$2.20 \mathrm{E}+02$ \\
$.74 \mathrm{E}-02$ \\
$2.08 \mathrm{E}=03$
\end{tabular} & \begin{tabular}{|}
$1.12 E \cdot 00$ \\
$2.83 E \cdot 09$ \\
$1.04 E \cdot 03$ \\
$0.03 E \cdot 02$ \\
$2.05 E+03$ \\
\\
$0.00 E \cdot 04$ \\
$6.40 E \cdot 04$ \\
$2.72 E \cdot 09$ \\
$1.03 E \cdot 05$
\end{tabular} & \begin{tabular}{|l}
$1.45 E+02$ \\
$3.76 E-01$ \\
$5.25 E-02$ \\
$6.99 E+02$ \\
$2.73 E-01$ \\
\\
$3.06 E+02$ \\
$5.86 E+02$ \\
$3.68 E-01$ \\
$2.37 E+03$
\end{tabular} & 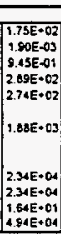 & 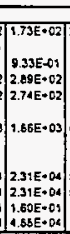 & 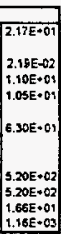 \\
\hline
\end{tabular}

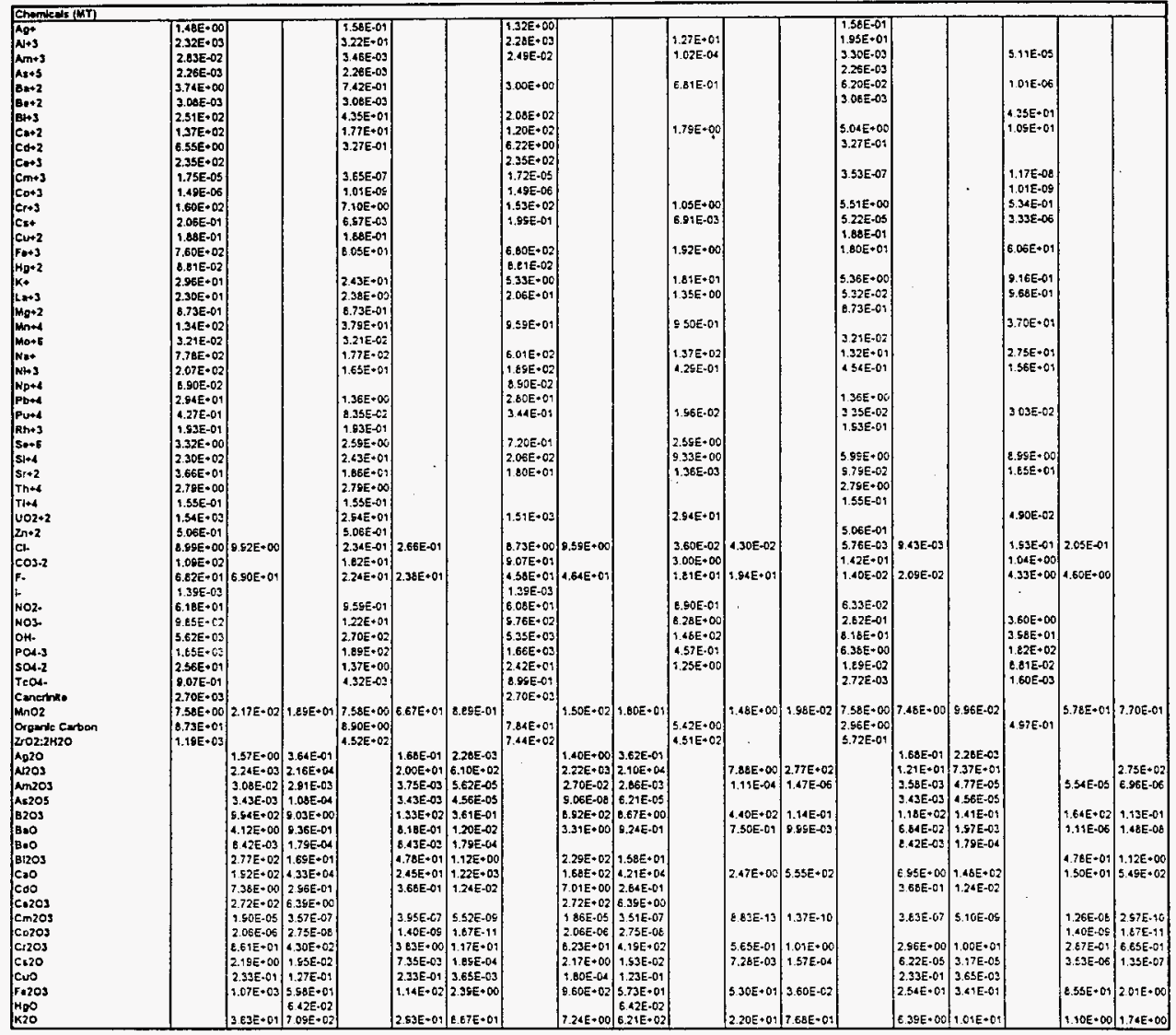




\section{WHC-SD-WM-ES-386}

Revision 0

Table 2. TRU Waste Volume Projections (Rev. 2) - High Temperature Glass Formulation

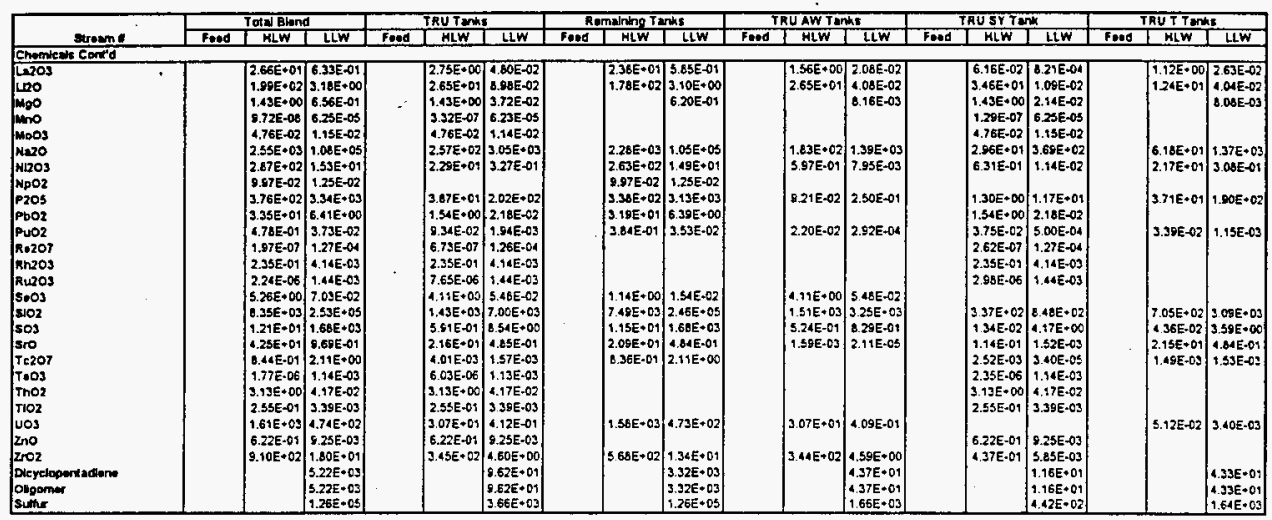




\section{Revision 0}

Table 3. TRU Waste Volume Projections (Rev. 2) - High Temperature Glass Formulation (Lower Limits Only)

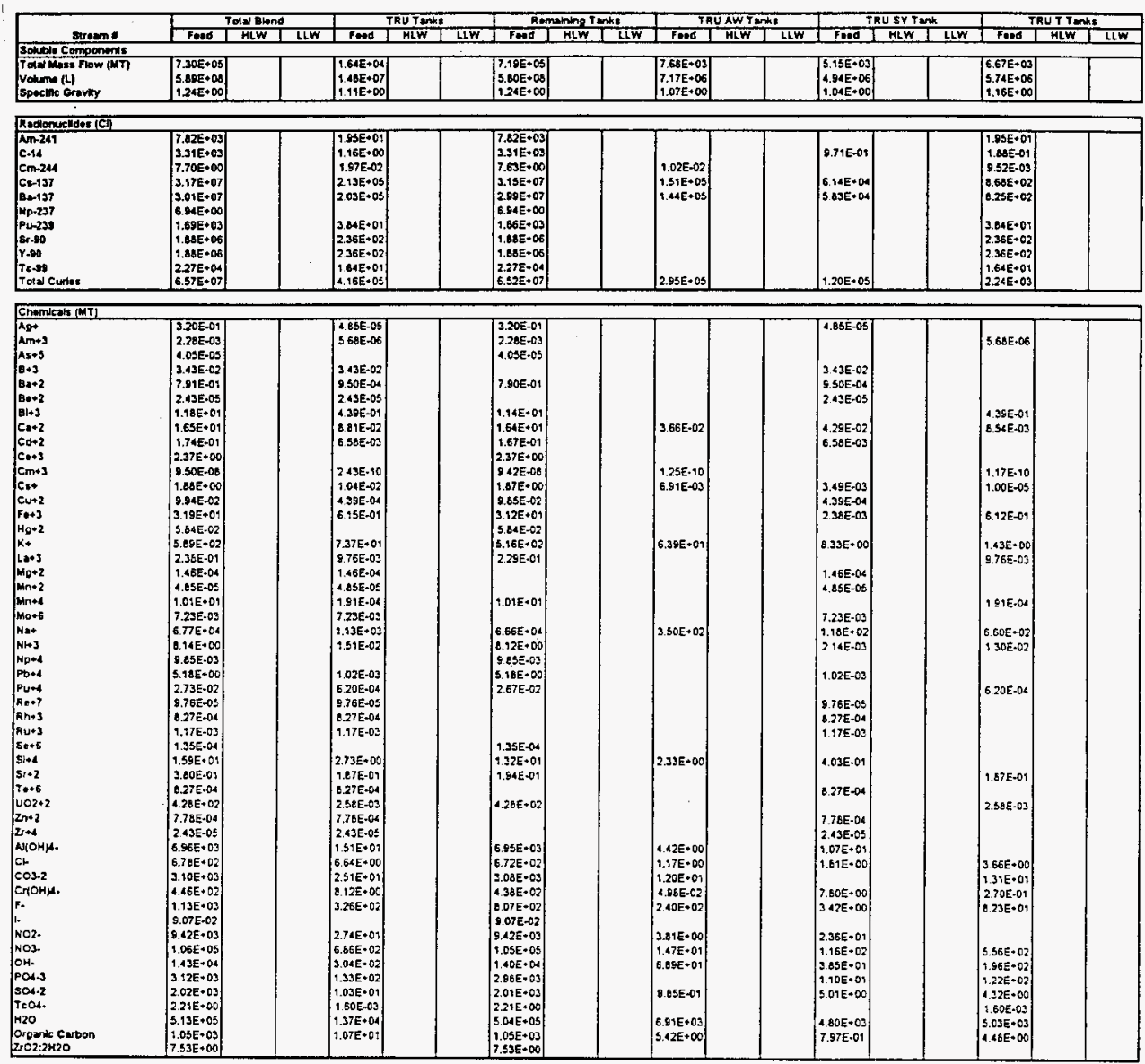




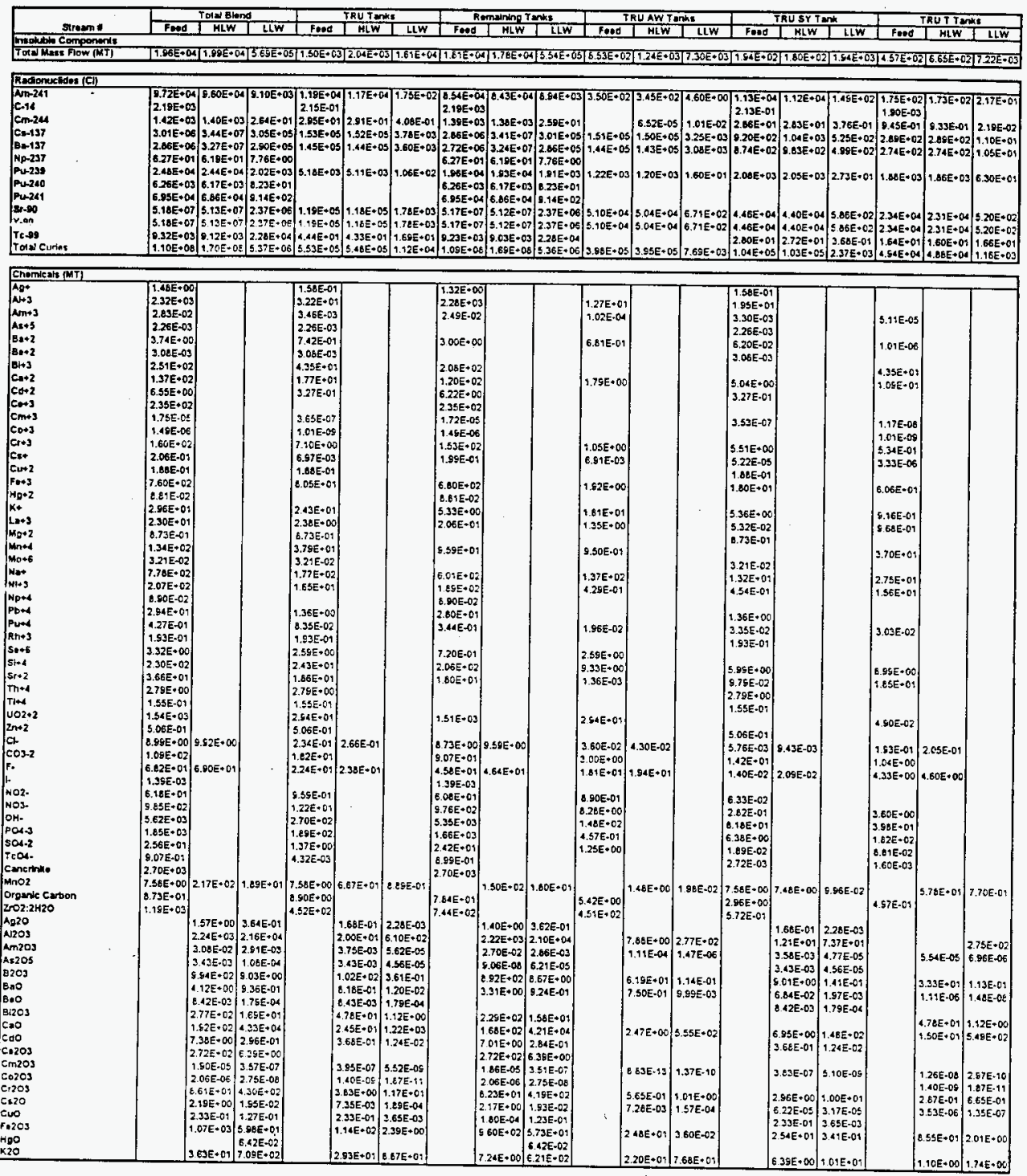


WHC-SD-WM-ES-386

Revision 0

Table 3. TRU Waste Volume Projections (Rev. 2) - High Temperature Glass Formulation (Lower Limits Only)

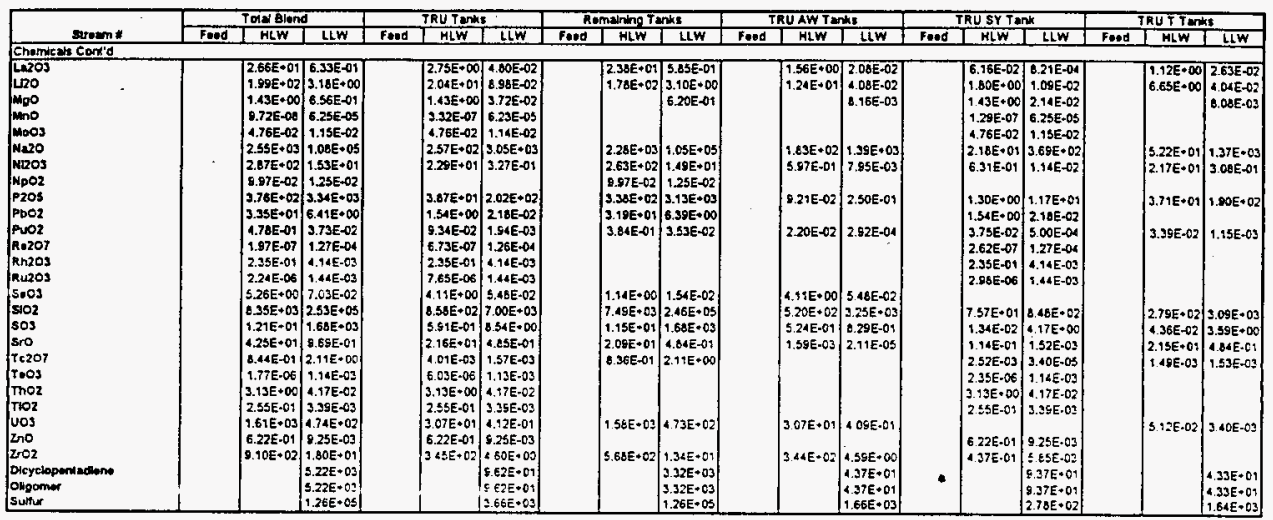


WHC-SD-WM-ES-386

Revision 0

This page intentionally left blank. 
WHC-SD-WM-ES-386

Revision 0

74A20-96-001

ATTACHMENT 2

TRU Waste Volume Projections (Revision 2) HLW Glass Formulation Output Data

\section{Low Temperature HWVP Glass Formulation \\ Low Temperature HWVP Glass Formulation (Lower Limits Only) \\ Low Temperature CVS Glass Composition \\ Low Temperature cvS Glass Composition (Lower Limits Only)}

Consisting of 25 pages, including cover page 
WHC-SD-WM-ES-386

Revision 0

This page intentionally left blank. 
WHC-SD-WM-ES-386

Revision 0

TRU Waste Volume Projections (Rev. 2) - Low Temperature HLW Glass Formulation

\begin{tabular}{|c|}
\hline $\begin{array}{r}\text { 9-Nov-95 } \\
09: 51: 20 \\
\text { 9 }\end{array}$ \\
\hline 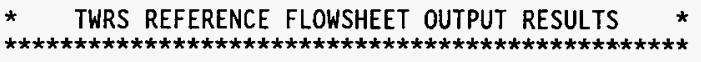 \\
\hline 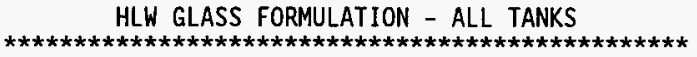 \\
\hline 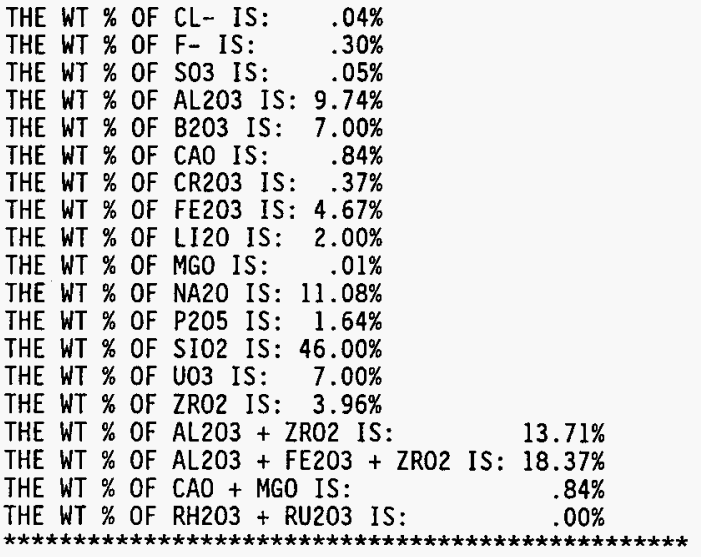 \\
\hline THE HL WASTE OXIDE LOADING IS: $51.3 \%$ \\
\hline 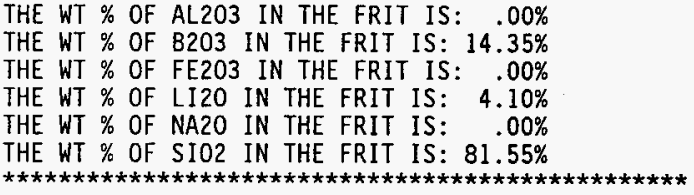 \\
\hline 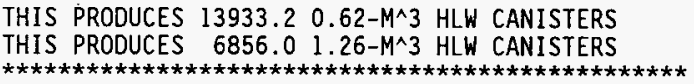 \\
\hline 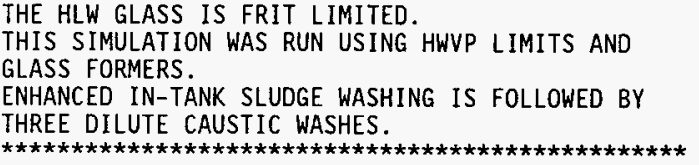 \\
\hline
\end{tabular}


TRU Waste Volume Projections (Rev. 2) - Low Temperature HLW Glass Formulation

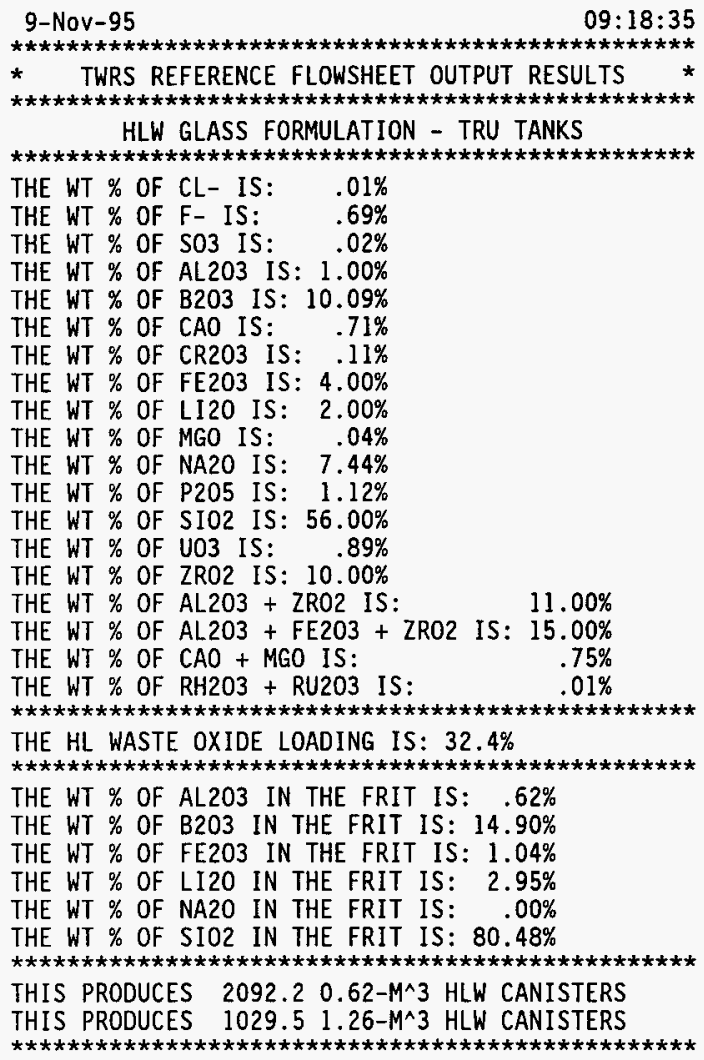

THE HLW GLASS IS ZRO2 LIMITED.

THIS SIMULATION WAS RUN USING HWVP LIMITS AND GLASS FORMERS.

ENHANCED IN-TANK SLUDGE WASHING IS FOLLOWED BY THREE DILUTE CAUSTIC WASHES. 
WHC-SD-WM-ES-386

Revision 0

TRU Waste Volume Projections (Rev. 2) - Low Temperature HLW Glass Formulation

9-Nov-95

$09: 59: 46$

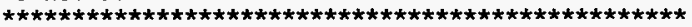

* TWRS REFERENCE FLOWSHEET OUTPUT RESULTS *

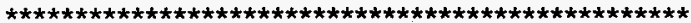

HLW GLASS FORMULATION - REMAINING TANKS

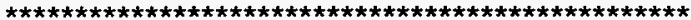

THE WT \% OF CL- IS: $\quad .05 \%$

THE WT \% OF F- IS: $.22 \%$

THE WT \% OF S03 IS: $.06 \%$

THE WT \% OF AL203 IS: $10.76 \%$

THE WT \% OF B203 IS: $7.00 \%$

THE WT \% OF CAO IS: $.82 \%$

THE WT \% OF CR203 IS: .40\%

THE WT \% OF FE203 IS: $4.66 \%$

THE WT \% OF LI20 IS: $2.00 \%$

THE WT \% OF MGO IS: $\quad .00 \%$

THE WT \% OF NA2O IS: $11.06 \%$

THE WT \% OF P205 IS: $1.64 \%$

THE WT \% OF SIO2 IS: $46.00 \%$

THE WT \% OF U03 IS: $7.67 \%$

THE WT \% OF ZRO2 IS: $2.76 \%$

THE WT \% OF AL2O3 + ZR02 IS: $13.51 \%$

THE WT \% OF AL203 + FE203 + ZRO2 IS: $18.17 \%$

THE WT \% OF CAO + MGO IS:

THE WT \% OF RH203 + RU203 IS: .00\%

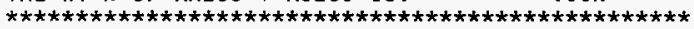

THE HL WASTE OXIDE LOADING IS: $51.8 \%$

*******************************************************

THE WT \% OF AL203 IN THE FRIT IS: $.00 \%$

THE WT \% OF B203 IN THE FRIT IS: $14.49 \%$

THE WT \% OF FE203 IN THE FRIT IS: .00\%

THE WT \% OF LI2O IN THE FRIT IS: $4.14 \%$

THE WT \% OF NA2O IN THE FRIT IS: $.00 \%$

THE WT \% OF SIO2 IN THE FRIT IS: $81.38 \%$

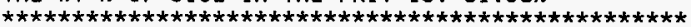

THIS PRODUCES $12497.40 .62-M \wedge 3$ HLW CANISTERS

THIS PRODUCES $6149.51 .26-M^{\wedge} 3$ HLW CANISTERS

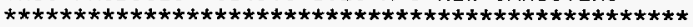

THE HLW GLASS IS FRIT LIMITED.

THIS SIMULATION WAS RUN USING HWVP LIMITS AND

GLASS FORMERS.

ENHANCED IN-TANK SLUDGE WASHING IS FOLLOWED BY THREE DILUTE CAUSTIC WASHES.

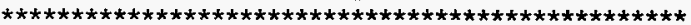


WHC-SD-WM-ES-386

Revision 0

TRU Waste Volume Projections (Rev. 2) - Low Temperature HLW Glass Formulation

9-Nov-95

$09: 20: 29$

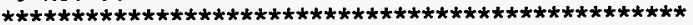

* TWRS REFERENCE FLOWSHEET OUTPUT RESULTS *

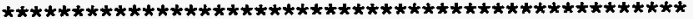
HLW GLASS FORMULATION - TRU AW TANKS

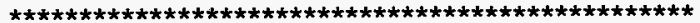

THE WT \% OF CL- IS: $\quad .00 \%$

THE WT \% OF F- IS: $\quad .56 \%$

THE WT \% OF SO3 IS: $.02 \%$

THE WT \% OF AL203 IS: $1.00 \%$

THE WT \% OF B203 IS: $17.00 \%$

THE WT \% OF CAO IS: $.07 \%$

THE WT \% OF CR203 IS: .02\%

THE WT \% OF FE203 IS: $4.00 \%$

THE WT \% OF LI20 IS: $2.55 \%$

THE WT \% OF MGO IS: $.00 \%$

THE WT \% OF NA2O IS: $7.00 \%$

THE WT \% OF P205 IS: $.00 \%$

THE WT \% OF SIO2 IS: $56.00 \%$

THE WT \% OF V03 IS: $.89 \%$

THE WT \% OF ZRO2 IS: $10.00 \%$

THE WT \% OF AL203 + ZR02 IS: $11.00 \%$

THE WT \% OF AL203 + FE203 + ZRO2 IS: $15.00 \%$

THE WT \% OF CAO + MGO IS: $\quad .07 \%$

THE WT \% OF RH203 + RU203 IS: .00\%

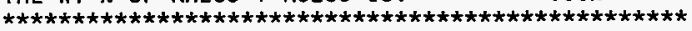

THE HL WASTE OXIDE LOADING IS: $18.8 \%$

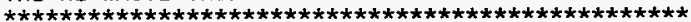

THE WT \% OF AL203 IN THE FRIT IS: .95\%

THE WT \% OF B203 IN THE FRIT IS: $20.89 \%$

THE WT \% OF FE203 IN THE FRIT IS: $4.82 \%$

THE WT \% OF LI2O IN THE FRIT IS: $3.14 \%$

THE WT \% OF NA2O IN THE FRIT IS: $2.08 \%$

THE WT \% OF SI02 IN THE FRIT IS: $68.12 \%$

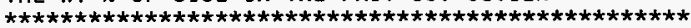

THIS PRODUCES $2088.2 \quad 0.62-M^{\wedge} 3$ HLW CANISTERS

THIS PRODUCES $1027.51 .26-M^{\wedge} 3$ HLW CANISTERS

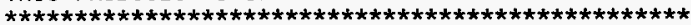

THE HLW GLASS IS ZRO2 LIMITED.

THIS SIMULATION WAS RUN USING HWVP LIMITS AND

GLASS FORMERS.

ENHANCED IN-TANK SLUDGE WASHING IS FOLLOWED BY THREE DILUTE CAUSTIC WASHES.

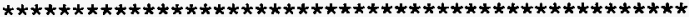


TRU Waste Volume Projections (Rev. 2) - Low Temperature HLW Glass Formulation

\begin{tabular}{|c|}
\hline 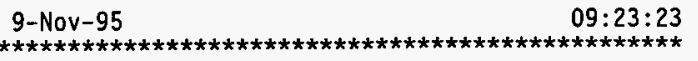 \\
\hline * TWRS REFERENCE FLOWSHEET OUTPUT RESULTS * \\
\hline 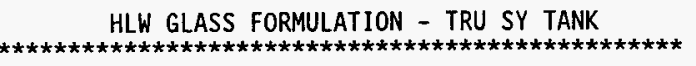 \\
\hline 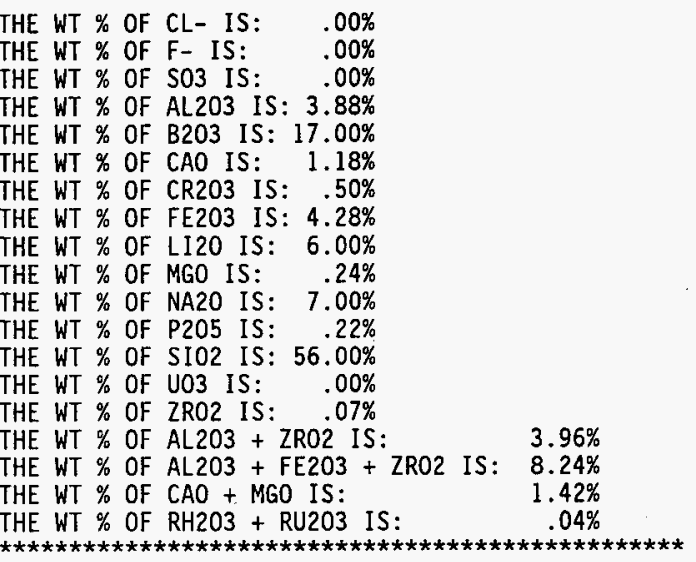 \\
\hline THE HL WASTE OXIDE LOADING IS: $18.1 \%$ \\
\hline 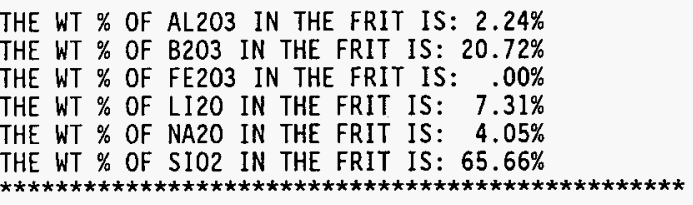 \\
\hline 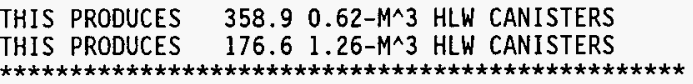 \\
\hline $\begin{array}{l}\text { THE HLW GLASS IS CR203 LIMITED. } \\
\text { THIS SIMULATION WAS RUN USING HWVP LIMITS AND } \\
\text { GLASS FORMERS. } \\
\text { ENHANCED IN-TANK SLUDGE WASHING IS FOLLOWED BY } \\
\text { THREE DILUTE CAUSTIC WASHES. }\end{array}$ \\
\hline
\end{tabular}


TRU Waste Volume Projections (Rev. 2) - Low Temperature HLW Glass Formulation

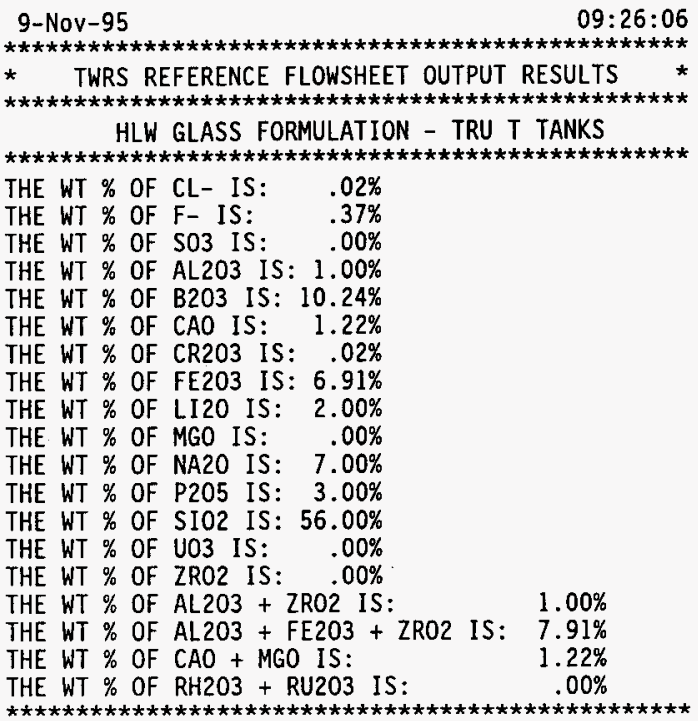

THE HL WASTE OXIDE LOADING IS: $29.7 \%$

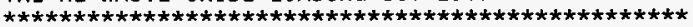

THE WT \% OF AL203 IN THE FRIT IS: $1.42 \%$

THE WT \% OF B203 IN THE FRIT IS: $14.53 \%$

THE WT \% OF FE203 IN THE FRIT IS: $.00 \%$

THE WT \% OF LI20 IN THE FRIT IS: $\cdot 2.84 \%$

THE WT \% OF NA2O IN THE FRIT IS: $3.95 \%$

THE WT \% OF SIO2 IN THE FRIT IS: $77.27 \%$

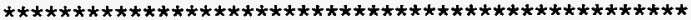

THIS PRODUCES 749.8 $0.62-M^{\wedge} 3$ HLW CANISTERS

THIS PRODUCES $368.91 .26-M^{\wedge} 3$ HLW CANISTERS

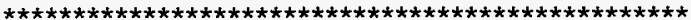

THE HLW GLASS IS P205 LIMITED.

THIS SIMULATION WAS RUN USING HWVP LIMITS AND GLASS FORMERS.

ENHANCED IN-TANK SLUDGE WASHING IS FOLLOWED BY THREE DILUTE CAUSTIC WASHES.

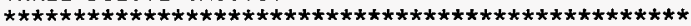


WHC-SD-WM-ES-386

Revision 0

TRU Waste Volume Projections (Rev. 2) - Low Temperature HLW Glass Formulation (Lower Limits Only)

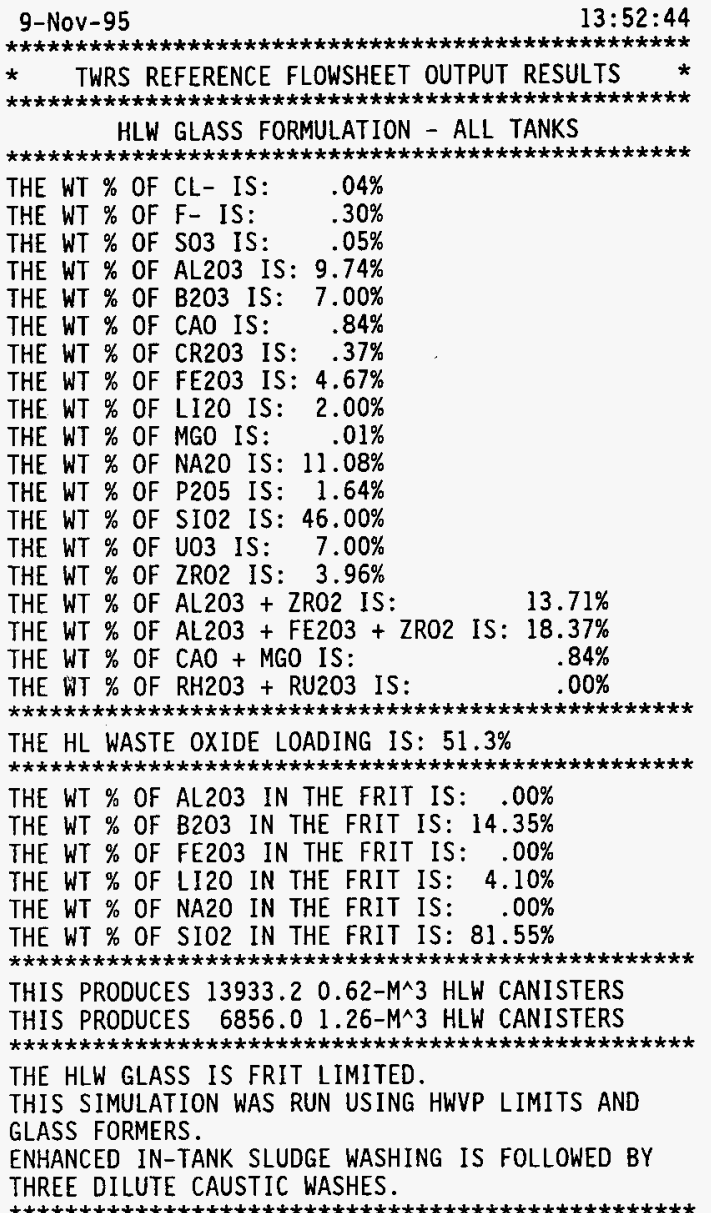


WHC-SD-WM-ES-386

Revision 0

TRU Waste Volume Projections (Rev. 2) - Low Temperature HLW Glass formulation (Lower Limits Only)

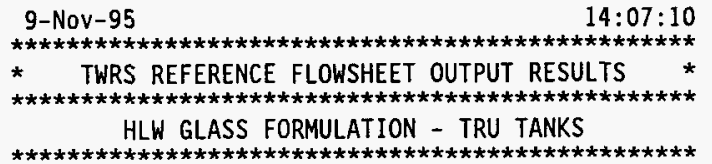

THE WT \% OF CL- IS: $.01 \%$

THE WT \% OF F- IS: $1.01 \%$

THE WT \% OF S03 IS: $.02 \%$

THE WT \% OF AL203 IS: $1.00 \%$

THE WT \% OF B203 IS: $7.00 \%$

THE WT \% OF CAO IS: $1.03 \%$

THE WT \% OF CR203 IS: $.16 \%$

THE WT \% OF FE203 IS: $4.80 \%$

THE WT \% OF LI20 IS: $2.00 \%$

THE WT \% OF MGO IS: $.06 \%$

THE WT \% OF NA20 IS: $10.84 \%$

THE WT \% OF P205 IS: $1.63 \%$

THE WT \% OF SI02 IS: $46.00 \%$

THE WT \% OF U03 IS: $1.30 \%$

THE WT \% OF ZRO2 IS: $14.57 \%$

THE WT \% OF AL203 + ZR02 IS: $15.57 \%$

THE WT \% OF AL203 + FE203 + ZR02 IS: $20.37 \%$

THE WT \% OF CAO + MGO IS: $1.09 \%$

THE WT \% OF RH203 + RU203 IS: .01\%

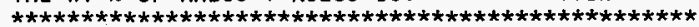

THE HL WASTE OXIDE LOADING IS: $47.1 \%$

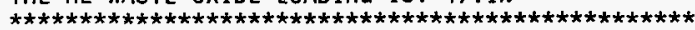

THE WT \% OF AL203 IN THE FRIT IS: .29\%

THE WT \% OF B203 IN THE FRIT IS: $13.21 \%$

THE WT \% OF FE203 IN THE FRIT IS: $.00 \%$

THE WT \% OF LI2O IN THE FRIT IS: $3.77 \%$

THE WT $\%$ OF NA2O IN THE FRIT IS: $.00 \%$

THE WT $\%$ OF SIO2 IN THE FRIT IS: $82.72 \%$

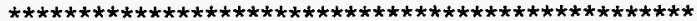

THIS PRODUCES 1435.9 0.62-M^3 HLW CANISTERS

THIS PRODUCES $706.61 .26-M^{\wedge} 3$ HLW CANISTERS

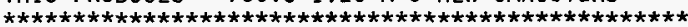

THE HLW GLASS IS FRIT LIMITED.

THIS SIMULATION WAS RUN USING HWVP LIMITS AND

GLASS FORMERS.

ENHANCED IN-TANK SLUDGE WASHING IS FOLLOWED BY THREE DILUTE CAUSTIC WASHES.

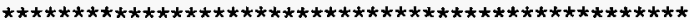


WHC-SD-WM-ES-386

Revision 0

TRU Waste Volume Projections (Rev. 2) - Low Temperature HLW Glass Formulation (Lower Limits Only)

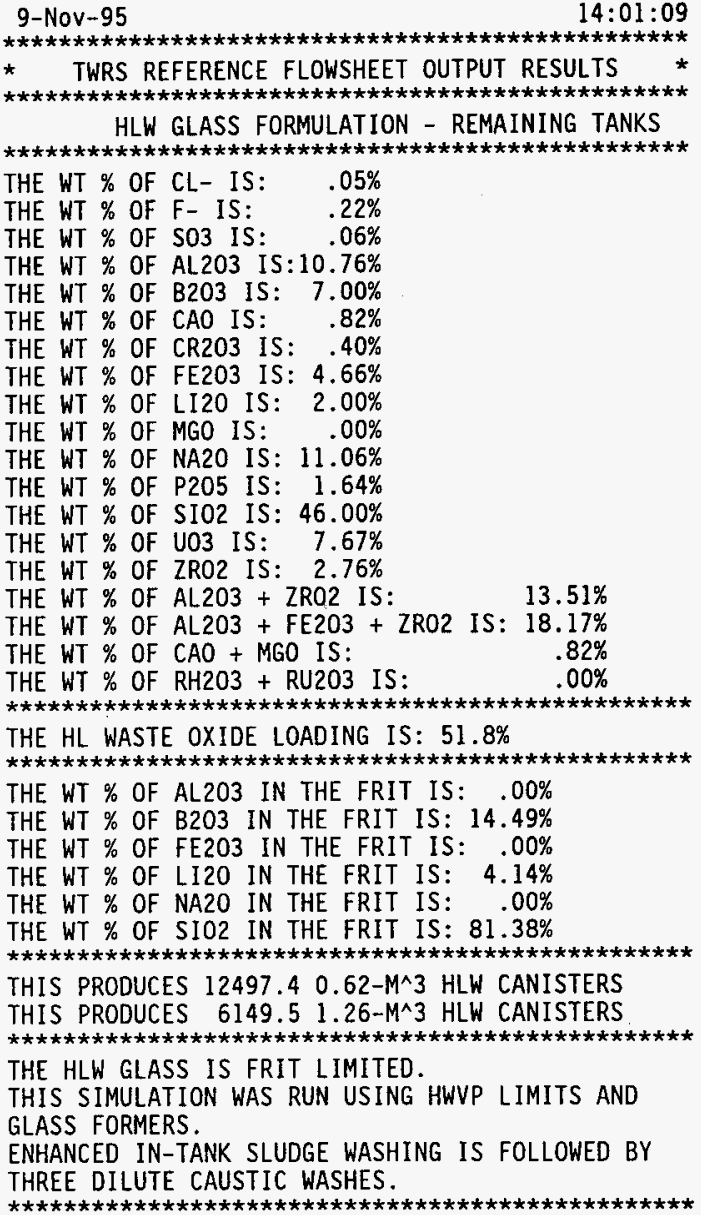


TRU Waste Volume Projections (Rev. 2) - Low Temperature HLW Glass Formulation (Lower Limits Only)

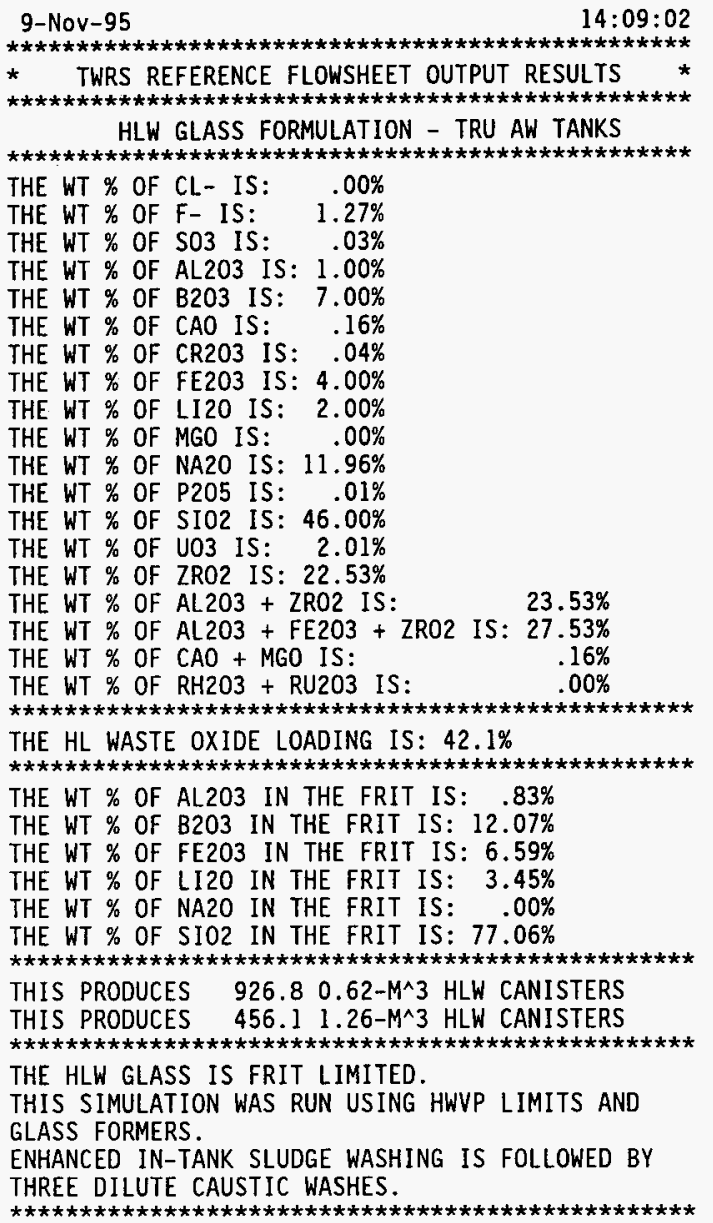


WHC-SD-WM-ES-386

Revision 0

TRU Waste Volume Projections (Rev. 2) - Low Temperature HLW G7ass Formulation (Lower Limits Only)

9-Nov-95

$14: 11: 46$

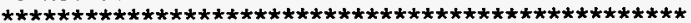

* TWRS REFERENCE FLOWSHEET OUTPUT RESULTS

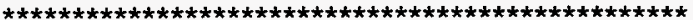
HLW GLASS FORMULATION - TRU SY TANK

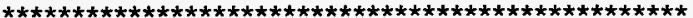

THE WT \% OF CL- IS: $\quad .00 \%$

THE WT \% OF F- IS: $.01 \%$

THE WT \% OF SO3 IS: $.01 \%$

THE WT \% OF AL203 IS: $5.80 \%$

THE WT \% OF B203 IS: $7.00 \%$

THE WT \% OF CAO IS: $3.34 \%$

THE WT \% OF CR203 IS: $1.42 \%$

THE WT \% OF FE203 IS: $12.18 \%$

THE WT \% OF LI20 IS: $2.00 \%$

THE WT \% OF MGO IS: $.69 \%$

THE WT \% OF NA2O IS: $10.44 \%$

THE WT \% OF P205 IS: $.62 \%$

THE WT \% OF SIO2 IS: $46.00 \%$

THE WT \% OF U03 IS: $.00 \%$

THE WT \% OF ZRO2 IS: .21\%

THE WT \% OF AL203 + ZRO2 IS: $6.01 \%$

THE WT \% OF AL203 + FE203 + ZRO2 IS: $18.19 \%$

THE WT \% OF CAO + MGO IS: $\quad 4.03 \%$

THE WT \% OF RH203 + RU203 IS: .11\%

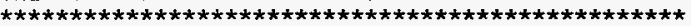

THE HL WASTE OXIDE LOADING IS: $51.2 \%$

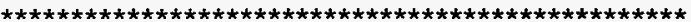

THE WT \% OF AL203 IN THE FRIT IS: .00\%

THE WT \% OF B203. IN THE FRIT IS: $14.31 \%$

THE WT \% OF FE203 IN THE FRIT IS: $.00 \%$

THE WT \% OF LI20 IN THE FRIT IS: $4.09 \%$

THE WT \% OF NA20 IN THE FRIT IS: $.00 \%$

THE WT \% OF SI02 IN THE FRIT IS: $81.61 \%$

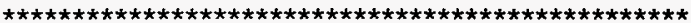

THIS PRODUCES $126.3 \quad 0.62-M^{\wedge} 3$ HLW CANISTERS

THIS PRODUCES $62.11 .26-M^{\wedge} 3$ HLW CANISTERS

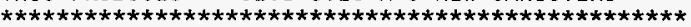

THE HLW GLASS IS FRIT LIMITED.

THIS SIMULATION WAS RUN USING HWVP LIMITS AND

GLASS FORMERS.

ENHANCED IN-TANK SLUDGE WASHING IS FOLLOWED BY

THREE DILUTE CAUSTIC WASHES.

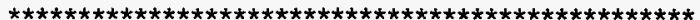


WHC-SD-WM-ES-386

Revision 0

TRU Waste Volume Projections (Rev. 2) - Low Temperature HLW Glass Formulation (Lower Limits Only)

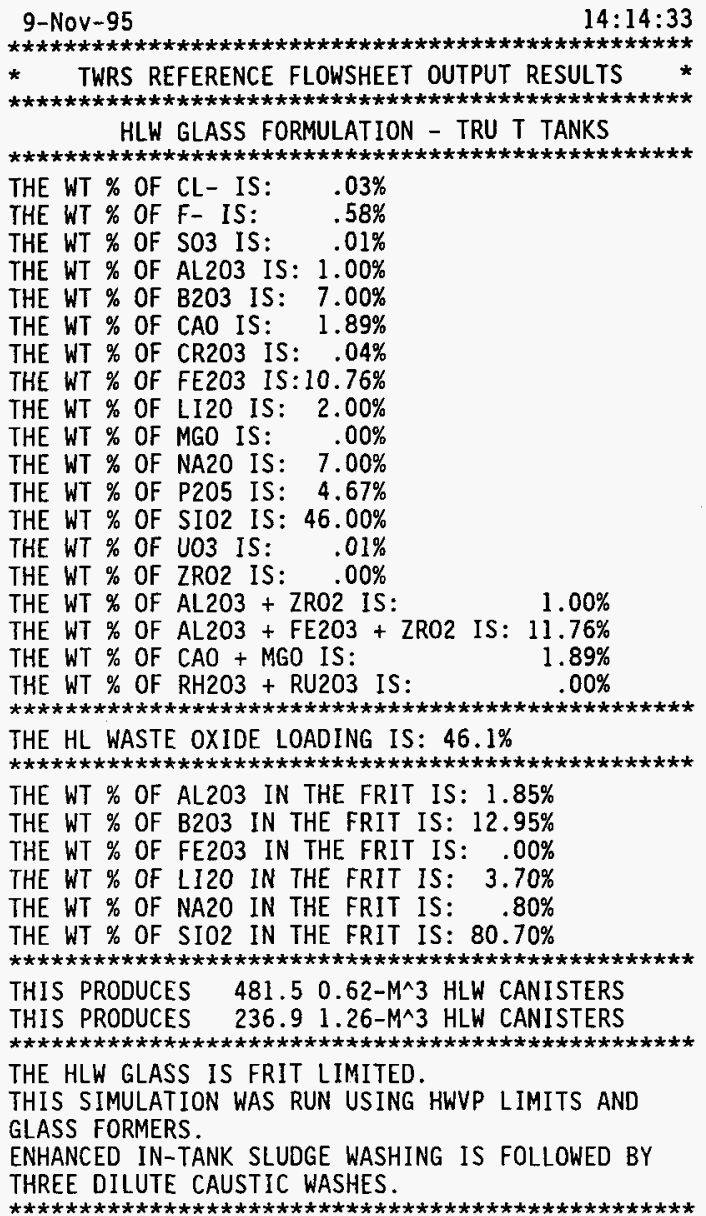


TRU Waste Volume Projections (Rev. 2) - High Temperature HLW Glass Formulation

\begin{tabular}{|c|}
\hline 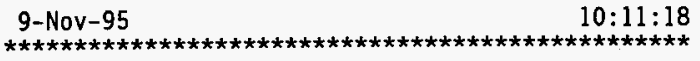 \\
\hline 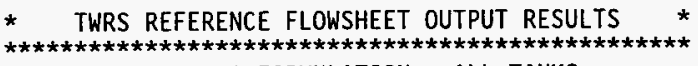 \\
\hline 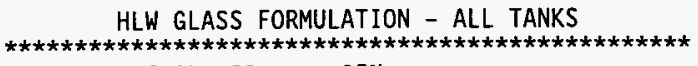 \\
\hline 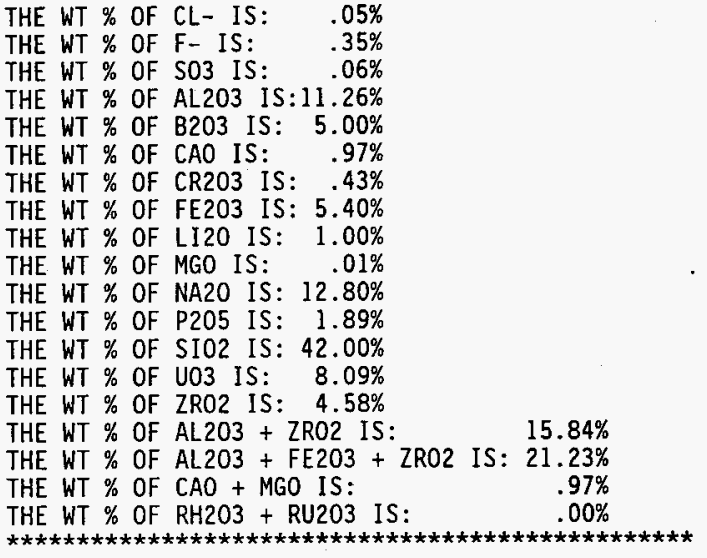 \\
\hline THE HI WASTE OXIDE LOADING IS: $59.3 \%$ \\
\hline 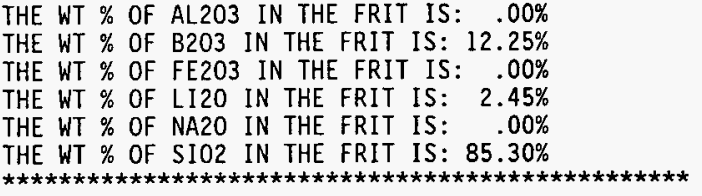 \\
\hline 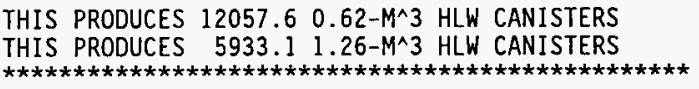 \\
\hline $\begin{array}{l}\text { THE HLW GLASS IS FRIT LIMITED. } \\
\text { THIS SIMULATION WAS RUN USING CVS LIMITS AND } \\
\text { GLASS FORMERS. } \\
\text { ENHANCED IN-TANK SLUDGE WASHING IS FOLLOWED BY } \\
\text { THREE DILUTE CAUSTIC WASHES. }\end{array}$ \\
\hline
\end{tabular}


WHC-SD-WM-ES-386

Revision 0

TRU Waste Volume Projections (Rev. 2) - High Temperature HLW Glass Formulation

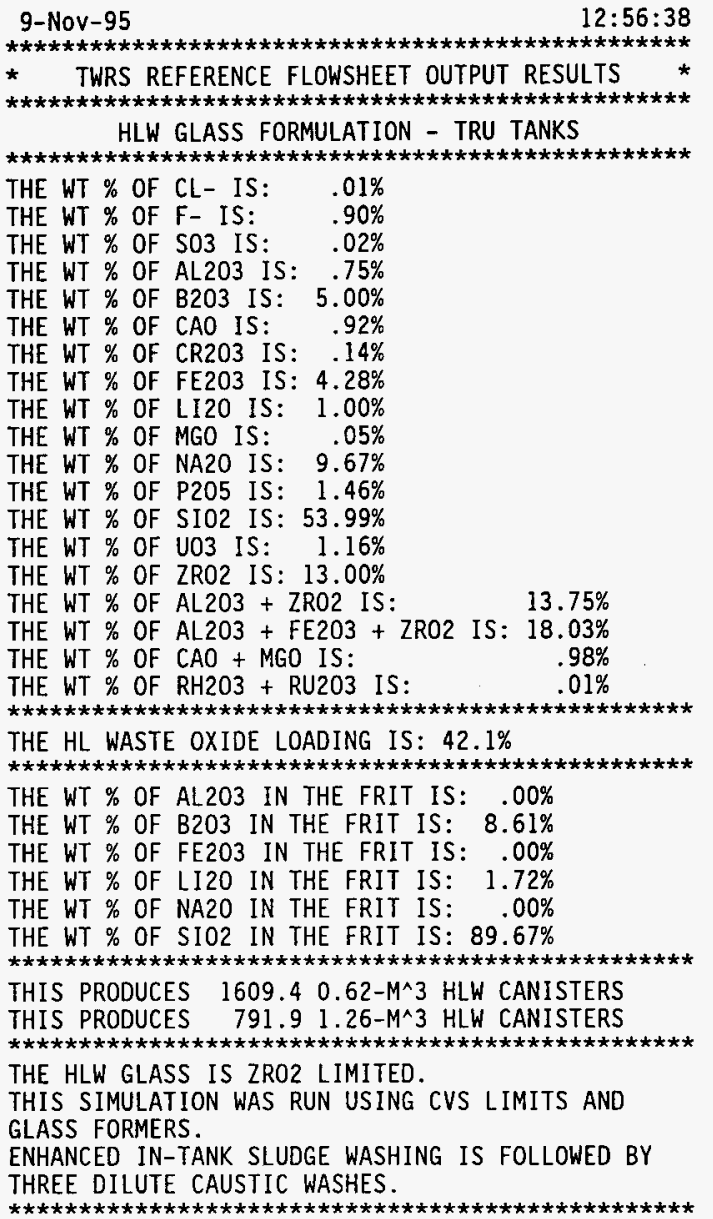


WHC-SD-WM-ES-386

Revision 0

TRU Waste Volume Projections (Rev. 2) - High Temperature HLW Glass Formulation

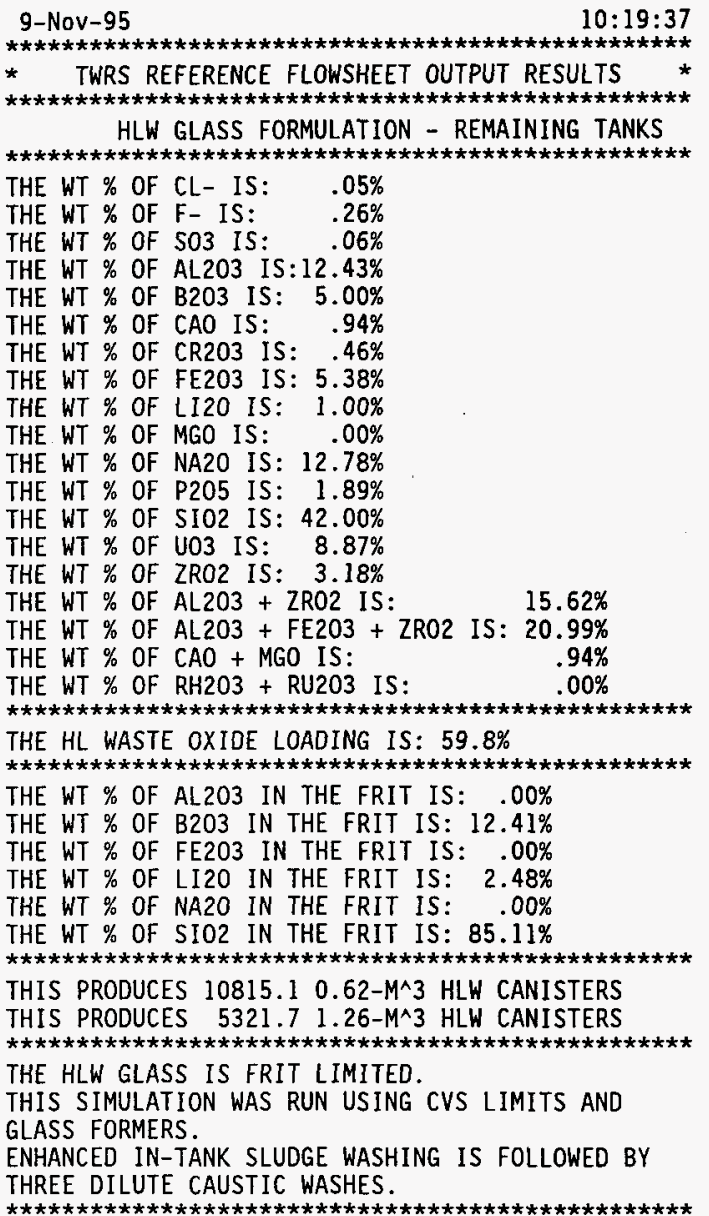


WHC-SD-WM-ES-386

Revision 0

TRU Waste Volume Projections (Rev. 2) - High Temperature HLW Glass Formulation

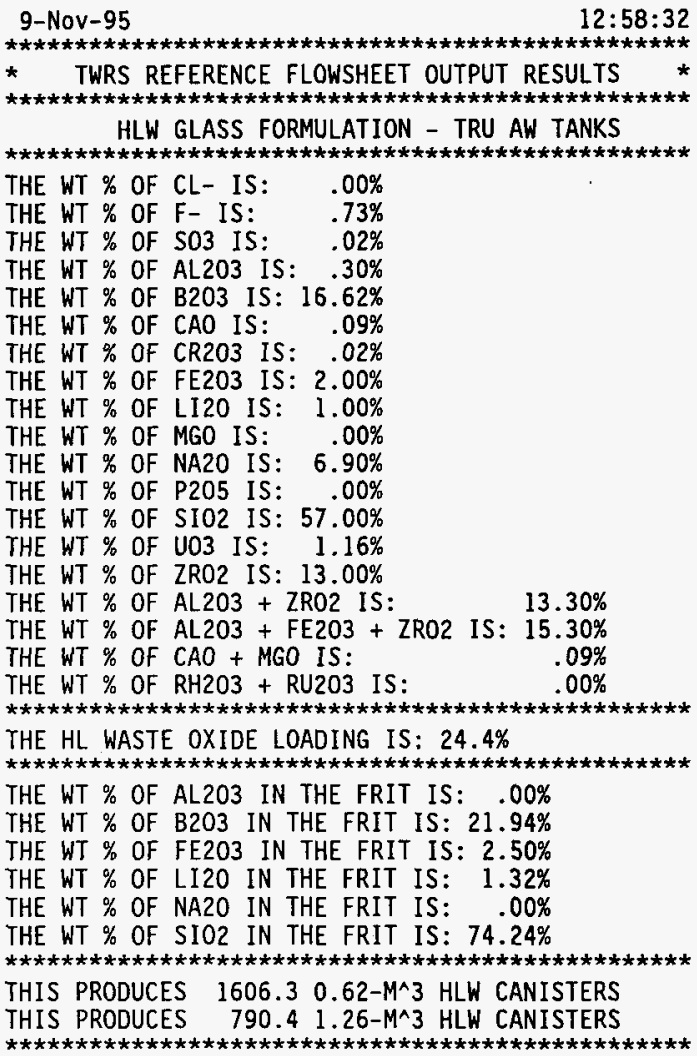

THE HLW GLASS IS ZRO2 LIMITED.

THIS SIMULATION WAS RUN USING CVS LIMITS AND

GLASS FORMERS.

ENHANCED IN-TANK SLUDGE WASHING IS FOLLOWED BY THREE DILUTE CAUSTIC WASHES. 
WHC-SD-WM-ES-386

Revision 0

TRU Waste Volume Projections (Rev. 2) - High Temperature HLW Glass Formulation

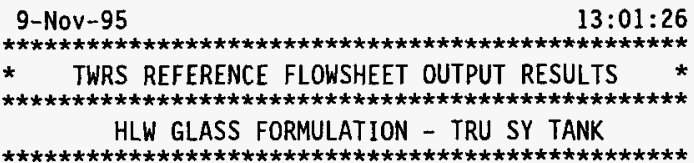

THE WT \% OF CL- IS: $\quad .00 \%$

THE WT \% OF F- IS: $\quad .00 \%$

THE WT \% OF S03 IS: $.00 \%$

THE WT \% OF AL203 IS: $2.04 \%$

THE WT \% OF B203 IS: $20.00 \%$

THE WT \% OF CAO IS: $1.18 \%$

THE WT \% OF CR203 IS: .50\%

THE WT \% OF FE203 IS: $4.28 \%$

THE WT \% OF LI20 IS: $5.84 \%$

THE WT \% OF MGO IS: .24\%

THE WT \% OF NA20 IS: $5.00 \%$

THE WT \% OF P205 IS: $.22 \%$

THE WT \% OF SIO2 IS: $57.00 \%$

THE WT \% OF U03 IS: $.00 \%$

THE WT \% OF ZR02 IS: .07\%

THE WT \% OF AL203 + ZRO2 IS:

THE WT \% OF AL203 + FE203 + ZRO2 IS: $6.40 \%$

THE WT \% OF CAO + MGO IS: $1.42 \%$

THE WT \% OF RH203 + RU203 IS:

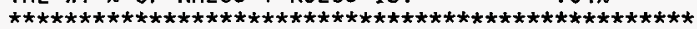

THE HL WASTE OXIDE LOADING IS: $18.1 \%$

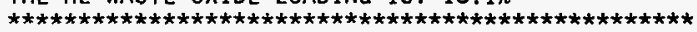

THE WT \% OF AL203 IN THE FRIT IS: .00\%

THE WT \% OF B203 IN THE FRIT IS: $24.38 \%$

THE WT \% OF FE203 IN THE FRIT IS: $.00 \%$

THE WT \% OF LI20 IN THE FRIT IS: $7.12 \%$

THE WT \% OF NA20 IN THE FRIT IS: $1.62 \%$

THE WT \% OF SIO2 IN THE FRIT IS: $66.88 \%$

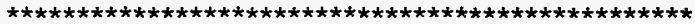

THIS PRODUCES $358.90 .62-M^{\wedge} 3$ HLW CANISTERS

THIS PRODUCES $176.6 \quad 1.26-M^{\wedge} 3$ HLW CANISTERS

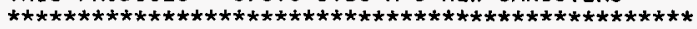

THE HLW GLASS IS CR203 LIMITED.

THIS SIMULATION WAS RUN USING CVS LIMITS AND

GLASS FORMERS.

ENHANCED IN-TANK SLUDGE WASHING IS FOLLOWED BY

THREE DILUTE CAUSTIC WASHES.

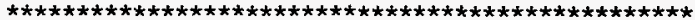


WHC-SD-WM-ES-386

Revision 0

TRU Waste Volume Projections (Rev. 2) - High Temperature HLW Glass Formulation

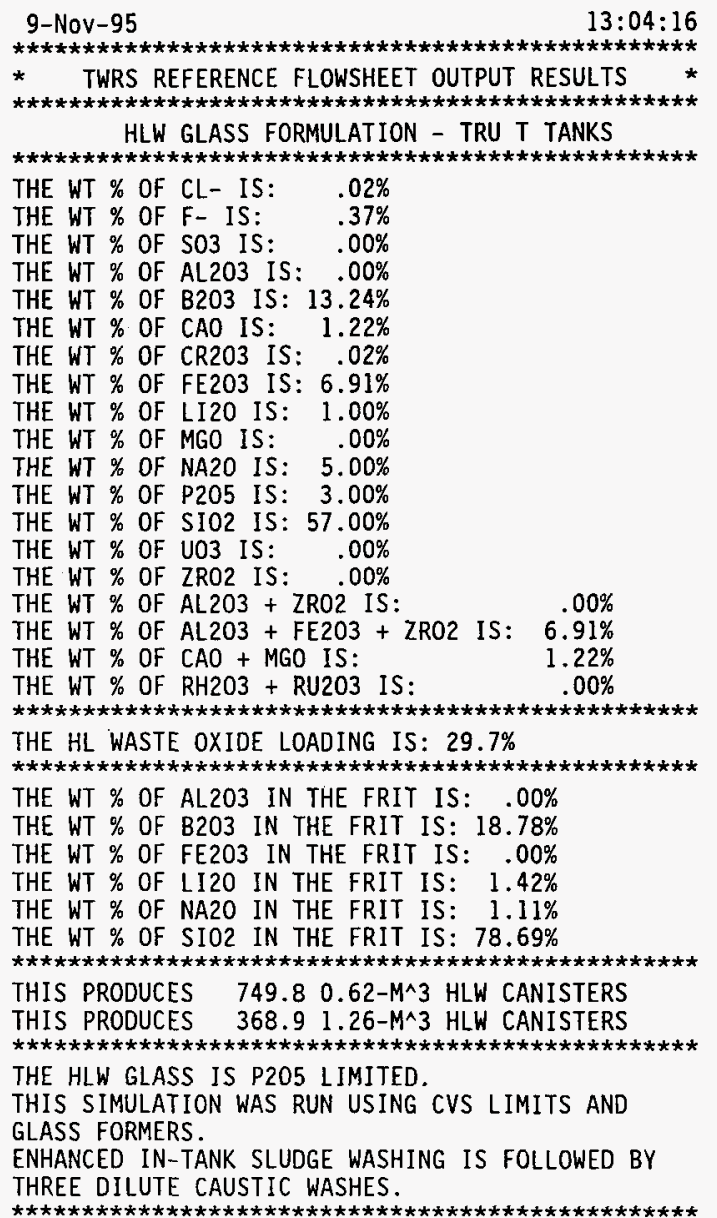


TRU Waste Volume Projections (Rev. 2) - High Temperature HLW Glass Formulation (Lower Limits Only) 
TRU Waste Volume Projections (Rev. 2) - High Temperature HLW Glass Formulation (Lower Limits Only)

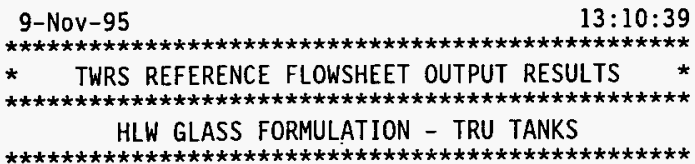

THE WT $\%$ OF CL- IS: $.01 \%$

THE WT \% OF F- IS: $1.17 \%$

THE WT $\%$ OF S03 IS: $.03 \%$

THE WT $\%$ OF AL203 IS: $.98 \%$

THE WT \% OF B203 IS: $5.00 \%$

THE WT \% OF CAO IS: $1.20 \%$

THE WT \% OF CR203 IS: $.19 \%$

THE WT \% OF FE203 IS: $5.56 \%$

THE WT \% OF LI20 IS: $1.00 \%$

THE WT $\%$ OF MGO IS: $.07 \%$

THE WT \% OF NA20 IS: $12.57 \%$

THE WT \% OF P205 IS: $1.89 \%$

THE WT \% OF SI02 IS: $42.00 \%$

THE WT $\%$ OF U03 IS: $1.50 \%$

THE WT \% OF ZRO2 IS: $16.89 \%$

THE WT \% OF AL203 + ZR02 IS: $17.87 \%$

THE WT \% OF AL2O3 + FE203 + ZRO2 IS: $23.44 \%$

THE WT $\%$ OF CAO + MGO IS: $1.27 \%$

THE WT $\%$ OF RH2O3 + RU203 IS: .01\%

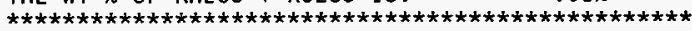

THE HL WASTE OXIDE LOADING IS: $54.6 \%$

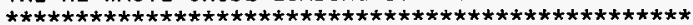

THE WT \% OF AL203 IN THE FRIT IS: .00\%

THE WT \% OF B203 IN THE FRIT IS: $10.99 \%$

THE WT \% OF FE203 IN THE FRIT IS: $.00 \%$

THE WT \% OF LI2O IN THE FRIT IS: $2.20 \%$

THE WT $\%$ OF NA2O IN THE FRIT IS: $.00 \%$

THE WT \% OF S102 IN THE FRIT IS: $86.81 \%$

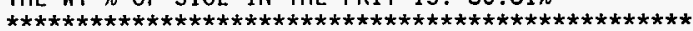

THIS PRODUCES 1238.3 0.62-M^3 HLW CANISTERS

THIS PRODUCES $609.31 .26-M^{\wedge} 3$ HLW CANISTERS

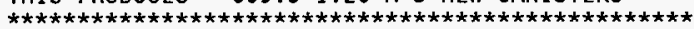

THE HLW GLASS IS FRIT LIMITED.

THIS SIMULATION WAS RUN USING CVS LIMITS AND

GLASS FORMERS.

ENHANCED IN-TANK SLUDGE WASHING IS FOLLOWED BY

THREE DILUTE CAUSTIC WASHES.

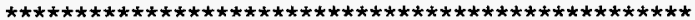




\section{WHC-SD-WM-ES-386}

\section{Revision 0}

TRU Waste Volume Projections (Rev. 2) - High Temperature HLW Glass Formulation (Lower Limits Only)

9-Nov-95

$13: 40: 54$

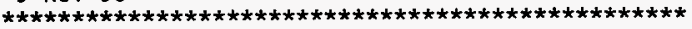

TWRS REFERENCE FLOWSHEET OUTPUT RESULTS

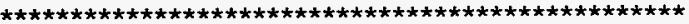

HLW GLASS FORMULATION - REMAINING TANKS

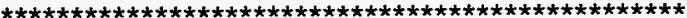

THE WT \% OF CL- IS: $\quad .05 \%$

THE WT \% OF F- IS: $\quad .26 \%$

THE WT \% OF S03 IS: $\quad .06 \%$

THE WT \% OF AL2O3 IS: $12.43 \%$

THE WT \% OF B203 IS: $5.00 \%$

THE WT \% OF CAO IS: $.94 \%$

THE WT \% OF CR203 IS: $.46 \%$

THE WT \% OF FE203 IS: $5.38 \%$

THE WT \% OF LI2O IS: $1.00 \%$

THE WT \% OF MGO IS: $.00 \%$

THE WT \% OF NA2O IS: $12.78 \%$

THE WT \% OF P205 IS: $1.89 \%$

THE WT \% OF SIO2 IS: $42.00 \%$

THE WT \% OF U03 IS: $8.87 \%$

THE WT \% OF ZR02 IS: $3.18 \%$

THE WT \% OF AL203 + ZRO2 IS: $15.62 \%$

THE WT \% OF AL203 + FE203 + ZR02 IS: $20.99 \%$

THE WT \% OF CAO + MGO IS: $\quad .94 \%$

THE WT \% OF RH203 + RU203 IS: .00\%

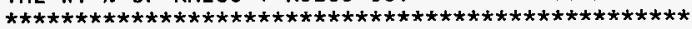

THE HL WASTE OXIDE LOADING IS: $59.8 \%$

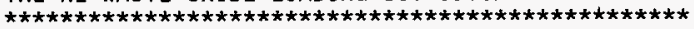

THE WT \% OF AL203 IN THE FRIT IS: $.00 \%$

THE WT \% OF B203 IN THE FRIT IS: $12.41 \%$

THE WT \% OF FE203 IN THE FRIT IS: $.00 \%$

THE WT \% OF LI20 IN THE FRIT IS: $2.48 \%$

THE WT \% OF NA20 IN THE FRIT IS: $.00 \%$

THE WT \% OF SIO2 IN THE FRIT IS: $85.11 \%$

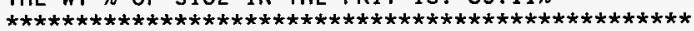

THIS PRODUCES $10815.10 .62-M^{\wedge} 3$ HLW CANISTERS

THIS PRODUCES $5321.7 \quad 1.26-M^{\wedge} 3$ HLW CANISTERS

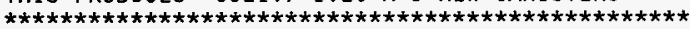

THE HLW GLASS IS FRIT LIMITED.

THIS SIMULATION WAS RUN USING CVS LIMITS AND

GLASS FORMERS.

ENHANCED IN-TANK SLUDGE WASHING IS FOLLOWED BY

THREE DILUTE CAUSTIC WASHES.

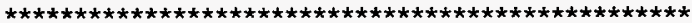


WHC-SD-WM-ES-386

Revision 0

TRU Waste Volume Projections (Rev. 2) - High Temperature HLW Glass Formulation (Lower Limits Only)

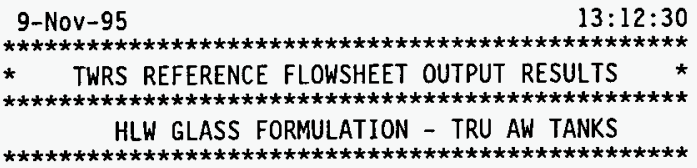

THE WT \% OF CL- IS: $\quad .00 \%$

THE WT $\%$ OF F- IS: $1.56 \%$

THE WT $\%$ OF SO3 IS: $\quad .04 \%$

THE WT \% OF AL203 IS: $.64 \%$

THE WT \% OF B203 IS: $5.00 \%$

THE WT \% OF CAO IS: $.20 \%$

THE WT \% OF CR203 IS: $.05 \%$

THE WT \% OF FE203 IS: $2.00 \%$

THE WT \% OF LI20 IS: $1.00 \%$

THE WT \% OF MGO IS: $.00 \%$

THE WT $\%$ OF NA20 IS: $14.76 \%$

THE WT \% OF P205 IS: $.01 \%$

THE WT $\%$ OF SIO2 IS: $42.00 \%$

THE WT \% OF U03 IS: $2.48 \%$

THE WT \% OF ZRO2 IS: $27.80 \%$

THE WT \% OF AL203 + ZRO2 IS: $28.44 \%$

THE WT \% OF AL203 + FE203 + ZR02 IS: $30.44 \%$

THE WT \% OF CAO + MGO IS: $.20 \%$

THE WT \% OF RH203 + RU203 IS: .00\%

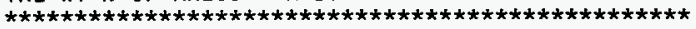

THE HL WASTE OXIDE LOADING IS: $51.9 \%$

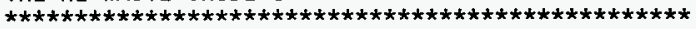

THE WT \% OF AL203 IN THE FRIT IS: .00\%

THE WT \% OF B203 IN THE FRIT IS: $10.38 \%$

THE WT \% OF FE203 IN THE FRIT IS: $3.70 \%$

THE WT \% OF LI20 IN THE FRIT IS: $2.08 \%$

THE WT \% OF NA20 IN THE FRIT IS: $.00 \%$

THE WT \% OF SIO2 IN THE FRIT IS: $83.85 \%$

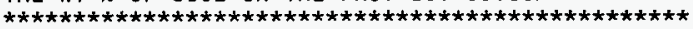

THIS PRODUCES 751.0 0.62-M^3 HLW CANISTERS

THIS PRODUCES $369.51 .26-M^{\wedge} 3$ HLW CANISTERS

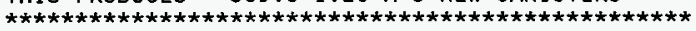

THE HLW GLASS IS FRIT LIMITED.

THIS SIMULATION WAS RUN USING CVS LIMITS AND

GLASS FORMERS.

ENHANCED IN-TANK SLUDGE WASHING IS FOLLOWED BY THREE DILUTE CAUSTIC WASHES.

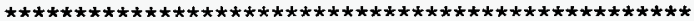


WHC-SD-WM-ES-386

Revision 0

TRU Waste Volume Projections (Rev. 2) - High Temperature HLW Glass Formulation (Lower Limits Only)

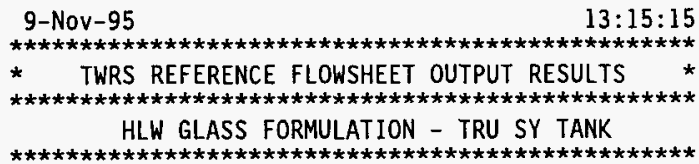

THE WT \% OF CL- IS: $.01 \%$

THE WT \% OF F- IS: $.01 \%$

THE WT \% OF 503 IS: $.01 \%$

THE WT \% OF AL203 IS: $6.71 \%$

THE WT \% OF B203 IS: $5.00 \%$

THE WT \% OF CAO IS: $3.86 \%$

THE WT \% OF CR203 IS: $1.64 \%$

THE WT \% OF FE203 IS: $14.07 \%$

THE WT \% OF LI20 IS: $1.00 \%$

THE WT \% OF MGO IS: $.79 \%$

THE WT \% OF NA2O IS: $12.07 \%$

THE WT \% OF P205 IS: $.72 \%$

THE WT \% OF SIO2 IS: $42.00 \%$

THE WT \% OF U03 IS: $.00 \%$

THE WT \% OF ZR02 IS: $.24 \%$

THE WT \% OF AL203 + ZRO2 IS: $\quad 6.95 \%$

THE WT \% OF AL203 + FE203 + ZR02 IS: $21.02 \%$

THE WT \% OF CAO + MGO IS: $4.65 \%$

THE WT \% OF RH203 + RU203 IS: .13\%

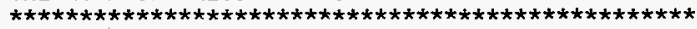

THE HL WASTE OXIDE LOADING IS: $59.1 \%$

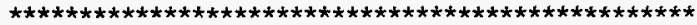

THE WT \% OF AL203 IN THE FRIT IS: $.00 \%$

THE WT \% OF B203 IN THE FRIT IS: $12.20 \%$

THE WT \% OF FE203 IN THE FRIT IS: $.00 \%$

THE WT \% OF LI20 IN THE FRIT IS: $2.44 \%$

THE WT \% OF NA2O IN THE FRIT IS: .00\%

THE WT \% OF SI02 IN THE FRIT IS: $85.36 \%$

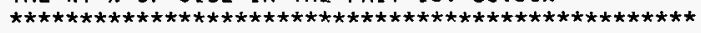

THIS PRODUCES $109.30 .62-M^{\wedge} 3$ HLW CANISTERS

THIS PRODUCES $53.81 .26-M^{\wedge} 3$ HLW CANISTERS

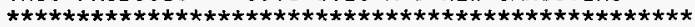

THE HLW GLASS IS FRIT LIMITED.

THIS SIMULATION WAS RUN USING CVS LIMITS AND

GLASS FORMERS.

ENHANCED IN-TANK SLUOGE WASHING IS FOLLOWED BY

THREE DILUTE CAUSTIC WASHES.

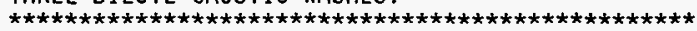


WHC-SD-WM-ES-386

Revision 0

TRU Waste Volume Projections (Rev. 2) - High Temperature HLW Glass Formulation (Lower Limits Only)

\footnotetext{
$13: 18: 01$

9-Nov-95

13.18 .01

* TWRS REFERENCE FLOWSHEET OUTPUT RESULTS *

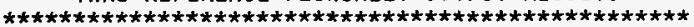

HLW GLASS FORMULATION - TRU T TANKS

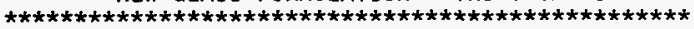

THE WT \% OF CL- IS: $.03 \%$

THE WT \% OF F- IS: $.69 \%$

THE WT $\%$ OF S03 IS: $.01 \%$

THE WT \% OF AL203 IS: $.00 \%$

THE WT \% OF B203 IS: $5.00 \%$

THE WT \% OF CAO IS: $2.26 \%$

THE WT \% OF CR203 IS: $.04 \%$

THE WT \% OF FE203 IS: $12.84 \%$

THE WT \% OF LI20 IS: $1.00 \%$

THE WT \% OF MGO IS: $.00 \%$

THE WT \% OF NA2O IS: $7.84 \%$

THE WT \% OF P205 IS: $5.58 \%$

THE WT \% OF SI02 IS: $42.00 \%$

THE WT \% OF U03 IS: $.01 \%$

THE WT \% OF ZRO2 IS: .00\%

THE WT \% OF AL203 + ZR02 IS: $.00 \%$

THE WT \% OF AL203 + FE203 + ZR02 IS: $12.84 \%$

THE WT \% OF CAO + MGO IS: $2.26 \%$

THE WT \% OF RH203 + RU203 IS: $\quad .00 \%$

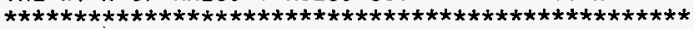

THE HL WASTE OXIDE LOADING IS: $54.9 \%$

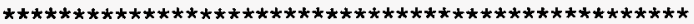

THE WT \% OF AL203 IN THE FRIT IS: .00\%

THE WT \% OF B203 IN THE FRIT IS: $11.07 \%$

THE WT $\%$ OF FE203 IN THE FRIT IS: $.00 \%$

THE WT \% OF LI20 IN THE FRIT IS: $2.21 \%$

THE WT $\%$ OF NA20 IN THE FRIT IS: $.00 \%$

THE WT $\%$ OF SIO2 IN THE FRIT IS: $86.71 \%$

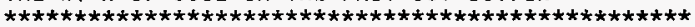

THIS PRODUCES 403.4 0.62-M^3 HLW CANISTERS

THIS PRODUCES $198.51 .26-M^{\wedge} 3 \mathrm{HLW}$ CANISTERS

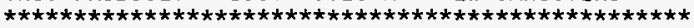

THE HLW GLASS IS FRIT LIMITED.

THIS SIMULATION WAS RUN USING CVS LIMITS AND

GLASS FORMERS.

ENHANCED IN-TANK SLUDGE WASHING IS FOLLOWED BY

THREE DILUTE CAUSTIC WASHES.

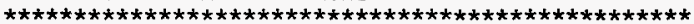


WHC-SD-WM-ES-386

Revision 0

APPENDIX B

DRAWING ES-ALT3X-01

HIGH-LEVEL WASTE 20 MT/DAY STANDALONE WITH JOULE-HEATED MELTER 
WHC-SD-WM-ES-386

Revision 0

This page intentionally left blank.

B-2 


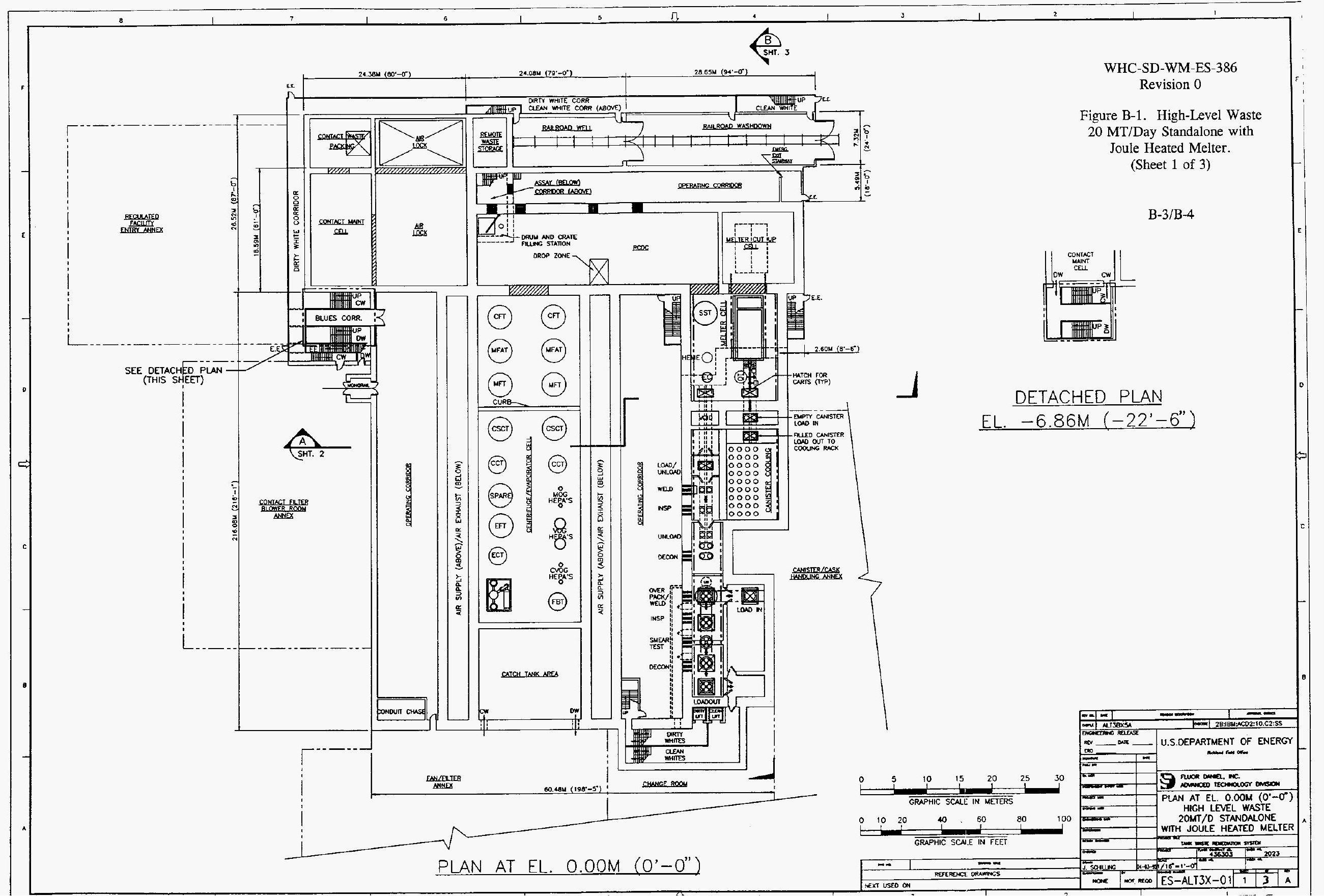


WHC-SD-WM-ES-386 Revision 0

Figure B-1. High-Level Waste 20 MT/Day Standalone with

Joule Heated Melter. (Sheet 2 of 3 )

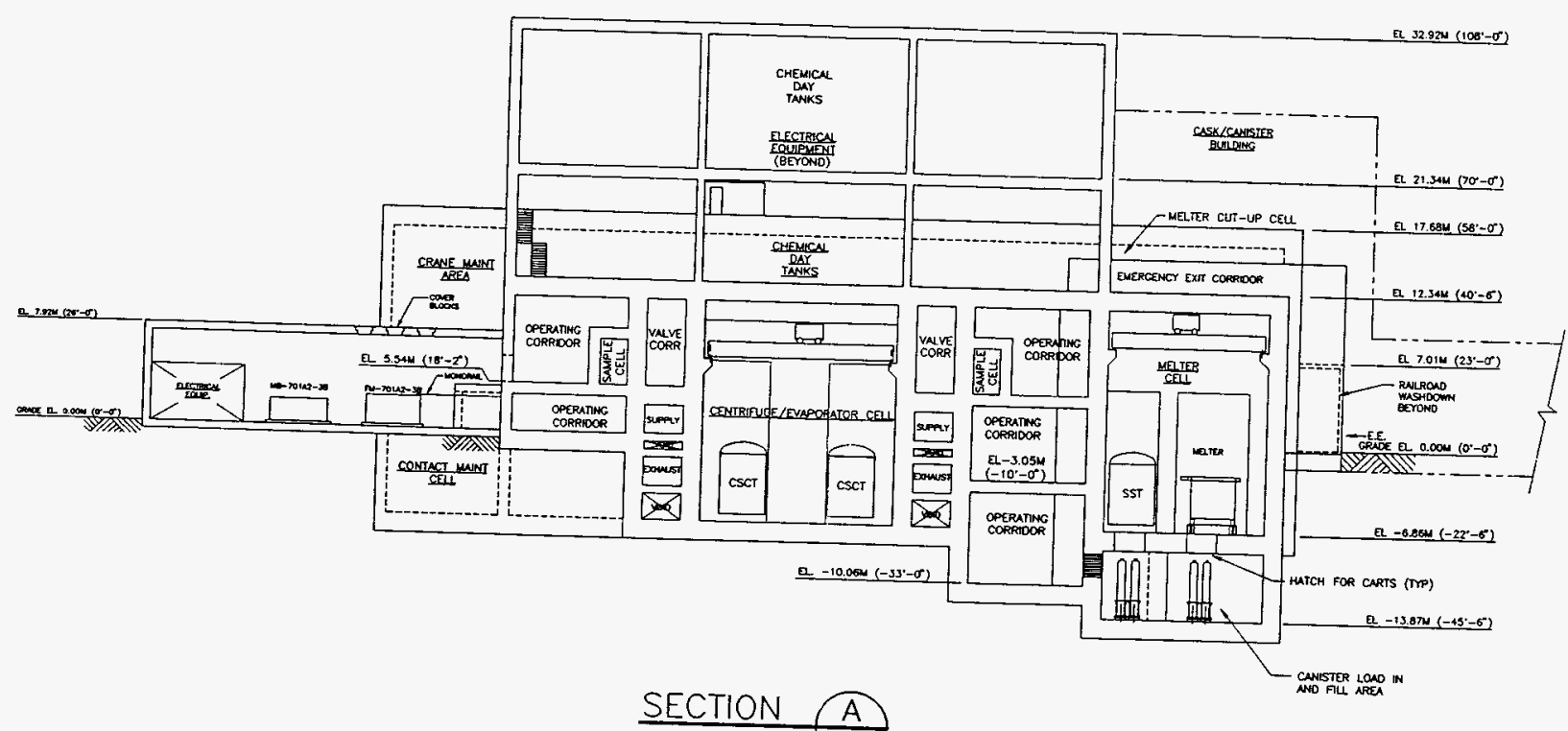

B-5/B-6

SHT. $1 \& 2$

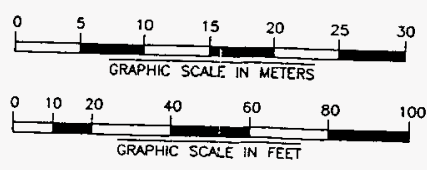

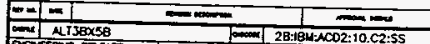
U.S.DEPARTMENT OF ENERGY

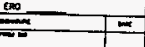
TENT OF

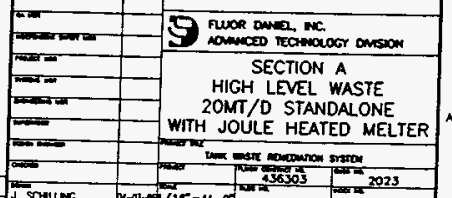




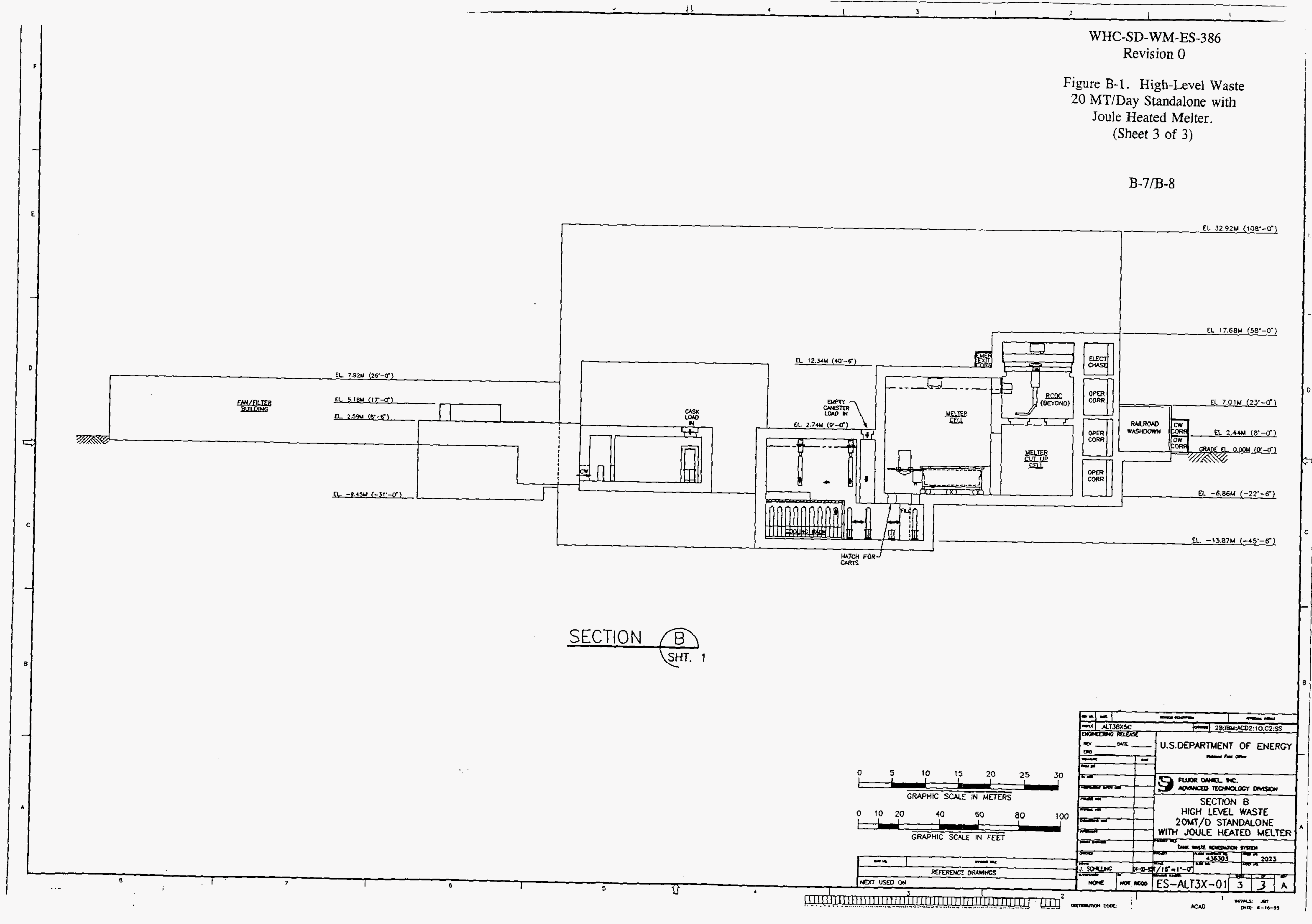


WHC-SD-WM-ES-386

Revision 0

APPENDIX C

TRANSURANIC WASTE DISPOSAL AT

WASTE ISOLATION PILOT PLANT

C-1 
WHC-SD-WM-ES-386

Revision 0

This page intentionally left blank.

C-2 
WHC-SD-WM-ES-386

Revision 0

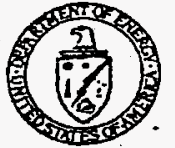

Kr. Jack Schultz

Senior Evaluator

U.S. Government Accounting Office.

Roon E-172

U.S. Department of Energy

Kashington, D.C. 20585-0002

Dear Mr. Schultz:

As you indicated in previous telephone conversations with my staff, the General Accounting office is evaluating alternatives for the management of Rocky Flats Plant residues. One such alternative being discussed, as I understand, is declaring the residues transuranic (TRU) waste and disposing then in the Waste Isolation Pllot Plant (WIPP).

To support your evaluation, you requested an estimate of the cost to dispose of a cantainer of TRU waste at UIPP. Attachment 1 is a rough order-ofmagnitude estimate of the UIPP life-cycle costs developed by my staff. This information was used to deternine the cost information you requested. As you can see, the cost to dispose of one contilner of TRU raste at HIPP is approximately $\$ 7,000$. The assumptions used to develop this estimate are shom In Attachment 2.

For comparison, the life-cycle disposal cost of a container of high-level waste on an equivalent volume basis is approximately $\$ 100,000$. This information was extracted from Department of Energy (DOE) pubification DOE/RU. 0295P, Prelininary Estimates of the Total-5ystea Cost for the Restructured Program, dated December 1990. You should contact the office of Civilian Radioactive Kaste Hanagement if you are interested in high-level waste disposal costs.

If you. have*any questions, please contact Ed Vade of ay staff on 903-7207.

$$
\text { Sincerely, }
$$

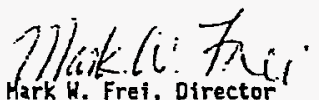$$
\text { Office of Kaste Kanagenent Projects }
$$$$
\text { Office of Haste Hanagement }
$$$$
\text { Environgental Restoration }
$$
and Kaste Kanagement

2 Attachments

cc $r /$ attachments:

C. Conner, RU-133

J. Rhoderick, EH-351

P. Bubar, EH-323

J. Arthur, KPIO

A. Hunt, HPSO

G. Daly, BDH 
WHC-SD-WM-ES-386

Revision 0

Attichment" 1

APRIL 22, 1992

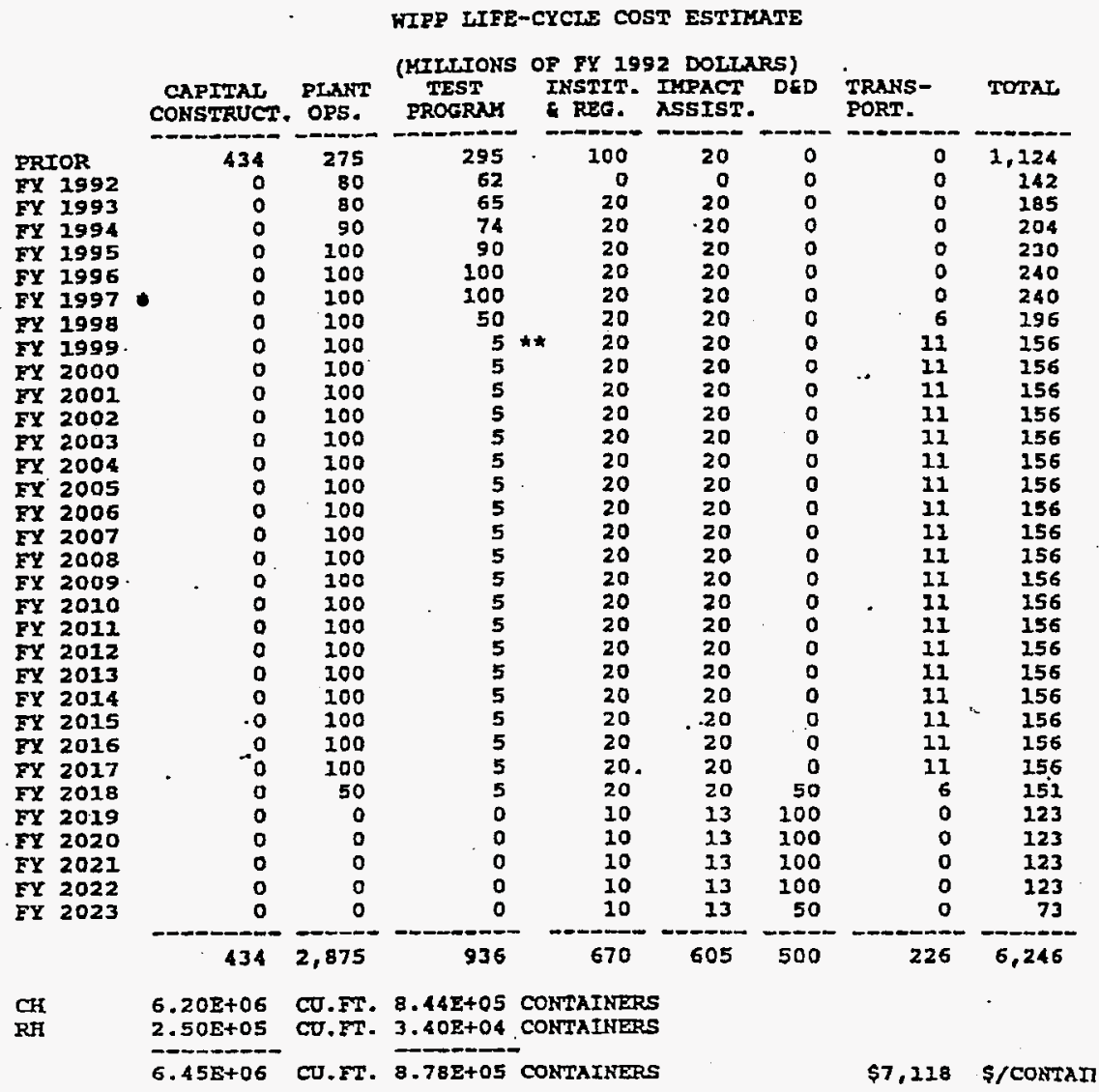

* Disposal decision made in 12/97

* * Performance confirmation costs begin in FY 1999 
WHC-SD-WM-ES-386

Revision 0

Attachoent 2

April 22, 1992

\section{VIPP COHTAIHER COST ESTIMATE ASSUMPTIOHS}

- Prior year costs for Capital Construction represent the actual total estimated cost (TEC) of the project.

- Prior year costs for Capital Construction and Plant Operations represent the aetual total project cost (TPC) of the project.

- The FY 1992 costs are consistent with the current FY 1992 appropriation.

- The EY 1993 costs are consistent with the pending Congressional budget request.

- The FY 1994 and out-year costs are planning levels, which are subject to change.

- The Test Phase with radioactive waste begins in FY I992 and continues into FY 1998.

- The Disposal Phase is 20 years in duration, beginning in FY 1998 and continuing into FY 2018. It is assumed that the decision on WIPP's suitability for disposal is made in lecember-1997.

- Decontamination and Decomissioning will occur during a five year period following the Disposal Phase, beginning in 2018.

- Test Program costs from FY 1999 through FY 2018 are for a performance confirmation progran.

- Institutional and Regulatory costs include DOE oversight and integration, support of external revfew groups, emergency preparedness, regulators, and public outreach.

- Impact assistance costs, consistent uith provisions of S. 1671, are payments to Nex Hexico to cover impacts from KIPP operations.

- Costs for shipping waste to KIPP for disposal are included. These costs include amortized costs for additional TRUPACT-IIs.

- The total cost does not inciude any waste characterization or treatment costs performed by generator sites prior to shipment for disposal.

- The quantity of waste containers (drum equivalents) is equal to the KIPP design capacity for contact-handled (CH) and remote-handled (RH) waste. 
WHC-SD-WM-ES-386

Revision 0

This page intentionally left blank. 
DISTRIBUTION SHEET

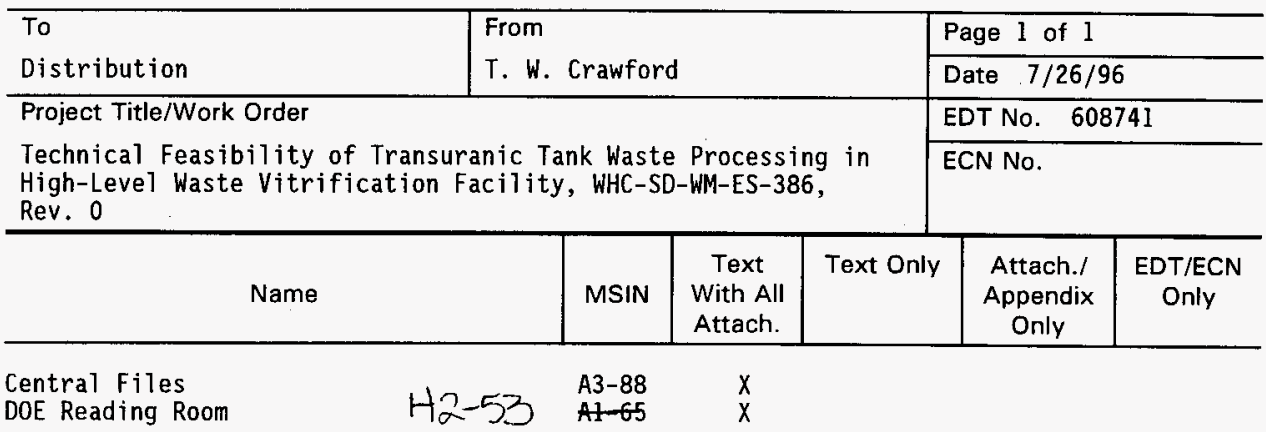

U.S. Department of Energy-Richland Operations Office

$\begin{array}{lll}\text { C. P. Bader } & \text { S7-50 } & X \\ \text { D. D. Button } & K 6-51 & X \\ \text { R. Carreon } & K 6-51 & X \\ \text { R. A. Gilbert } & K 6-51 & X \\ \text { J. K. McClusky } & S 7-54 & X \\ \text { W. J. Taylor } & K 6-51 & X \\ \text { H. J. Wacek } & S 7-54 & X \\ \text { D. D. Wodrich } & S 7-50 & X\end{array}$

Westinghouse Hanford Company

A. L. Boldt

R. D. Claghorn

R. P. Colburn

T. W. Crawford

J. S. Garfield

R. L. Gibby

E. J. Kosiancic

S. L. Lambert

A. F. Manuel (3)

C. M. McConvilile

R. M. Orme

R. W. Powell

E. M. Randkleve

P. S. Schaus

ICF Kaiser Hanford S. K. Baker
H5- 49

H5- 49

H5-27

H5-49

H5-49

H5-27

H5-61

H5-27

H5-49

H5- 49

H5-27

H4- 14

H5-27

G3-21

$X$
$X$
$X$
$X$
$X$
$X$
$X$
$X$
$X$
$X$
$X$
$X$
$X$
$X$

H5-49 X 